Notre Dame Law Review

Volume 78 | Issue 4

Article 5

5-1-2003

\title{
The Metamorphoses of Reasonable Doubt: How Changes in the Burden of Proof Have Weakened the Presumption of Innocence
}

Steve Sheppard

Follow this and additional works at: http://scholarship.law.nd.edu/ndlr

\section{Recommended Citation}

Steve Sheppard, The Metamorphoses of Reasonable Doubt: How Changes in the Burden of Proof Have Weakened the Presumption of Innocence, 78 Notre Dame L. Rev. 1165 (2003).

Available at: http://scholarship.law.nd.edu/ndlr/vol78/iss4/5

This Article is brought to you for free and open access by NDLScholarship. It has been accepted for inclusion in Notre Dame Law Review by an authorized administrator of NDLScholarship. For more information, please contact lawdr@nd.edu. 


\title{
THE METAMORPHOSES OF REASONABLE DOUBT: HOW CHANGES IN THE BURDEN OF PROOF \\ HAVE WEAKENED THE PRESUMPTION \\ OF INNOCENCE
}

\begin{abstract}
Steve Sheppard*
Words change their meanings in ways that trap the historically unwary. ${ }^{1}$
\end{abstract}

I. Before the Eighteenth Century: Convictions vs.

Doubts.............................. 1170

II. The Seventelenth Through the Nineteenth Centuries:

The Standard Arises-Moral Certainty and Reasonable

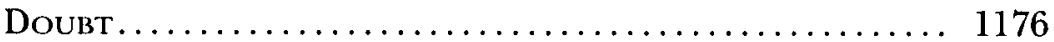

A. Moral Certainty ........................ 1176

B. Bishop Wilkins, Moral Certainty, and Reasonable Doubt ... 1178

C. Moral Certainty and the Law .................. 1180

D. Reasonableness of the Juror's Doubts ............. 1183

* Associate Professor, University of Arkansas School of Law. I am grateful for the comments of Steve Bibas, Marius Bolten, Russell Christopher, Martin Flaherty, George Fletcher, Philip Hamburger, Alon Harel, Dick Helmholz, Kyron Huigens, Ed Imwinkelreid, Don Judges, Mark Killenbeck, William Nelson, Ed Rubin, Pierre Schlag, and Jeremy Waldron on various sketches of this paper, and for the criticism of the University of Chicago Legal History Workshop, the Columbia Law School Seminar in Criminal Theory, the Colloquium in Legal History at New York University, and the Works in Progress panel at the University of Arkansas. This Article could not have been completed without the assistance of my student Blake Rutherford, and of Glen-Peter Ahlers, David Gay, and the staff of the University of Arkansas Law Library, or of Kent McKeever, Whitney Bagnall, and the staff of the Diamond Law Library at Columbia. My thanks, especially, to George, from whom I nicked the title.

This Article is dedicated with respect to the two mentors whose care, guidance, and example have benefited not only me but my students more than they will know, the Honorable E. Grady Jolly, Jr., and the Honorable William Barbour, Jr., in recognition of their twenty years of service on the benches, respectively, of the U.S. Court of Appeals for the Fifth Circuit and the U.S. District Court for the Southern District of Mississippi.

1 Christopher Hill, "Reason" and "Reasonableness" in Seventeenth-Century England, 20 BRit. J. Soc. 235, 236 (1969). 
III. The Merger of Reasonable Doubt and Moral Certainty ....................................... 1195

IV. The Nineteenth and Twentieth Centuries: Reasonable Doubt Becomes Articulable Doubt............... 1204

A. Reasonable Doubts Become Specific and Articulable Doubts . 1206

B. Articulability Encouraged by the Pressure of the Advocates and by Confusion with Other Rules ................ 1214

V. The Twentieth Gentury: Reasonable Doubt

Enshrined-Or Petrified....................... 1216

A. Reasonable Doubt Becomes Constitutionally Enshrined, and Moral Certainty Takes a Beating ................ 1217

B. The Difficulties of Articulability Continue............. 1223

C. Articulable Doubt and the Presumption of Innocence ...... 1226

VI. Twentieth and Twenty-First Centuries: Doubts About

REasonable Doubt ....................... 1227

A. Wigmoreans and the Instruction ................ 1228

B. The Multiplicity of Meanings for Reasonable Doubt I: As Judgment of a Reasonable Juror ................ 1231

C. The Multiplicity of Meanings for Reasonable Doubt II: As a Modifier of Doubts ........................ 1233

D. As a Contingent View of Judgment, Reasonableness Is Controversial.............................. 1234

E. Articulable Reasonableness and the Presumption of Innocence 1237

VII. Conclusions and Further Considerations ............ 1239

A. The Significance of Reasonable-Doubt Instructions Has Changed............................. 1239

B. The Change May Fundamentally Alter the Presumption of Innocence............................. 1239

C. The Instruction Intrudes on Juror Discretion .......... 1240

D. There Is a Need for Further Empirical Research ........... 1244

Appendix: Sample: Model Jury Instructions $1999 \ldots \ldots \ldots \ldots \ldots .1246$

The standard of criminal proof beyond a reasonable doubt is believed almost everywhere to be a bulwark of protection for the accused, an assurance that the state will not punish the innocent to snare more easily the guilty. A popular icon of the law generally, ${ }^{2}$ it is

2 Indeed, the term has not only thickened the plot but broadcast the title of several popular books lately. See, e.g., Jeffrey Archer, Beyond Rizasonable Doubt (1994); Philla Friedman, Reasonable Doubt (1990); Toby Marlowe, Beyond a Reasonable Doubs (1997). One of director Fritz Lang's last films was Beyond A REAsonAliLE DOUBT (RKO 1956). 
thought to be one of the glories of the common law. ${ }^{3}$ It is often believed to help ensure that the prosecution has the burden of persuasion, by which the state must prove the defendant's guilt and the defendant is presumed innocent. ${ }^{4}$ These beliefs, however, do not assay well against the touchstone of history.

A great many scholars have been drawn to study the instruction, to examine both its operation, particularly whether jurors are accu-

3 Many are the paeans to reasonable doubt. See, for example, those collected in Scott Sundby, The Reasonable Doubt Rule and the Meaning of Innocence, 40 HaSTINGs L.J. $457,457-62$ (1989). None have been as significant to American criminal law as those raised thirty years ago, when the U.S. Supreme Court adopted a constitutional requirement that juries find proof of guilt beyond a reasonable doubt. Justice Brennan then wrote,

The requirement that guilt of a criminal charge be established by proof beyond a reasonable doubt dates at least from our early years as a Nation.....

The reasonable-doubt standard plays a vital role in the American scheme of criminal procedure. It is a prime instrument for reducing the risk of convictions resting on factual error. The standard provides concrete substance for the presumption of innocence-that bedrock "axiomatic and elementary" principle whose "enforcement lies at the foundation of the administration of our criminal law."

In re Winship, 397 U.S. 358, 361-63 (1970) (citations omitted); see also infra Part IV. Such sentiments have led to the international spread of the standard as a rule of law. See, e.g., Article 66 of the Rome Statute of the International Criminal Court, U.N. Doc. A/ CONF.183/9 (as of July 17, 1998), available at http://www.un.org/law/icc/statute/ romefra.htm. Article 66 provides:

1. Everyone shall be presumed innocent until proved guilty before the Court in accordance with the applicable law.

2. The onus is on the Prosecutor to prove the guilt of the accused.

3. In order to convict the accused, the Court must be convinced of the guilt of the accused beyond reasonable doubt.

4 There is a necessary interrelationship between the burden of proof and burden of persuasion in any argument, much less a legal argument or criminal trial. Thus, such statements are often made hand in glove, as in Justice Frankfurter's claim that

[f] rom the time that the law which we have inherited has emerged from dark and barbaric times, the conception of justice which has dominated our criminal law has refused to put an accused at the hazard of punishment if he fails to remove every reasonable doubt of his innocence in the minds of jurors. It is the duty of the Government to establish his guilt beyond a reasonable doubt. This notion-basic in our law and rightly one of the boasts of a free society-is a requirement and a safeguard of due process of law in the historic, procedural content of "due process." Accordingly there can be no doubt, I repeat, that a State cannot cast upon an accused the duty of establishing beyond a reasonable doubt that his was not the act which caused the death of another.

Leland v. Oregon, 343 U.S. 790, 802-03 (1952) (Frankfurter, J., dissenting); see also infra Part VI.E. 
rately applying its confusing and varied formulations, and its essence, particularly whether the instruction sufficiently protects the accused.5 None of their works, however, have considered fully the implications of the historical development of variations among the instructions upon the role of the juror or upon the function of the presumption of innocence. As a result, despite this frequency of academic consideration, the outstanding variation of the instruction in the twentieth century, defining reasonable doubt as a doubt for which a reason can be given, has received little consideration from the academy. ${ }^{6}$

This Article, therefore, presents a brief history of the instruction with emphasis on these points and one other. Historians have examined the origins of the doctrine, its antecedents in seventeenthcentury England and its use in eighteenth-century common-law courts. ${ }^{7}$ The standard's evolution after 1850 and the significance of

5 For recent discussions, see, for example, Henry L. Chambers, Jr., Reasonable Certainty and Reasonable Doubt, 81 MARQ. L. Rev. 655, 681-97 (1998) (examining the operation); Melissa Corwin, Defining "Proof Beyond a Reasonable Doubt" for the Criminal Jury: The Third Circuit Accepts an Invitation To Tolerate Constitutionally Inadequate Phraseolngy, 46 VILL. L. Rev. 829, 833-43 (2001) (examining the operation); Stephen J. Fortunato, Jr., Instructing on Reasonable Doubl After Victor v. Nebraska: A Trial Judge's Certain Thoughls on Certainty, 41 VILL. L. Rev. 365, 378-429 (1996) (examining both essence and operation); Lawrence V. Johnston III, The Instruction on Reasonable Doubt: 200 Years of Sophistry Is Enough, 72 FLA. B.J. 61, 61 (1998) (examining the operation); Thomas V. Mulrine, Reasonable Doubt: How in the World Is It Defined? 12 AM. U. J. INT'L L. \& PoL'Y 195, 199-210 (1997) (examining both essence and operation); Timothy P: O'Neill, Instructing Illinois Juries on the Definition of "Reasonable Doubt": The Need For Reform, 27 Lov. U. CHI. L.J. 921, 924-54 (1996) (examining the operation); Lawrence M. Solan, Refocusing the Burden of Proof in Criminal Cases: Some Doubt About Reasonable Doubt, 78 Tex. L. Rev. 105, 109-32 (1999) (examining the essence); Elisabeth Stoffelmayr \& Shari Seidman Diamond, The Conflict Between Precision and Flexibility in Explaining "Beyond a Reasonable Doubt", 6 PsychOL. PuB. PoL'y \& L. 769, 777 (2000) (examining the essence); Colin Moran, Note, Cardinal Newman and Jury Verdicts: Reason, Belief, and Certitude, 8 YALE J.L. \& Human. 63, 72-90 (1996) (examining the essence). Earlier criticism, particularly by John Wigmore, is discussed throughout the Article below.

6 One of the few of the recent scholarly inventories of reasonable-doubt instructions to consider articulable doubt is Mulrine, supra note 5, at 216-17 (considering the instruction solely as a matter of Canadian law).

7 The bulk of this work has been done by Barbara Shapiro. See Barbara J. Shiapiro, "Beyond Reasonable Doubt" and "Probable Cause: Historical. Perspectives on the Anclo-American Law of Evidence" (1991) [hereinafter Shapiro, Beyond Reasonable Doubt]; Barbara J. Shapiro, Probability and Certainty in Seventeenth-Century England: A Study of the Relationships Between Natural Science, Religion, History, Law, and LrTerature (1983) [hereinafter Shapiro, Probability]; Barbara J. Shapiro "To a Moral Certainty": Theories of Knowledge and AngloAmerican Juries 1600-1850, 38 HASTINGs L.J. 153 (1986) [hereinafter Shapiro, Moral 
this later history upon the criminal law have remained largely unexamined. This Article seeks also to correct this omission.

A thorough consideration of the instruction since its inception reveals deep controversy, marked by four recurring arguments. First is the role of the juror; or how much independence does the law allow the juror, when the juror is exercising the seemingly independent judgment the law demands? In this question is a second, in what manner should the juror think about the evidence, or how can the juror form knowledge upon which the law will rely? From that flows a third, at what degree of certainty is the juror obliged to convict, or how thoroughly persuaded must the juror be to exercise these judgments? These three concerns are often seen only in the fourth, more visible question that arises from them: what language can express any resolution of the first three arguments, or what shall the juror be told? By considering the history of reasonable doubt with a concern for all of these issues, rather than the usual preoccupation with the language alone, several conclusions arise.

Despite its later prominence as a shield against wrongful conviction, the instruction was not devised to protect more fully the innocent. Rather it was pursued as a means of more easily convicting the accused. Toward this end, a fundamental purpose of the instruction was to constrain the juror, to prevent the juror from acting with excessive independence in determining innocence. From such dark beginnings, the manner in which these ends have been pursued has been accelerated in the light of cultural and linguistic shifts, marked especially by changes in understanding the nature and meaning of "reason." The instruction has moved from a standard incorporating three elements - $a$ form of non-metaphysical consideration, a form of moral reasoning, and a measure of sufficiency in the evidence-to being only a standard of sufficiency.

As a result of these changes, the legal consequences of the instruction have changed. Over time, the burden upon the juror who would acquit has grown, and so the evidence necessary for the state to convict has lessened. This change in the burden of proof has profound implications for the prosecutor's burden of persuasion. The new understanding of reasonable doubt can reverse the operation of the presumption of innocence.

This Article will consider in six Parts the evidence from which these conclusions are drawn:

Certainty]; see also Anthony A. Morano, A Reexamination of the Development of the Reasonable Doubt Rule, 55 B.U. L. REv. 507 (1975). 
Part I examines the juror's role prior to the advent of the reasonable-doubt instruction. Jurors enjoyed a brief period freed from the initial fetters of juror liability during which their certainty of guilt was the sole standard for their conviction of the defendant.

Part II examines the intertwined conceptions of reason, moral certainty, and doubt. During the seventeenth and eighteenth centuries, ideas of knowledge gave rise to rival conceptions of certainty, framed particularly in the writings of John Locke and Bishop John Wilkins. From these, prosecutors moved deliberately to limit the discretion of the juror.

Part III examines the development of an articulability standard, in which reasonable doubt came to mean a doubt that can be stated. This variant of the standard replaces the concept of "reasonableness" with the concept of "a reason," with grave consequences for the jury.

Part IV examines the acceptance of the burden of proof beyond a reasonable doubt as a constitutional standard in criminal cases. The controversies in applying this standard to a range of federal and state cases illustrate not only the difficulties with the standard in general but also the increasing use of the articulability standard within the constitutional framework.

Part $\mathrm{V}$ examines the academic concerns raised for a century against the instruction in general. This argument, particularly raised by the great evidence writer John Henry Wigmore, predated its constitutional acceptance, and its claims are even louder in concert with recent concerns raised against the fundamental notion that the law can or should rest on notions of reason, which are considered in Part VI.

These six Parts are, roughly, chronological. Yet they are predominately thematic, and there is a certain overlap in time as ideas are followed when they meander forward and back. The ideas themselves, and an effort to draw some conclusions from them, are presented in Part VII, in which one conclusion is a plea for more careful research, employing the tools of social science to test these conclusions.

\section{Before the Eighteenth Century: Conviction vs. Doubts}

The early days of the jury are, as they say, shrouded in mystery. ${ }^{8}$ The first jury probably rendered a decision with simple exactitude: it

8 There are institutions resembling the jury in many ancient cultures, including the Athens of Solon and the Sweden of the Sagas. The source of its import into England, at least as early as Ethelbert, is much debated. The jury lost its role in England with the Norman invasion, being replaced by trials of torture, reputation, com- 
either convicted or it did not. An early oath of the common law juror is little more than a promise to find the truth: "Hear this ye justices, that I will speak the truth concerning that which you shall question me on the king's behalf." 9 The move to require jurors to act as independent arbiters of claims with which they had no prior knowledge was an early modern innovation. ${ }^{10}$

By Edward Coke's time, the role of the common-law juror was clear and simple: "[f] or jurors are to try the fact, and the judges ought to judge according to the law that riseth upon the fact." 11 In doing so, jurors were to decide the questions of fact necessary to resolve the case, although they were specifically forbidden to attempt to decide the case on issues, usually of law, that were not within the charge before them. ${ }^{12}$ This unadorn-

bat, and other Norman means to establish guilt, usually before a noble, priest, or judge. The reintroduction of a precursor to the criminal jury began by the twelfth century, and the jury was famously required under MAGna CARTA para. 39 (1215), which required that no freeman shall be seized, or imprisoned, or dispossessed without the judgment of his peers. See John H. Baker, An Introduction to EnGlish Legal History 537 n.29 (1990). The jury contemplated in the Charters, however, only anachronistically evokes the modern criminal trial jury. See id. at 538 n.31. For the medieval development of the criminal jury, see id. at 84-90; THOMAS ANDrEw Green, Verdict According to Conscience: Perspectives on the English Criminal Trial Jury, 1200-1800 (1985); Leonard W. Levy, The Palladium of Justice: Origins of Trial by Jury (1999); and Twelve Good Men and True: The Criminal Trial Jury IN ENGLAND, 1200-1800 (J.S. Cockburn \& Thomas A. Green eds., 1988). See also WILliam Forsyth, History of Trial by Jury (1878); John Pettingal, An Inquiry into the Use of and Protection of Juries Among the Greeks and Romans (1769).

92 Fleta, bk. 1, ch. 19, at 45 (H.G. Richardson \& G.O. Sayles eds. \& trans., 72 Selden Soc'y 1995) (1647). This oath would likely have been required for a juror in what today we would call a civil case, as the oath would have been required at conviction, and not commencement, in criminal cases.

10 See sources cited supra note 7. See generally George Fisher, The Jury's Rise As Lie Detector, 107 YaLE L.J. 575, 585-602 (1997).

11 Edward Coke, First Institute of the Lawes of Eingland $\$ 366$, at *226a, reprinted in 2 The Selected Writincis of Sir Edward Coke (Steve Sheppard ed,, forthcoming 2003) (on file with author).

12 Coke's depiction of the role of the juror emphasizes the idea that still dominates rules of evidence, that the jury should only consider matters relevant to this case:

"[I]n all cases when jurors find the special matter doubtful in law pertinent and tending to the issue which they are to try, there the Court ought to accept it, but when they find matter at large which is not pertinent, . . there the Court ought to disallow it as impertinent to the issue and their charge."

Dowman's Case, 9 Coke Reports 1, 77 Eng. Rep. 743 (K.B. 1585). Doubt was also the discriminant of other procedures affecting the jury. Coke noted that the peers serving as jurors in a trial of petit treason must "if upon debate whereof they should any doubt of any matter" and desire to confer with judges, do so in open court before the 
ed view of a juror's obligations persisted into the eighteenth century. ${ }^{13}$

The decision of each juror, the mechanism by which the jurors would find the matter, was not a question for the law ${ }^{14}$ but a matter of private conscience. ${ }^{15}$ As a matter of conscience, the juror had to swear on oath to convict. From at least the late middle ages, "conviction" was the basis of a finding of guilt, and the law was based upon the jurors' conviction that the prosecutor had proved the facts asserted in the accusation. ${ }^{16}$

Looking back, it is not easy to discern the degree of proof the medieval juror expected to support a conviction. Professor John Langbein has argued that, in the absence of any evidence to deter-

prisoner. Otherwise, the peers continue together "until they are agreed of their verdict." Coke, supra note 11. The common law is not utterly consistent in maintaining the role of jurors as definers of fact alone. The provincial and colonial courts turned the whole verdict over to the jury, reserving only procedural matters, such as benefit of clergy, for the bench. See, e.g., Steve Sheppard, Paul Dutley: Heritage, Observation, and Conscience, 6 Mass. Lecal. Hist. 1, 19-22 (2000).

13 The most influential texts regarding the operation of the jury were the remarkably similar, if competing, books of Duncombe and Euer. Giles Duncombe, Tryals per Pais or, the law of Encland Concerning Juries by Nisi Prius (photo. reprint 1980) (1682); Samson Euer, Tryal.s per Pais, or, the Law, Concerning Juries by Nisi-Prius (Giles Dumcombe ed., 1986) (1665). Duncombe's was originally published in 1665 , and remained in print into the 1700 s, an updated edition being reprinted in 1725 by E. \& R. Nutt, and a ninth edition being published in Philadelphia in 1793. The obligations of the juror, in language based on Coke, were restated by DunCOMBE, supra, at 367-68 and EUER, supra, at 154-55, of finding the facts according to the evidence.

141 William Holdsworth, A History of Enclish Law 333 (1956).

15 See, e.g., John Hawles, The Enclishman's Right: A Dialogue Between a BarRISTER AT LAW AND A JURYMAN (Richard Janeway ed., London 1680) (noting among the benefits of trial by jury that all jurors "must be fully satisfied in their consciences" of guilt). Barbara Shapiro has concluded that this approach, the mere requirement that jurors, particularly in the grand jury, be "satisfied" according to their fully persuaded conscience was typical of the writers for a century. Shapiro, Bevond REAsonaBLE DouBt, supra note 7, at 13-18, $263 \mathrm{n} .50$; see also id. at 22 (citing a counsel's argument in 1777 at the Old Bailey, that "any room upon the evidence to doubt" requires a verdict of not guilty). It certainly accords with Chancellor Francis Bacon's view of scientific certainty. See, e.g., Daniel R. Coquilletre, Francis Bacon 244-56 (1992) (detailing Bacon's views of certainty in law); Sachiko Kusukawa, Bacon's Classification of Knowledge in The Cambridge Companion to Bacon 46 (Markku Peltonen ed., 1996).

16 See Act of 7 Hen. 7, c. 21. (1491) ("As though none atteyndour nor conviccion had ben hadde ageynst the seid William ....") The earliest entry in the OED for "convict" as a basis for proof of an offense is a fourteenth-century usage by Wyclif. 3 OXFORD ENGLISH DictionarY 879 (2d ed. 1989) (defining "conviction") [hereinafter OED]. 
mine what burden of proof the jurors should accept, "the trial jury required for condemnation not certainty, but only persuasion" even though jurors were often not even persuaded by the evidence they were presented. ${ }^{17}$ This conclusion, however, does not sit well with the equation of the juror's task, which was to "convict." One cannot read too much into the lexical intersection of conviction and certainty, any more than one can conclude that the jurors believed that they were personally convicting someone whom the law itself, or the judges, convicted. ${ }^{18}$

Although it is but a lexical argument, conviction seems more to be based on certainty than on mere persuasion, and the obligation upon the juror to find guilt for a conviction thus seems much more to require certainty than merely to be persuaded to some lesser degree of confidence. In the absence of any documentary evidence, the distinction that Langbein accepts that "while certainty is a much harder standard to satisfy than persuasion, persuasion [was] often difficult enough to achieve," the acquittals that Langbein notes may in fact have resulted from a juror expectation of certainty. ${ }^{19}$

In either event, jurors had the obligation to determine according to their own satisfaction the truth of the matters brought before them, and there were no legally required obligations other than that they be

17 John Langbein, Torture and the Law of Proof 80 (1976) [hereinafter Langrein, LAw of Proof]. It may be that Langbein is not utterly wedded to this view that the juror need not have been certain to convict. In his earlier work of comparative criminal procedure, he noted that the "jury standard of proof . . . required that [the officers of the state] establish certainty." John H. Langbein, Prosecuting Crime in the Renaissance: England, Germany, France 206 (1974) [hereinafter Lancbein, Prosecuting Crime].

18 The 3 OED, supra note 16 , at 878 , notes a usage in 1584 in Powel's Lloyd's Cambria at 387: "No Englishman should be convicted except by English Judges." This usage, when more fully considered in its use to describe civil cases, illustrates both the strength and weakness of ascribing the idea of conviction to the action of the juror, whose verdict was necessary to, but only part of, the conviction. In considering the application of law in Wales, Powel noted "And if anie sute happened betweene a Welshman and an Englishman, it, was by law ordeined that the Englishman should not be convict, unlesse it were by the judgment of English Justices, and by the verdict of whole English burgesses." The Historie of Cambria, Now Called Wales (London, Rafe Newberie \& Henrie Denham 1584).

19 Langbein, Law of Proof, supra note 17, at 80 (citing Joel Samaha, Law and Order in Historical Perspective; The Case of Elizabethan Essex (1974); Cecil L'estrange Ewen, Witch Hunting and Witch Trials 98-111 (1929), which detail high acquittal figures in, respectively, witchcraft trials and prosecutions in the Essex Assizes). The current author's own study of the assize rolls in the Home Counties agree with the general conclusions that there was a considerably higher rate of acquittal by late medieval juries than one might expect. 
willing to swear to the truth of their conclusions. This obligation of an oath before God likewise suggests that the juror believed in an independent conviction of the guilt of the accused. Such an obligation would be unlikely to be met by persuasion to a lesser degree than certainty.

Thus, once we can find records of more verbose descriptions of juror instructions, it is not surprising to learn that eighteenth-century jurors were told if they were doubtful, they should acquit. ${ }^{20}$ The decision was left in the unfettered hands of the juror and his "good sence." 21

This degree of lenity in the face of doubt was not always appreciated. In 1785, the influential moralist and priest William Paley railed against jurors, who through "over-strained scrupulousness, or weak timidity" would "not condemn any man, whilst there exists the minutest possibility of his innocence." 22 He believed a worthy reform, making for more convictions, would be for jurors to convict when the "preponderation of evidence is so manifest as to persuade every private understanding of the prisoner's guilt; when it furnishes the degree of credibility upon which men decide and act in all other doubts, and which experience hath shown that they may decide and act upon with sufficient safety." 23

Paley's proposed standard, vague in so many ways, would have at least increased the role of doubt as opposed to certainty, a role that he believed would be important in adopting a standard that would lead jurors more readily to convict the guilty. A juror who might vote to

20 For examples of instructions, see Shapiro, Beyond Reasonable Doubt, supra note 7, at $266 \mathrm{n} .77$. Shapiro quotes appropriately from The Trial of Stuann (1752), in which the prosecutor argued that the evidence was "'so strong, so convincing ... that that Presumption that will rise to a Conviction; there will not remain the least Doubt of it." Id. at 21.

21 See the colonial instructions quoted in William E. Niglson, The Americanization of the Common Law: The Impact of Legal. Chance on Massachusetts SociETY, 1760-1830, at 409 (1976). The concept of doubt played a procedural role as well as a role in the substance of the decision. Blackstone, following Coke, noted that the jury could refer matters in which they were in doubt back to the judge for decision, only reaching a verdict if they were convinced they should convict or acquit without committing a hazard to their oaths. 4 WiLliam Blackstone, Commentaries *354; cf. Dowman's Case, 9 Coke Reports 1, 77 Eng. Rep. 743 (K.B. 1585). One manner in which questions of facts and law were divided was the special verdict, which was voted for on its particular issues but according to the general standards. See BAKER, supra note 8 , at $95-99$.

22 William Paley, Moral and Political Philosophy, reprinted in The Works of WiLliam Paley 27, 141 (Philadelphia, J.J. Woodward 1831).

23 Id., reprinted in The Works of William Paley (Philadelphia, J.J. Woodward 1831). 
acquit must have the same degree of credibility or doubt regarding the prisoner's guilt as the degree of credibility or doubt that the juror would use in daily decisions. Clearly, Paley was attracted to his proposed reform with an eye toward its practical consequence, one he believed would hold the crown to a less rigorous proof of its case. This could be accomplished by encouraging the jurors to decide the verdict not by a momentous standard of proof but by comparing their judgment in the case, and their doubts in the case, with their senses of judgment and doubt that they ordinarily think are sufficient. Although Paley's argument was one for change, change was slow in coming, and other observers were less troubled by the status quo.

It was still quite appropriate then that Justice James Wilson, in his law lectures at the College of Philadelphia in 1790, characterized "the discretionary power vested in juries" by the common law to be the unadorned "power to try the truth of facts . . by evidence." 24 Even so, he found evidence as a basis for proving an historical fact to be so complex that no scientific rule could assess it. Thus, he claimed that "the power of deciding on the evidence of facts must be a discretionary power; for it is a power of deciding on a subject unsusceptible to general principles or rules." 25 The required level of proof was whether the evidence would be such as "would govern the judgment" of every person in society, a standard met in part by requiring unanimity in the jury. ${ }^{26}$

This standard of Justice Wilson's is one of the first analyses, if not the first, to use the standard of proof as a mechanism not only of measuring the sufficiency of evidence as one person's view of the sufficient but also by assigning to it a measure that must be satisfied universally. In other words, Wilson makes clear what had been thought true all along: each juror must privately resolve to determine that the evidence is so strong that every person would convict upon it. The standard incorporates, in this way, the burden of persuasion into the

242 James Wilson, Lectures on Law 306 (1804). Wilson's lecture on the jury, in eighty-four pages, is one of the few substantial treatments on the subject in his age. It is one for which he admits, at least on some issues, to having "investigated minutely and carefully, historically and upon principle." $I d$. at 349 . Wilson and his lectures as a whole are described in Steve Sheppard, Casebooks, Commentaries, and Curmudgeons. An Introductory History of Law in the Lecture Hall, 82 Iowa L. REv. 547, 570-71 (1997).

252 WILSON, supra note 24, at 310; see also 2 id. at 356.

26 In order to find that agreement, Wilson stated that each juror must decide the case according to private sentiment, and if all are agreed to convict, the defendant is convicted. But, he concluded, "If a single sentiment is not for conviction; then the verdict of acquittal is the immediate consequence." $2 \mathrm{id}$. at 355 . This was a marked difference from Wilson's view of a civil jury, in which jurors form their sentiments and "reason together" to a common result. 2 id. at 354-55, 357-60. 
burden of proof. The prosecutor must convince each juror, independently, that the evidence would be sufficient for everyone.

Thus stood matters at the dawn of the republic. The jury was invested with its traditional obligation to try the facts of cases. This discretion was held in each individual juror, of whom the law expected care but in whose sentiments the decision resided, with no requirement of justification to anyone but God Almighty. Even so, the seeds of change had been sown in the ideas of certainty and doubt, which contributed to a continuing dissatisfaction by prosecutors and others with the jury's unfettered power. New ideas were arising that would alter the role of the jury; prosecutors and judges attempting to contain the power of juries would apply ideas drawn from a rather unlikely source, philosophers' attempts to understand the nature of knowledge itself, particularly how one might reconcile belief in God with skepticism about nature.

\section{The Seventeenth Through the Nineteenth Centuries: The Standard Arises-Moral. Certainty and Reasonable DoubT}

British philosophy in the seventeenth and eighteenth centuries was a scene of lively debate on the nature of knowledge and awareness. Radical theological and humanist arguments had arisen to consider new theories of knowledge. Debates over skepticism and epistemology were common throughout the literate classes, sparked not only by new thinking from the likes of Francis Bacon, René Descartes, and Isaac Newton but also by debates among Catholics, Anglicans, and Puritans. Some of these questions had been tamed by Thomas Aquinas and Descartes, who, each in his way, had followed the path of Aristotle in segregating problems of absolute knowledge from knowledge borne of the senses and reason. From them came views that mankind might lack the absolute knowledge of the universe, perhaps known only to God, but that as a thinking being, human beings can and do know some things, not the least being their own existences.

\section{A. Moral Certainty}

In the midst of these debates, new ideas about certainty, as well as about the persuasion and sufficiency of evidence, turned often upon ideas of knowledge in general, claims of reason, and levels of cer- 
tainty, or understandings of probability. ${ }^{27}$ Looking back on these debates, the most important division may have followed the Platonic fault line between form and reality, a division useful in answering medieval skeptical concerns by dividing theology from worldly doubt. ${ }^{28}$

There are other forms, of course, of certainty and of doubt that were open to knowledge by human beings. An idea that was logically true was derived from definition by logic or mathematics. Thus the statement that "every effect has a cause" was true because it is a logically necessary result of the definitions of cause and of effect. Physical certainty was demonstrable from the evidences of the senses and was true if there was no sensory evidence to contradict it.

The most important form of certainty, for the purpose of this Article, was "moral certainty," which is the form of certainty that any person is capable of achieving from an understanding of the nature of things, applying reason and thought to the testimony of others, along with personal observation and experience. Moral certainty stood in contrast to Divine knowledge or metaphysical certainty. This division was initially important in a world in which the doubts of rational skepticism could arouse the interest of ecclesiastical censors, who could be assuaged with proofs that the doubts were not of dogma, which remained happily insulated beyond doubt.

The division between moral certainty and other forms of certainty became widely accepted among the literate classes of England in the $1600 \mathrm{~s},{ }^{29}$ having been employed by natural scientists, such as

27 See Shapiro, Probability, supra note 7, passim (discussing the intersection of these ideas in the seventeenth century).

28 There is a rich literature on the epistemological problems that arise in the conflict between certainty and skepticism, as well as among the various forms and objects of knowledge that might be justified. For a general history of early modern skeptic literature, see Richard H. Popkin, The History of Scepticism from Erasmus TO SPINOZA (1979). The move of emphasizing the division of metaphysics (soon to include theology) from physics (and all other practical enquiries) was made by Aristotle, emphasized by Augustine in his Contra Academicus, and enshrined as dogma by Aquinas. The history of the early modern debate on these matters, and their somewhat resolution through the developments of statistics and the concept of probability has been given several recent treatments. See generally Ian Hacking, The Emergence of Probability: A Philosophical Study of Early Ideas About Probability, Induction and Statistical Inference (1975); Mary Poovey, A History of the Modern Fact: Problems of Knowledge in the Sciences of Wealth and Society (1998); Stephen M. Stigler, The History of Statistics: The Measurement of Uncertainty BEFORE 1900 (1986). To locate these debates in early modern England, see the works of Professor Shapiro, supra note 7, and Roy Porter, The Creation of the Modern World: The Untold Story of the British Enlightenment (2000).

29 See Robert Boyle, Some Considerations About the Reconcileableness of Reason and Religion (1675), reprinted in 4 The Works of the Honourable Robert 
Robert Boyle and Robert Hooke, theologians, such as the Cambridge neo-Platonists, and philosophers, such as, if rather indirectly, John Locke. ${ }^{30}$ The use of the idea most significant to the common law, however, was that by Bishop Wilkins.

\section{B. Bishop Wilkins, Moral Certainty, and Reasonable Doubt}

Although he is almost completely unknown today, the influence of John Wilkins upon his age was considerable. The Warden of Wadham College, Oxford, and the guardian there of intellectual independence during the Commonwealth (a task made easier by his marriage to Oliver Cromwell's sister), Wilkins chaired the meeting to found the Royal Society in 1660 and was its first secretary. ${ }^{31}$ Even if Wilkins was not as brilliant a thinker as many of his contemporaries, his influence was vast, and his posthumously released Of the Principles and Duties of Natural Religion went through several editions. ${ }^{32}$ That work not only established moral certainty as the touchstone for thought and skepticism in matters of disputed historical fact, but also tied it to the notion of reasonable doubt.

For Wilkins, the very nature of certainty was the same as knowledge. It was " $[t]$ hat kind of Assent which doth arise from such plain and clear Evidence as doth not admit of any reasonable cause of

Boyle 182 (Thomas Birch ed., 1772); Ralph Cudworth, The True Intellectual System of the Universe: The First Part: Wherein All. the Reason and Philosophy of AtHeism Is CONFuted and ITS Impossibility Demonstrated (1678).

30 See John Locke, An Essay Concerning Human Understanding 538 (Peter $\mathbf{H}$. Nidditch ed., 1975) (1690) ("[T]here are different degrees and ways of Evidence and Certainty."); see also Shapiro, Moral Certainty, supra note 7, at 158 (discussing Locke's understanding of moral certainty as the highest species of probability).

31 See John Aubrey, Aubrey's Brief Lives 319-20 (Oliver Lawson Dick ed., 1957); M. Jamie Ferreira, Schipticism and Reasonable Doubt: The British Naturalist Tradition in Wilkins, Hume, Reid and Newman 10, 12 (1986); P.A. Wright Henderson, The Life and Times of John Wilkins 90 (1910); Marcery Parver \& E.J. Bowen, The BEginNing, of tHe Royal Society (1960). Barbara Shapiro, once again, has the outstanding contribution in the field. See Barbara J. Shapiro, John Wilkins, 1614-1672: AN INTELlegtual Biography (1969).

32 The first edition was published in 1675 , three years after Wilkins's death. JOHN Wilkins, Of the Principles and Duties of Natural Religion: To Which Is Added, A Sermon Preached at His Funerals, by William Lloyd, D.D. (London, A. Maxwell 1675). The work was reprinted in 1683, 1693, 1699, 1710, and 1734, as well as in his collected works in 1707. W. Grimmett, The Mathematical and Philosophical. Works of the Right Reverend John Wilkins, Late Lord Bishop of Chester to Which Is Prefix'd the Author's Life, and an Account of His Works (London, J. Nicholson et al. eds. 1707). 
doubting." ${ }^{33}$ Certainty was distinguished from matters of opinion and probability and divided into three categories: physical, mathematical, and moral. All of these forms of certainty could arise from self-evident understanding, from first principles that cannot be proved from inference, or from deduction. Matters fit for moral certainty were less perfectly provable than physical and mathematical certainty.

I call that Moral Certainty, which hath for its object such Beings as are less simple, and do more depend upon mixed circumstances. Which though they are not capable of the same kind of Evidence [as mathematical and physical matters] so as to necessitate every man's Assent, though his judgment be never so much prejudiced against them; yet they may be so plain that every man whose judgment is free from prejudice will consent unto them. And though there be no natural necessity, that such things must be so, and that they cannot possibly be otherwise, without implying a contradiction, yet may they be so certain as not to admit of any reasonable doubt concerning them. ${ }^{34}$

Wilkins asserted that moral certainty of a conclusion could result from considering three forms of evidence: evidence arising from the nature of things, ${ }^{35}$ evidence from testimony, and the evidence of personal experience. ${ }^{36}$

Wilkins's influential notion of moral certainty therefore incorporated three elements: the domains of consideration (the practical world not provable by faith or mathematics), the form of thought (reasoned and, we may infer, without conscious prejudgment), and the sources of evidence (the nature of things, testimony, and experience). It also dictated a level of confidence in the evidence.

Its measurement depended, however, on a sufficiency of evidence or confidence in the evidence, because a matter of moral certainty had to be so certain that no one without a prejudice would dissent

33 John Wilkins, Of the Principles and Duties of Natural Religion 7-8 (Richard H. Popkin ed., 1969) (1693).

34 Id. at $7-9$.

35 As examples of knowledge derived from the nature of things, Wilkins offered several propositions. One of these seems to the modern mind to be uncontroversial: "that a Mind free from passion and prejudice, is more fit to pass a true judgment, than such a one as is byassed with affections and interests." Id. at 9-10. Others, however, are more contingent on the views of the time, although probably they are only academically controversial today: "That there are such things as Vertue and Vice. That Mankind is naturally designed for a sociable life." Id. at 10.

36 Wilkins offered as examples that he was morally certain from testimony alone to be morally certain that there had been such a person as Queen Elizabeth and such a place as Spain, and from his experience had no reason to doubt that the house he was in should not fall upon him the next second. $I d$. 
from it. At a lesser degree of confidence arising from the same evidence, Wilkins found not moral certainty but only opinion and probability. ${ }^{37}$ Thus, Wilkins believed that when evidence for a point is less than that which would necessitate every unprejudiced person's assent, the point was, as he put it, a matter of reasonable doubt. ${ }^{38}$

This last point suggests one essential requirement for moral certainty: a reasonable person was capable of moral certainty. While his illustration of moral certainty includes a passage that proclaims a true judge to be one not "bypassed with affections and interests," 39 the nature of the bias Bishop Wilkins had in mind is not necessarily clear to the modern reader. Beyond the obvious problem of someone unfairly prejudging an issue on a basis other than according to the nature of a thing, an implied requirement would have been that the person was sufficiently sane to become certain and to avoid prejudice. It might also have excluded Roman Catholics and others whose religious conviction or creeds were perceived by the state to demand prejudgment. ${ }^{40}$

Lastly, and in the context of legal judgment perhaps most tellingly, is the double meaning of Wilkins's understanding of the moral element of moral judgment. While one might, as we have so far, read the moral element as strictly a neutral concept related to practical action, one might also read it as an ethical concept related to judgments of right and wrong. Clearly, Wilkins implied both readings, and his illustrations, that unprejudiced judgment is good, that there are Virtue and Vice, and that humans are sociable creatures, are related to both forms of moral certainty. ${ }^{41}$

\section{Moral Certainty and the Law}

Although moral certainty would confuse later generations, the lawyers of the seventeenth century lived in the light of a general ac-

37 Id. at 10-11. This approach was followed by Locke. Locke, supra note 30, at 657-58. Locke converted Wilkins's notion of universal assent from "moral certainty" to "the highest degree of probability." Locke elaborated Wilkins's view rather directly. See id. at 663-64.

38 See FERreira, supra note 31 , at 15 (noting that other authors of the period "refuse [d] to equate unreasonable doubt with impossible doubt"); WiLkins, supra note 33 , at 7-11 (discussing Wilkins's distinction between reasonable and unreasonable doubt).

39 WiLkins, supra note 33 , at 10.

40 See Theodore Waldman, Origins of the Legal Doctrine of Reasonable Doubt, $20 \mathrm{~J}$. Hist. IDEAS 299, 301 \& n.10 (1959) (comparing Wilkins's discussion to the views of William Chillingworth and John Tillotson).

41 Wilkins, supra note 33 , at 10. 
ceptance of Bishop Wilkins's approach. To them, discussing a juror's confidence in a verdict in such terms involved no more than a refinement of their form of talk. ${ }^{42}$ There is no evidence that requirements of moral certainty would have been meant to alter the way in which jurors reached their beliefs. It was merely an addition by the educated to their description of what the juror would do, and had in fact been doing. Further, it was not necessarily used with great precision or consistency.

Moral certainty and its correlative forms of doubt were already accepted forms of discourse in the religious treason trials of the Restoration. In Lord Stafford's trial of 1680, prosecutors argued to the English Lords as a jury that, while they had already produced "presumptive evidence which will induce a moral persuasion," the prosecutors would further produce "such positive Evidence as will make a judicial certainty; and will abundantly suffice to convince your Lordships and convict this Lord." 43

This interesting juxtaposition equated "moral persuasion" with "judicial certainty," suggesting that either element might constitute moral certainty. Clearly they reflect the requirements for which Wilkins had promoted moral certainty-an amount of testimony, in the light of personal knowledge and experience, that could persuade a person who must judge that the basis for the judgment was beyond doubt. Even the last element, that the judgment was beyond doubt, was in the prosecutors' minds. They summed up their case with the assertion that the evidence was "so strong that ... it admits of no doubt." 44

Moral certainty entered the common law in the young United States with some ease. In 1795, the Connecticut Superior Court reversed a justice of the peace's conviction for disturbing the peace without a finding of guilt by moral certainty. ${ }^{45}$ In one of the treason trials related to the Burr conspiracy, the U.S. Attorney General argued that the ease that Aaron Burr predicted he would have in raising troops gave rise to a moral certainty that he had already raised some. ${ }^{46}$ In other words, proof of an effect gave rise to a moral certainty of a necessary cause.

42 See Shapiro, Moral Certainty, supra note 7, at 162-68 (discussing the seventeenth-century use of the "satisfied conscience" as a precursor to "reasonable doubt," in which the juror's moral certainty is associated with their oath).

43 The Tryal of William Viscount Stafford for High Treason 40-41 (London, John Bill, Thomas Newcomb, \& Henry Hills 1680).

44 Id. at 186.

45 Knowles v. State, 2 Root 282 (Conn. Super. Ct. 1795).

46 Ex parte Bollman, 8 U.S. (4 Cranch) 75, 115-16 (1807). 
In a classic example of the expectation of the juror to act on the basis of moral certainty, ${ }^{47}$ in 1838 Francis Lieber depicted the juror's task as resting solely on the demand that the juror apply a legal standard of moral certainty based on a social obligation both to find the truth from the evidence in the case and to apply the law governing the crime alleged. Lieber was careful to distinguish away the idea that the juror must be "morally convinced" of innocence. The jury had no requirement of ascertaining innocence. On the other hand, impliedly, the jurors had a requirement to find guilt, if they could find it by a moral certainty.

The juror, as he is always instructed to do, must judge by the evidence which is brought before him, and nowise by the capricious impression which he may have received elsewhere. Respecting this point, he must remember that the words of the verdict "not guilty" are not of absolute import, but have a legal meaning; that is, the jury, in delivering the verdict, does not mean to say, "We absolutely declare the prisoner at the bar not guilty," nor even that they are morally convinced of his innocence. All that a verdict of not guilty can mean is this:

[a]ccording to the distinct rules of law and the evidence as now laid before us in the course of the trial, the prisoner cannot in the sense of the law, according to such application of it as society demands, be called guilty; or, in other words, according to those rules which society wills us strictly to obey in judging of the prisoner, he has not been proved guilty. 48

There is no way, at this remove, to know how well the idea of "moral certainty" translated across the often wide division in literacy and class between the lawyers and their lay juror counterparts. One might conjecture that the increasingly diverse venire pool led to an increased difference between the understanding of lawyer and lay juror on a host of fronts. Only one of these differences was the loss of a

47 This example is, of course, written well into the nineteenth century, but it may well be significant to note that this late depiction of the role of the juror makes no mention of reasonableness or reasonable doubt. Although there are earlier examples, Shapiro notes a good early example of the use of moral certainty in the law in Matthew Hale, The Primitive Origination of Mankind 129 (1677), quoted in ShaPIRO, Probability, supra note 7, at 97-98. (discussing that historical facts, which cannot be known by the senses must be discovered by "moral evidence" and not "demonstrative or infallible" knowledge).

482 Francis Lieber, Manual. of Political Ethics 407 (Theodore D. Woolsey ed., 1875). Lieber was then a professor of law in the University of South Carolina; he would later move to Columbia Law School. His surprisingly influential career is described in Frank Burt Freidel, Francis Lieber: Nineteenth Century Liberal (1947); and Lewis R. Haley, Francis lieber: His Life and Political Philosophy (1899). 
common understanding of epistemological niceties, thus exposing jurors to increasingly greater confusion over the notion of "moral certainty."

Regardless of such concerns, moral certainty was the mainstay of juror's obligations for much of the century. ${ }^{49}$ Notoriously, it persisted in some jurisdictions, most importantly California, into the $1990 \mathrm{~s}^{50}$

In the end, the notion of moral certainty is quite simple, although with its rationale having evaporated, the term has simply lapsed into disuse and been replaced by other tokens. Modern Western culture is notoriously skeptical about many of its older certitudes. The once-raging debates about the nature of God have subsided into a combination of tolerance, agnosticism, and atheism. The need to hive off questions of traditional faith from questions more apparent to us in our everyday lives is less clear, and "moral certainty" became little more than a synonym for "certainty" in the twentieth century. In other words, for a writer in 1800 to claim, "I am morally certain," roughly equates to my saying two centuries later, "I am as certain as I can be, based on what I have seen and heard."

\section{Reasonableness of the Juror's Doubts}

Initially, "reasonable" as a qualification to thought and to jurors' doubts may have been as benign a change as the introduction of "moral certainty," with which it shares many common origins. In short order, though, a requirement to find certainty beyond a reasonable doubt became a significant restriction on the independent discretion of the individual juror, a change prompted rather deliberately by prosecutors.

The Age of Reason was a time of tremendous social, technological, and philosophical change, and in the seventeenth century, the ideal of reason became the measure of sound, practical judgment. Of writers in this vein, the most influential in England was John Locke, who wrote of conscience and belief as matters of reason, which would

49 See, e.g., Mose v. State, 36 Ala. 211, 231 (1860) (noting that "[u]nless the jury are morally certain of the defendant's guilt, it cannot be said that they have no reasonable doubt of his guilt"); State v. Miller, 32 A. 137, 141 (Del. Sup. Ct. 1892) (noting that " $[\mathrm{m}]$ atters of fact are required to be proved merely to a moral certainty"); Parrish v. State 15 N.W. 357, 360 (Neb. 1883) (upholding jury instruction that "[m] orally satisfactory and convincing" proof satisfies the law); Smith v. State, 10 Tex. App. 420, 421 (1881) (noting that a conviction mandates moral certainty in the proof).

50 See infra note 223. 
support categories of knowledge and of certainty. ${ }^{51}$ Locke's view that reason can form the basis for probability and certainty provoked a bitter dispute between two great Scots, David Hume and Thomas Reid. Hume argued for an unrelieved skepticism in determining both the role of reason in judgment and the nature of human knowledge. ${ }^{52}$ Reid, the leader of the school of common-sense thought, argued that far from being the object of skepticism, "Judging is an operation of the mind so familiar to every man who hath understanding, and its name is so common and so well understood, that it needs no definition." 5.3 Very simply, lawyers of the late eighteenth century, attracted to the certitude (or appearance of certitude) in such a pragmatic vision, were drawn to a position much nearer to Reid's. ${ }^{54}$

51 Locke famously asserted three categories of our sources of knowledge-intuition, demonstration, and sensation-which formed the basis for probabilities of certainty. Locke explains a universal intuition as a propositions that "border so near upon Certainty, that we make no doubt at all about them." Locke, supra note 30 , at 655. Personal experience that is in agreement with the experience of others is the basis of "confidence." Id.

The concurrent testimony of reliable witnesses who agree on a matter makes assent "unavoidable." Id. at 659. All of these lead to a progression of assent, ranging down through "belief, conjecture, guess, doubt, wavering, distrust, disbelief, etc." Id. at 661-64. Assent was a component of judgment. Id. at 686-87.

52 See David Hume, Enquiries Concerning: Human Understanding and Concerning the Principles of Morals (L.A. Selby-Bigge ed., Clarendón Press 1975) (1777).

53 Thomas Reid, Thomas Reid's Inquiky and Essays 251 (Keith Lehrer \& Ronald E. Beanblossom eds., 1975).

54 See Thomas Reid, Essays on the Intellectual and Active Powers of Man (1793). In this context, Reid's greatest contribution may have been in his discussion of contingent truths, particularly his arguments for reliance on human faculties of sense. Not all lawyers, of course, followed Reid's path, as will be seen below in the consideration of Chief Justice Shaw's views incorporating more complex ideas. Moreover, the Scottish bar, of which Hume was a leading member, moved in a different direction, one that included the Scots' verdict of "not proven." There were, to be certain, a variety of views of the gauge of certainty that could be afforded to evidence. The most compelling in today's intellectual climate probably would remain that of Jeremy Bentham, who, considering the complex morass of probabilities and presumptions with which the seventeenth- and eighteenth-century law judged proof, rejected all intermittent limits seeking to define the scale of probativity of evidence or sufficient persuasion for a judge. Rather, he argued for allowing evidence to the highest level or persuasion, measured against an ideal of an "infinite scale." 1 JeREMY BENtham, Rationale of Judicial Evidence 100-06 (London, Hunt \& Clarke 1827). All of these approaches were meant to reform a process grown hidebound by a slavish reliance on pleading. William Twining presents a superb discussion of Bentham's efforts at evidentiary reform through rationalism. See William Twining, Theories of Evidence: BenTHam \& Wigmore (1985). 
"Reasoriableness," of course, antedates by centuries the war between Hume and Reid. The word evolved early in the English language, representing at least three fundamentally distinct, but related, notions: the endowment of reason, the capacity for judgment, and the ability of rational discourse. ${ }^{55}$ The interplay among these different meanings, and varying emphases among them, is an essential part of both the word's history and its increasingly confusing role in law.

This interplay also aided the use of reason in increasing the monopoly of lawyers over legal decisions by emphasizing the artificial nature of the reason employed in legal analysis. In one of its most celebrated instances, Sir Edward Coke employed "common right and reason" as the sine qua non for assessing the powers of Parliament. ${ }^{56}$ And yet, this common reason was part and parcel of the "artificial reason of the law," which could not easily be understood, much less employed by anyone who was not schooled in the precedents and methods of legal argument. ${ }^{57}$ Granted, this use of reason-effectively as a synonym for the law itself-was still limited to determine the reason that was in the law, and not reasonableness in the judgment of jurors. ${ }^{58}$ Reason, that is, legal reason as opposed to natural reasonwas the tool of a hegemonic move by the officials of law to establish sole authority over certain types of decision in the law.

Beyond this dispute in the nature of law, however, concern persisted over the role of reason in judgment, the natural reason contrasted to artificial legal reason. ${ }^{59}$ In general, the prime requirement

55 The OED cites Chaucer's fourteenth-century usages, among others, for all three points. 8 OED, supra note 16 , at 291.

56 Dr. Bonham's Case, 8 Reports 212 (1608), reprinted in 2 The Selected WRITINGS OF Sir EDWARd Coke, supra note 11.

57 See Prohibitions del Roy, 12 Coke's Reports 63 (1609), reprinted in 1 THE SELEGTEd Writings of Sir EdWard Coke, supra note 11.

58 The most important medieval use of reasonableness in the common law was to describe the portion of an estate taken by a widow and children, the reasonable part, described in 9 Hen. 3 c. 18. See 2 William Blackstone, Commentaries *492; Edward Coke, Second Institute of the LaWes of England 33, in 2 The Selected Writings OF SIR EDWARD CokE, supra note 11. This use of reasonable, a translation of rationalibus incorporated both the ideas of fairness and meetness, but it was a very technical application and rather far from the lay judgment required of the juror.

59 Coke contrasted James I's abilities as someone with natural reason with someone with the reason necessary to adjudge law cases. On the one hand, "true it was, that God had endowed his Majesty with excellent science and great endowments of nature," but on the other, "his Majesty was not learned in the Lawes of Realm of England, and causes which concern the life, or inheritance, or goods, or fortunes of his Subjects; they are not to be decided by naturall Reason but by the artificiall Reason and judgement of the law." 2 The Selected Writings of Sir Edward Coke, supra note 11 . 
of reason in the process of judgment was, in the seventeenth century, that a judgment should be made by a reasonable arbiter. It was not based on rationality, but on a certitude that a reasonable person could achieve. ${ }^{60}$ Accordingly, reasonable doubt was, by definition, merely a doubt held by a reasonable person. ${ }^{61}$ The idea of the reasonable person was, itself, just then taking hold of the legal imagination. ${ }^{62}$

Colonial courts found reasonableness in the judicial lexicon decades before it was to be employed to qualify doubt before the jury. ${ }^{63}$ Reasonableness was an important qualification for the satisfaction of legal obligations. ${ }^{64}$ It was also an important qualification for both legal instruments and agreements ${ }^{65}$ and judicial acts, especially in the construction of liability ${ }^{66}$ and of private instruments such as wills ${ }^{67}$

60 Hill, supra note 1, at 245-47.

61 Walter Charleton, The Immortality of the Human Soul Demonstrated by THE LiGHT OF NATURE 186-87 (London, William Wilson 1659) (discussing establishment of the "truth" of the soul's immortality "in the mind of a reasonable man"); Shapiro, Probability, supra note 7, at 33 (citing Chiarles Wol.seley, The Unreasonablenes of ATHEISM MADE MANifest 147 (3d ed. 1675) and stating if "testimony was sufficient to 'satisfie a rational man,' moral certititude was possible"); WiLKINS, supra note 33 , at 5 (noting that assent derived "from such plain and clear evidence as doth not admit of any reasonable cause of douting, is called knowledge of certainty").

62 See Baker, supra note 8, at 342-48 (citing, inter alia, Francis Buller, Introduction of the law Relative to Trials at Nisi Prius (1768); and William Jones, Essay on the Law of Bailments 6 (Dublin, Printed for Elizabeth Watts 1781)). Of course, the idea of reasonableness as a distinctive element of a belief held by thoughtful people had broader appeal than the law, as we have seen from Bishop Wilkins's approach. Reasonableness as a basis for Christian belief was central not just to Wilkins, though. See John Locke, The Reasonableness of Christianity (Ian T. Ramsey ed., Stanford Univ. Press 1958) (1695).

63 On the development of the jury in colonial courts, see generally Bradley CHApin, Criminal Justice in Colonial America, 1606-1660, at 40-50 (1983); and Edogar J. McManus, Law and Liberty in Early New England: Criminal Justice and Due Process, 1620-1692, at 98-111 (1993).

64 See, e.g., Dulany v. Jenings, I H. \& McH. 92, 92 (Md. Ch. Ct. 1738) (noticing Proprietor Lord Baltimore's 1684 edict that claims to land patents are not barred by a strict time but by a reasonable time); Davis v. Richmond, 14 Mass. 473, 474 (1768) (holding that the sheriff was ordered to deliver debtor's lands and property at reasonable price).

65 See Gresham v. Gassaway, 1 H. \& McH. 34, 34 (Md. Prov. Ct. 1718) (holding that sheriff's bond from undersheriff was conditioned on "reasonable request" for execution of instruments).

66 See, e.g., Brown v. Cornwell, 1 Root 60, 60 (Conn. Super. Ct. 1773) (holding that the owner of ship's cargo required to contribute for loss to owner of stock animals lost at sea in storm because, "when the stock upon deck is thrown overboard for the express purpose of saving from destruction the cargo in the hole, it is but reasonable that the cargo saved should bear a proportion of the loss, which was the price of its ransom"); Graves v. Boyd, 1 Va. Colonial Dec. R45, R45 (Gen. Ct. 1730) (stating 
and leases. ${ }^{68}$ William Blackstone enshrined Coke's articulation of reasonableness binding the extent of custom. ${ }^{69}$ Of course, reasonableness could rarely overwhelm the clear dictates of a common-law rule, which were each expected to themselves be reasonable. ${ }^{70}$

After independence, reasonableness remained a test of private liability. ${ }^{71}$ It also quickly became a tool in the interpretation of statutory instruments, ${ }^{72}$ treaties, ${ }^{73}$ judicial powers, ${ }^{74}$ and constitutional duties. ${ }^{75}$ Reasonable doubt, indeed, has continued to play a role in

that the chancellor will consider contingent reasonableness of a bargain before enforcing contract).

67 See, e.g., Tazewell v. Harmanson, 2 Va. Colonial Dec. B147, B148 (Gen. Ct. 1741) (more reasonable construction of will provision is preferable).

68 See, e.g., Norris's Lessee v. Pottee, 4 H. \& McH. 508 (Md. Prov. Ct. 1768) (holding that in a lease construction, " $[t]$ he law will make such a reasonable intendment upon the whole, as will restrain the general words from affecting Preston by his warranty, which was never intended or thought of by the parties"); Booth v. Dudley, 1 Va. Colonial Dec. R10, R11 (Gen. Ct. 1729) (holding that preferred construction of lease was one that was reasonable and grammatical).

69 I BlackstONE, supra note 21, at *77-78 (discussing reason's limit upon cüstom).

70 See, e.g., Brock v. Lyne, 2 Va. Colonial Dec. B111 (Gen. Ct. 1740) (holding that effect of rules of succession in tail do not depend on reasonableness of the results); see also the later case of Picket v. Dowdall, $2 \mathrm{Va} .106$ (1795). Blackstone, in the introductory sections to his great Commentaries, noted that the law operated as authority so to bar independent assessment of the law's reasonableness. 1 BLACKSTONE, supra note 21 , at *44. Furthermore, Blackstone rejected Coke's edict that statutes contrary to reason are unenforceable. $1 \mathrm{id}$. at $* 91$.

7172 See Freary v. Cooke, 14 Mass. 488 (1779) (holding that the custom awarding a one-season monopoly of a seine fishing site to the person who clears it is unreasonable and void).

72 See Gustin v. Brattle, 1 Kirby 299 (Conn. Super. Ct. 1787) (holding that a reasonable construction is preferable to a strict construction of statute creating savings for disabilities to suit for defendants out of the country for commercial reasons); Ingles v. Bringhurst, 1 U.S. (1 Dall.) 367, 370-71 (Ct. C.P. Phila. 1788) (holding that statute providing permanent lien for common wall is a "a reasonable and useful regulation, calculated to prevent animosities and disputes").

73 See Ware v. Hylton, 3 U.S. (3 Dall.) 199, 249 (1796) (Patterson, J.) (noting reasonableness is one consideration in determination the intention of parties).

74 See Gilbert v. Marcy, 1 Kirby 401 (Conn. Super. Ct. 1788) (illustrating that without a statute, court may enforce reasonable requirement to keep criminal prosecution in district of the crime).

75 See, e.g., Commonwealth v. Posey, 8 Va. (4 Call) 109, 126 (1787). In Posey, the court questioned,

And is it not reasonable that the same view of the official oath should be taken by a legislator, acting under the constitution, which is his guide, as is taken by a judge, acting under the law, which is his? There is in fact and in common understanding, a necessity of regarding a course of practice, as above characterized, in the light of a legal rule of interpreting a law: and 
constructing the standards of constitutional sufficiency. Despite its failure to achieve prominence as a test under the federal constitution, ${ }^{76}$ it has remained a standard of state review of fit between a statute and a constitution. ${ }^{77}$

there is a like necessity of considering it a constitutional rule of interpreting a constitution. Id.

76 See Ogden $v$. Saunders, 25 U.S. (12 Wheat.) 213, 270 (1827) (Washington, J.), in which Justice Bushrod Washington used reasonable doubt in two different senses in as many breaths:

It is but a decent respect due to the wisdom, the integrity, and the patriotism of the legislative body, by which any law is passed, to presume in favour of its validity, until its violation of the constitution is proved beyond all reasonable doubt. This has always been the language of this Court, when that subject has called for its decision; and I know that it expresses the honest sentiments of each and every member of this bench. I am perfectly satisfied that it is entertained by those of them from whom it is the misfortune of the majority of the Court to differ on the present occasion, and that they feel no reasonable doubt of the correctness of the conclusion to which their best judgment has conducted them.

Id. This test for constitutional validity, in lieu of a finding of "repugnance" or other failures of fit, did not catch on, perhaps because Chief Justice Marshall dissented in Ogden, clearly preferring a less laden test:

It is well known that the Court has been divided in opinion on this case.

Three Judges, Mr. Justice Duvall, Mr. Justice Story, and myself, do not concur in the judgment which has been pronounced. We have taken a different view .....

The single question for consideration, is, whether the act of the State of New-York is consistent with or repugnant to the constitution of the United States?

Id. at 332. (Marshall, C.J., dissenting). Despite its use in state courts, see infra note 77, this standard appears only once later to have been argued to the Court, in Northwestern University v. People ex rel. Miller, 99 U.S. 309 (1878), although no discussion of the putative standard was reached in the opinion by Justice Miller.

77 See, e.g., Rich v. Flanders, 39 N.H. 304 (1859) (deciding the constitutionality of a retrospective law using a beyond-all-reasonable-doubt standard); McMillen v. Boyles, 6 Iowa (Clarke) 304 (1858) (employing reasonable-doubt language in analysis of a state statute). Many state courts applied this test to uphold statutes. Some courts applied it with more moderate deference, including one of the most influential state cases, In re Wellington, 33 Mass. (16 Pick.) 87 (1834). In considering the question whether a state enclosure act was constitutional, Chief Justice Shaw thought it "not improper to repeat what has been so often suggested by courts of justice, that . . courts ... never declare a statute void, unless the nullity and invalidity of the act are placed, in their judgment, beyond reasonable doubt." $J d$. at 95 . Such a standard of care was balanced, though, by constitutional policies expressed in one tremendous sentence:

Still however it cannot be doubted, and I believe it is nowhere denied, that in a limited government like ours, acting under a written constitution with 
So it is no surprise that in the eighteenth century, the idea of "reasonable" took on more specific meanings in the context of a juror's duty. The first major importation of the new view of reason to the law of criminal evidence was in Baron Geoffrey Gilbert's mideighteenth-century Evidence, which was essentially the first treatise in

numerous and detailed provisions, a constitution which is in itself perpetual and irrepealable except by the people themselves, and which imposes many. restraints upon the power of the legislature by express provisions and many others by necessary implication, and where the same constitution has provided for the establishment of a judiciary as a coordinate department of the government, with power in all cases to expound the laws, to declare what has and what has not the force of law, and to apply them to the investigation and adjustment of the rights, duties, and obligations of citizens, in the actual administration of justice, it is clearly within the power, and sometimes the imperative duty of courts, to declare that a particular enactment is not warranted by the power vested in the legislature, and therefore to the extent, to which it thus exceeds the power of the legislature, it is without efficacy, inoperative, and void. The upshot of this balance was to support the requirements of standing to challenge a statute and a rebuttable presumption in favor of constitutionality.

Id. at 95-96. The test of a statute's constitutionality did not always follow this formula. For example, the Alabama Supreme Court, shortly before the American Civil War, rejected such a stringent deference to its state legislature:

On the measure of proof necessary to set aside a statute as unconstitutional, the language of the adjudged cases varies. In some cases it is said, that the expressed will of the legislature ought not to be disregarded, unless the unconstitutionality be clearly demonstrated. In another case it is said, that we should not hold that the legislature had exceeded its power, except in cases admitting of no reasonable doubt. ... With due respect, we think this language entirely too strong. It indulges, in favor of legislative infallibility, the same strength of presumption as that which obtains in favor of innocence when the life or liberty of the citizen is jeoparded in the courts of criminal jurisdiction. Constitutional provisions are intended as a protection to life, liberty and property, against encroachment, intentional or otherwise, at the hands of the government. Had not the framers of our system of government supposed it possible that legislative bodies might fall into error, they would not, in their sovereign capacity, have adopted a written constitution, superior alike over themselves and the legislature. We cannot believe that construction a sound one, which indulges every reasonable presumption against the citizen, when the legislature deals with his rights, and gives him the benefit of every reasonable doubt, when his life and liberty are in jeopardy before the courts of the country.

Moore v. Wright \& Rice, 34 Ala. 31 1, 321 (1859) (Stone, J.) (citations omitted). Compounding the role of reasonable doubt in statutory interpretation, it was also a gauge of the ambiguity of a statute. See, e.g., Thomas v. Dakin, 22 Wend. 9, 80 (N.Y. Sup. Ct. 1839) (Nelson, C.J.) (holding that statutory meaning subject to reasonable doubt must not be overturned unless the legislature clearly oversteps its bounds). 
the field. ${ }^{78}$ An often garbled twist on the Lockean approach, Gilbert required that facts be proved by best evidence, that the law recognize that each person has a separate intuition, and that a juror confronted with moral evidence must decide if the juror's judgment "equally acquiesces therein as on a knowledge by Demonstration, for it cannot have any more Reason to be doubted than if we ourselves had heard and seen it." ${ }^{9}$ The reader is left to personal initiative to understand it.

The earliest use of the idea that the jury is expected to find guilt if it considers the evidence beyond a reasonable doubt appears to have been a few years after the appearance of Gilbert's book. The first record of it now known was in the trials of British soldiers who killed five colonists at the Boston Massacre. ${ }^{80}$ Two trials arose from the shootings, one of the captain, in Rex $v$. Preston, ${ }^{81}$ and one of the eight soldiers, Rex $v$. Wemms. ${ }^{\text {.2 }}$

John Adams and Josiah Quincy appeared for the defense. At least in Wemms, of which we have a fuller record, ${ }^{83}$ Adams argued that

78 Geoffrey Gilber', The Law of Evidence (1756) [hereinafter Gilbert, EviDENCE]. The first edition, in 1754, had been printed in Dublin, a corrected and enlarged 1756 edition being the first in London. There would be many later editions of the treatise. Gilbert had already acquired a reputation as a scholar in the field thanks to his continuation of Nelson's case collections in evidence. See Geoffrey Gilbert, The Law of Evidence. (3d ed. 1769).

79 GiLbert, Evidence, supra note 78, at 4. A later edition edited by Capel Lofft has an added footnote, ascribing this view to David Hartley, John Locke, Richard Price, John Watts, and John Wilkins. Geoffrey Gilbert, The LaW of Evidence in (Capel Lofft ed., 1795). Gilbert was a devoted fan of Locke's theories, even if they apparently confused him, as witnessed by Gilbert's unusual employment of the idea of intuition. Gilbert published a monograph on Locke's theory. See Geoffrey Gilbert, An Abstract of Mr. Locke's Essay on Human Understanding (Capel Lofft, ed. Dublin 1795) (1752).

80 The first discussion of the Boston Massacre cases in this light was in Morano, supra note 7 , at 508 . Until 1975 , the consensus was that the instruction began life much later, in the Irish treason trials of the 1790s. See 5 John Henry Wigmore, A Treatise on the Anglo-American System of Evidence in Trials at Common law $\$ 2497$, at 464 (2d ed. 1923) [hereinafter WIGMORE, EvidencE]; John Wilder May, Some Rules of Evidence: Reasonable Doubt in Civil and Criminal Cases, 10 AM. L. Rev. 642, 657-58 (1876) (discussing use of a reasonable-doubt standard in Irish treason cases). The current author has yet to find such a clear usage of the standard of proof beyond a reasonable doubt prior to Rex v. Preston and Rex $v$. Wemms.

81 See 3 Legal Papers of Jorin Adams 46-98 (L. Kinvin Wroth \& Hiller B. Zobel eds., 1965) (providing minutes, notes, and summaries of these cases) [hereinafter Legal Papers of Adams].

82 Id. at $98-314$.

83 Adams likely made a similar closing in Preston; he is thought to have argued from the same authorities in each trial. Id. at 242 n. 180 . 
Chief Justice Hale had rightly described the traditional view of the juror's duty in doubt: "Where you are doubtful never act; that is, if you doubt the prisoner's guilt, never declare him guilty; this is always the rule, especially in cases of life." 84 Adams argued that the jury should apply that rule and not convict if the juror has doubts.

The prosecutor, however, argued that John Adams's view was not enough. Robert Treat Paine, arguing as crown prosecutor, told the jurors that the mercy of the law was in its reason, agreeing with Adams insofar as that the law would not admit as certain an argument of which there was a doubt. But he made this qualification:

[i]f therefore in the examination of this Cause the Evidence is not sufficient to Convince you beyond reasonable Doubt of the Guilt of all or any of the Prisoners by the Benignity and Reason of the Law you will acquit them, but if the Evidence be sufficient to convince you of their Guilt beyond reasonable Doubt the Justice of the Law will require you to declare them Guilty and the Benignity of the Law will be satisfyed in the fairness and impartiality of their Tryal. ${ }^{85}$

The jury acquitted six and found two guilty of manslaughter. ${ }^{86}$

The two scholars who have considered the significance of the instructions in the case, Anthony Morano and Barbara Shapiro, disagree as to their intended effect, particularly as to whether the requirement of reasonableness was meant to limit the degree of doubt that should require acquittal. Professor Shapiro, a historian, considered modification by reasonableness to be a natural application of the perceived advances of thinking and no real departure from the earlier standard of conscience or doubt. ${ }^{87}$ Professor Morano, a lawyer, maintained that the reasonable-doubt rule "had the effect of reducing the prosecutor's burden of proof in criminal trials." 88 As a reason for prosecutors to seek such a rule, Morano noted that new rules of evidence had then not only recently allowed the defendant to produce exculpatory evidence but restricted the material the prosecution could present, making more difficult the proof of a case beyond all doubt. ${ }^{89}$ To this one might add the recently won freedom of jurors from the danger of fine or imprisonment for finding a verdict against the state, ${ }^{90}$ as well

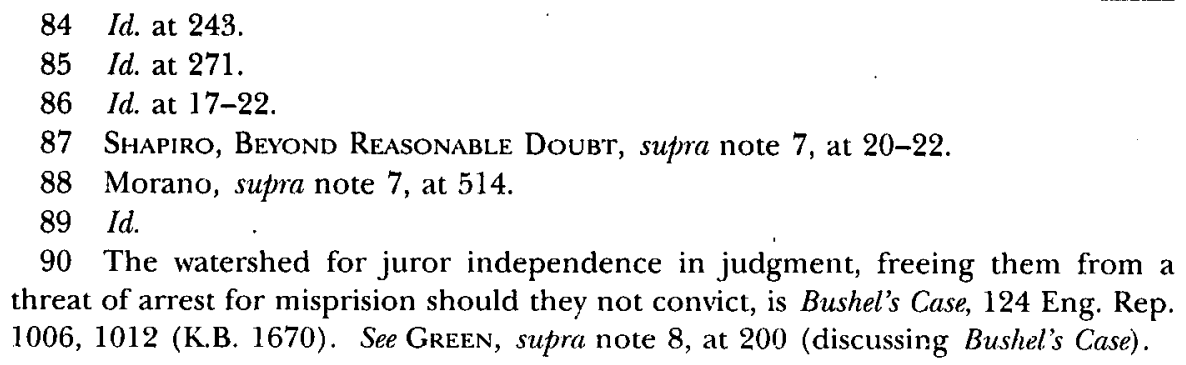
threat of arrest for misprision should they not convict, is Bushel's Case, 124 Eng. Rep. 1006, 1012 (K.B. 1670). See GreEN, supra note 8, at 200 (discussing Bushel's Case). 
as the defense's right to counsel, just recently won in the colonies and still unknown in England, ${ }^{91}$ and a generally growing mistrust by the landed classes of the increasingly petit bourgeois juries. ${ }^{92}$ Given that we have yet to discover a record of Robert Treat Paine's preparation for the trial, there is room for speculation as to the prosecutor's actual intentions.

Regardless, there is no other reason why the hypotheses of Professors Shapiro and Morano might not both be correct in part. The instruction both accords with the new language of the times and contrasts with the language of the defense, to the benefit of the state in jury deliberations. ${ }^{93}$ Thus, we may fairly conclude that the prosecutor's use of the argument both was designed subtly to help the prosecution's case but accorded with contemporary views about the nature of judgment. ${ }^{94}$

91 See 2 Zephaniah Swift, A System of The Laws of The State of Connecticut 398-99 (1795-1796) ("We have never admitted that cruel and illiberal principle of the common Law of England that when a man is on trial for his life, he shall be refused counsel ...."). Justice Sutherland, reviewing the English refusal of counsel to defendants, summarized the colonial American view of the English rule:

The rule was rejected by the colonies. Before the adoption of the federal Constitution, the Constitution of Maryland had declared "That, in all criminal prosecutions, every man hath a right ... to be allowed counsel; ..." (Art. XIX, Constitution of 1776). The Constitution of Massachusetts, adopted in 1780 (Part the First, Art. XII), the Constitution of New Hampshire, adopted in 1784 (Part I, Art. XV), the Constitution of New York of 1777 (Art. XXXIV), and the Constitution of Pennsylvania of 1776 (Art. IX), had also declared to the same effect. And in the case of Pennsylvania, as early as 1701, the Penn Charter (Art. V) declared that "all Criminals shall have the same Privileges of Witnesses and Council as their Prosecutors"; and there was also a provision in the Pennsylvania statute of May 31, 1718 (Dallas, Laws of 1700-1781, Vol. 1, p. 134), that in capital cases learned counsel should be assigned to the prisoners.

Powell v. Alabama, 287 U.S. 45, 61 (1932).

92 The jury of the eighteenth century, despite its land-owning qualifications, was forbidden to hear cases of poaching or smuggling, trials for crimes that juries of middling commoners would annul. See Douglas Hay, Property, Authority, and the Criminal latw, in Albion's Fatal Tree: Crime and Society in Eighteenth-Century England 39 (Douglas Hay et al. eds., 1975). The division in interest between jurors and the upper and professional classes would increase throughout the nineteenth century with the expansion of American suffrage and, thus, its venire lists.

93 Judge May believed that the reasonable-doubt instruction favored the defense. He appears, however, to have been comparing such an instruction to one that did not concern itself much with any form of doubt. May, supra note 80 , at 656 .

'94 Lawrence Solan likewise concludes that Morano's and Shapiro's positions do not necessarily conflict, but Solan emphasizes the difference in scope of their studies, Morano considering the instruction in the light of American cases, and Shapiro in the light of English cases. Solan, supra note 5, at 111 n.24. 
In the earliest use on the American bench-or at least in the earliest published opinion I have found reflecting use on the American bench-of reasonableness as a qualification of certainty and doubt related to a verdict, President Shippen, speaking for the Pennsylvania Court of Common Pleas in 1790 in Cowperthwaite $v$. Jones, ${ }^{95}$ distinguished the confidence a judge must have in a jury's verdict by qualifying acceptable judicial reasons for action with reasonableness:

New trials are frequently necessary, for the purpose of obtaining complete justice, but the important right of trial by jury requires they should never be granted without solid and substantial reasons; otherwise the province of jurymen might be often transferred to the judges, and they instead of the jury, would become the real triers of the facts. A reasonable doubt, barely, that justice has not been done, especially in cases where the value or importance of the cause is not great, appears to me to be too slender a ground for them. But, whenever it appears with a reasonable certainty, that actual and manifest injustice is done, or that the jury have proceeded upon an evident mistake, either in point of law, or fact, or contrary to strong evidence, or have grossly misbehaved themselves, or given extravagant damages, the Court will always give an opportunity, by a new trial, of rectifying the mistakes of the former jury, and of doing complete justice to the parties. ${ }^{96}$

Shippen thus rejected a reasonable doubt in a verdict's justice as sufficient to overturn the verdict, looking instead to the converse, that it must be upheld if there is reasonable certainty that justice was done. Shippen's analysis is important to this discussion, however, in that every element of his analysis-doubt, certainty, and reasons themselves-were qualified by reasonableness. ${ }^{97}$ The reasons by which the judge might act, a set including both doubts about justice and certainty about injustice, must here be "solid and substantial." Both "cer-

952 U.S. (2 Dall.) 55 (Pa. Comm. Pleas 1790). As Philip Hamburger has quite rightly reminded me, the difficulties posed by colonial and early federal reports makes dubious any assertion of a first use of any concept on the early bench.

96 Id. at $55-56$.

97 Shippen was fond of using reasonableness as a test for law. See, e.g., Phile v. The Anna, 1 U.S. (1 Dall.) 218 (Pa. Comm. Pleas 1787) ("[W]e should so interpret the letter of the law, as to render its operation reasonable and just, the source of punishment to the guilty, but of certain acquital to the innocent."); Taylor v. Knox, 1 U.S. (1 Dall.) 170 (Pa. Comm. Pleas 1785) (holding that reasonable rule of habitation for citizenship would require twelve months). He saw no reason for the jury not to assess the reasonableness of others' conduct. See, e.g., Robertson v. Vogle, 1 U.S. (1 Dall.) 271 (Pa. Comm. Pleas 1788) (holding that jury should determine reasonableness of notice to creditor of debtor's intent to dishonor); of. Pons' Ex'rs v. Kelly, 3 N.C. (2 Hayw.) 45 (Super. L. \& Eq. 1798) (holding that jury determines reasonableness of notice). 
tainty" and "doubt, barely," must be "reasonable," although this element in common between doubt and certainty was insufficient to give them common importance. Reasonable concerns to a bare doubt were still not enough for a judge to interfere with a jury's verdict. Even though in this usage, whatever qualification was added to "certainty" or "doubt" by their being reasonable is difficult to assess, Judge Shippen's limit of even a bare doubt to the reasonable would suggest that he believed in a limit to the concept of doubt implied by reason.

It appears that the use of "reasonable doubt" in an instruction to the jury gained greatly in currency soon after the publication of Judge Shippen's remarks. ${ }^{98}$ It appears in some admiralty hearings and criminal trials, and it was used from the bench in a jury instruction at least before 1793; Chief Justice Kinsey, in a New Jersey capital burglary instruction in 1793, referred to reasonable doubt as a humane measure and described the instruction without a sense of novelty. ${ }^{99}$

Judge May chronicled several usages of the term in Irish treason trials in the $1790 \mathrm{~s},{ }^{100}$ and there were undoubtedly many trials in America that are not well recorded. Even so, there are closing arguments and judicial instructions much more frequently recorded through the 1790s in both England and America, in which jurors were

98 Notwithstanding the occasional instructions of counsel, as in the Boston Massacre cases, it appears that reasonable doubt became common in American courts at about this time. Given the casual manner with which Shippen employed the term "reasonable" relating to doubt, it is most likely that the term had already gained some currency with the American bench as a qualification of doubt. Still, Shippen used "reasonable doubt" in a distinct question before the court, which would suggest it was a current phrase for more than jury verdicts, and not necessarily closely associated with them, a consideration underscored by Justice Wilson's failure to use reasonable doubt in considering jury verdicts in his lectures of the same year. See 2 WILson, supra note 24. Wigmore, the magus of evidence, whose distaste for reasonable-doubt instructions is chronicled below, see infra Part VI.A, also believed the instructions gained currency about this time. See 5 WiCMORE, EvIDENC:, supra note 80, at 464-70.

99 In instructing a jury that convicted the defendant of burglary, leading to a sentence of death, Chief Justice Kinsey remarked,

It is impossible to lay down any general rule, or to declare from what circumstances particular intentions are to be inferred. No two cases are exactly similar, and it is the business of the jury to form their opinion from a serious and deliberate consideration of the facts which appear in the testimony. It is, however, a good rule, and it is also a humane rule, to which every virtuous man will assent, that where reasonable doubts exist, the jury, particularly in capital cases, should incline to acquit rather than condemn.

State v. Wilson, 1 N.J.L. 439, 442 (1793).

100 May, supra note 80, at 656-58. 
charged to acquit if they held any doubts of the defendant's guilt. ${ }^{101}$ Furthermore, the early life of the reasonable-doubt instruction appears to be limited solely to capital trials, ${ }^{102}$ although few trials for such offenses employed it. ${ }^{103}$ There are instances of its use over the next quarter-century, and it was obviously well established by $1850 .^{104}$ Even so, it took some time to enter into the legal imagination as the sine qua non of the criminal juror's obligations.

\section{The Merger of Reasonabl.e Doubt and Moral. Certainty}

In the early years of the nineteenth century, there were three essential forms for talking about the jurors' obligations to acquit-if they had any doubts, if they lacked moral certainty, or if they had reasonable doubts. Certainly, for many writers, lawyers, judges, and jurors, these ideas were synonymous. Even so, it is also evident, if from nothing else than Adams's preference for doubt and Robert Paine's preference for reasonable doubt in the Boston Massacre cases, that prosecutors sought to limit juror doubt to a reasonable doubt.

The synthesis among these three views was, in fact, the replacement of the "any doubt" standard with a hybrid view of moral certainty and reasonable doubt. It came in Thomas Starkie's very successful Evidence, ${ }^{105}$ first printed in London in 1822 and in America two years

101 See cases collected in Morano, supra note 7, at 512. The potential significance of variations among particular formulation of these instructions, which included "beyond a doubt," "beyond all doubt," and "beyond any doubt" is considered in Solan, supra note 5, at 134-42.

102 See 5 Wigmore, Evidence, supra note 80, at 464-65.

103 Most felony cases continued merely to require a verdict from the jury without attempting to limit the juror in how the decision was reached. See, e.g., State v. Pompey, 2 Del. Cas. 113 (Quar. Sess. 1798) (containing the argument of Nicholas Ridgley, Attorney General: "You will, gentlemen, according to the evidence adduced to you find the prisoner either guilty of murder or manslaughter"); State v. Weaver, 3 N.C. (2 Hayw.) 54 (Super. L. \& Eq. 1798) ("If none of these circumstances are to be found in the case, and you are of opinion that the killing with the pistol was with malice aforethought, as before explained, then the prisoner is guilty of murder."); State $\mathbf{v}$. Norris, 2 N.C. (1 Hayw.) 429 (Super. L. \& Eq. 1796) ("The jury will now take the law, the facts, and the circumstances of this case, and by a careful comparison of the one with the other, they will draw a conclusion and say whether the prisoner is guilty of murder or manslaughter.").

104 See Commonwealth v. Webster, 59 Mass. (5 Cush.) 295 (1850); see also infra note 132 and accompanying text.

105 Thomas Starkie, A Pracitical Treatise of the Law of Evidence and Digest of Proofs, in Civil and Criminal Proceebdings (1824). 
later, running through numerous editions. ${ }^{106}$ Starkie inventoried the role and function of various types of testimony and physical evidence that were sufficient to meet various burdens of proof, arguing that each of his rules was reasonable, although he took into account numerous problems of moral proof. ${ }^{107}$ For example, in speaking of proof of a crime by circumstantial evidence, he argued at length for the jury to be required to eliminate all hypotheses of the crime until they had been reduced to the one remaining hypothesis of guilt. The evidence needed to prove circumstances "to a moral certainty," should "exclude every other supposition" by the state. ${ }^{108}$

In speaking of the general criminal verdict based on circumstantial evidence, Starkie said,

What circumstances will amount to proof can never be [a] matter of general definition; the legal test is the sufficiency of the evidence to satisfy the understanding and conscience of the jury. On the one hand, absolute, metaphysical and demonstrative certainty is not essential to proof by circumstances. It is sufficient if they produce moral certainty to the exclusion of every reasonable doubt; even direct and positive testimony does not afford grounds of belief of a higher and superior nature. To acquit upon light, trivial and fanciful suppositions, and remote conjectures, is a virtual violation of the juror's oath, and an offence of great magnitude against the interests of society, directly tending to the disregard of the obligation of a judicial oath, the hindrance and disparagement of justice, and the encouragement of malefactors. On the other hand, a juror ought not to condemn unless the evidence exclude from his mind all reasonable doubt as to the guilt of the accused, and, as has been well observed, unless he be so convinced of the evidence that, he would venture to act upon that conviction in matters of the highest concern and importance in his own interest. . . ${ }^{109}$

This construction equated moral certainty with the absence of reasonable doubt, but it also explicitly defined what doubts are reasonable. Reasonable doubts must be significant, or at least not be doubts that are "light conjectures" or "remote suppositions."

This limited form of doubt by the English barrister troubled his editor, who took care to insert a note between evidence and doubt,

106 See, e.g, Thomas Stakkie, A Practical Treatise of the Law of Evidence (9th Am. ed. from 4th London ed. 1869); Thomas Stakkie, A Practical. Treatise of the LAw of Evidence (George Sharswood ed., 9th ed. 1869).

107 Starkie's antecedents and neo-Lockean edge are described in Theodore Waldman, Origins of the Doctrine of Reasonable Doubt, 20 J. HIST. IDEAs 299 (1959).

108 Thomas Starkie, A Practical Treatise of the Law of Evidence 513 (Benjamin Gerhard ed., 6th ed. 1842) (1837).

109 Id. at $513-14$. 
which told a tale not based on a law report but on a "common report only." 110 It chronicled the story of a servant convicted and executed for the murder of her mistress. The gist of the proof was that defendant and victim were believed to have been alone in a house with locked windows and doors. After the execution, the actual murderers were caught, and one confessed that they had entered through an upper-story window by a board from a nearby building. ${ }^{111}$

Even if this story was offered so as to soften Starkie's point, by such a contrast Starkie's point was even more clearly made: under his formula, the only allowable doubt was reasonable doubt, and reasonable doubt meant only the truly significant, which might not include doubts of true but improbable circumstances.

No longer was certainty equal to a lack of doubt or an absence of doubt by a reasonable person. Moral certainty could only be thwarted by a significant or likely doubt. Starkie also interjected what may have been then a novel procedural element to the juror's conduct. The juror who acts, whether to convict or not to convict, must act with gravity. ${ }^{112}$

Lastly, Starkie maintained the ethical significance of the juror's role, in a manner not too far from the double meaning of Bishop Wilkins's moral certainty: the juror must be satisfied in both "understanding and conscience" that the evidence is sufficient to find guilt. Even with the heightened emphasis on reason, the ethical notion of moral certainty was retained as a basis of practical reason in the juror's decision to act.

Starkie's view of the strength of a doubt necessary to be reasonable was not, however, the only rationalist model of proof. In his famous evidence treatise, Harvard's Simon Greenleaf deliberately built upon Starkie's ideas, among others, in describing the role of reason as demanding an approach between utter credulity and utter skepticism. ${ }^{113}$ While Greenleaf did not refute any of Starkie's language on rational limits of doubt or the bases of reason, Greenleaf was characteristically more circumspect on the origins of belief. For instance, he fleshed out the idea of circumstantial proof by reduction to a sole hypothesis by means that were much more comprehensive in their

\footnotetext{
$110 \quad I d$. at 513 n.c.

111 Id.

112 Id.

1131 Simon Greenleaf, A Treatise on the Law of Evidence 16-17 (Boston, Little, Brown \& Co., 13th ed. 1876) (1842). For a discussion of Greenleaf's influence as a treatise-writer and teacher, see Steve Sheppard, The History of Legal Education in the United States: Commentaries and Primaky Sources 17-18, 348, 620-21 (1999).
} 
evaluation. Indeed, when considering the problem of the sole remaining hypothesis, Greenleaf not only qualified his result but also included instinct among his bases of belief:

This is merely the legal application, in other terms, of a process, familiar in natural philosophy, showing the truth of a hypothesis by its coincidence with existing phenomena. The connections and coincidences, to which we refer may be either physical or moral; and the knowledge of them is derived from the known laws of matter and motion, from animal instincts, and from the physical, intellectual, and moral constitution and habits of man. Their force depends on their sufficiency to exclude every other hypothesis but the one under consideration. Thus, the possession of goods recently stolen, accompanied with personal proximity in point of time and place, and inability in the party charged, to show how he came by them, would seem naturally, though not necessarily, to exclude every hypothesis but that of his guilt. But the possession of the same goods, at a remoter time and place, would warrant no such conclusion, as it would leave room for the hypothesis of their having been lawfully purchased in the course of trade. ${ }^{114}$

From this approach, a bit further elaborated, Greenleaf then merely repeated the by-then standard burdens of proof, that jurors should decide civil cases "in favor of the party on whose sides the weight of the evidence preponderates, and according to the reasonable probability of truth," allowing a deduction from evidence if it "agrees with and supports the hypothesis, which it is adduced to prove." 115

There were considerable obstacles to certainty as a matter of sufficiency in Greenleaf's approach. He emphasized that, although the criminal jury may convict on circumstantial evidence, "it must exclude every other hypothesis but that of the guilt of the party." 116

The criminal jury, however, had a greater task than strictly reconstructing the facts of past events, one that included ensuring that the state, and not the defendant, proved its case:

[b] ecause of the more serious and irreparable nature of the consequences of a wrong decision, the jurors are required to be satisfied, beyond any reasonable doubt, of the guilt of the accused, or it is their duty to acquit him; the charge not being proved by that higher degree of evidence which the law demands. ${ }^{117}$

1141 GreEnleaf, supra note 113, at 15-16.

$115 \mathrm{l}$ id. at 18.

1161 id.

1171 id. 
The jurors' acts were still the basis for justice, which could be wrongly applied.

Following one or another of these formula, many states in the 1830 s and 1840s adopted forms of burdens of proof that required the jury to find guilt beyond a reasonable doubt, ${ }^{118}$ a requirement often made synonymous with finding guilt to a moral certainty. ${ }^{119}$ From this wide variation in instructions and standards, some coalescence occurred following the most famous reasonable-doubt case of the time, written in Massachusetts almost a decade after Massachusetts had adopted a reasonable-doubt rule. ${ }^{120}$

The fame enduring into this century of the 1850 opinion in Commonwealth $v$. Webster spilled over from the eminence of its author, Massachusetts Chief Justice Lemuel Shaw, ${ }^{121}$ but it would have been famous nonetheless. It was a trial for the murder of a well-known financier, George Parkman, a heavyweight Harvard professor, benefactor, and a creditor of Dr. John Webster, the Erving Professor of Chemistry. During an argument in his laboratory over the debt, Webster allegedly hit and killed Parkman with a tree stump and then dismembered the body in a failed attempt to hide it. ${ }^{122}$ The subsequent trial, an "American classic," observed by 60,000 spectators in ten-minute rotations, led to a six-hour jury instruction by Chief Justice Shaw. ${ }^{123}$ Although his instructions were later attacked for their construction of the presumption of malice in homicide cases without a plea of extenuating circumstances, ${ }^{124}$ the portions on reasonable doubt elicited little criticism and have become legendary:

\footnotetext{
118 A skein of cases is collected in Morano, supra note 7, at 520-24.

119 See, e.g., Jones v. State, 14 So. 772, 773 (Ala. 1894) (stating that proof beyond a reasonable doubt and proof to a moral certainty are "legal equivalents"); State v. Staley, 14 Minn. 75, 90-91 (1869) (stating that moral certainty is proof beyond a reasonable doubt).
}

120 See Commonwealth v. Dana, 43 Mass. (2 Met.) 329 (1841).

12] The standard study of Shaw is Leonard W. Levy, The Law of The Commonwealth and Chief Justice Shaw (1957).

122 Webster was said to have confessed after the trial, although the confession was denounced as a fraud, only one of the alterations of the record made to add weight to the verdict against Webster. Alan Dershowitz, Introduction to RePORT OF THE TRIAL OF Professor JoHN W. Webster (1990) (1850). The sensational case has prompted numerous retellings. See, e.g., George Dilnot, The Trial of Professor John White Webster (1928); Robert Sullivan, The Disappearance of Dr. Parkman (1971).

123 Richard B. Morris, Fair Trial 156-203 (1952).

124 See LEV, supra note 121, at 220-28 (describing instruction as just right); Joel Parker, The Law of Homicide, 72 N. AM. L. Rev. 178 (1851) (describing instruction as too lax); id. at 193-94 (describing instruction as too harsh). One reason for the contemporary criticism was the widespread belief, perhaps borne of the strong evidence, 
[W] hat is reasonable doubt? It is a term often used, probably pretty well understood, but not easily defined. It is not mere possible doubt; because every thing relating to human affairs, and depending on moral evidence, is open to some possible or imaginary doubt. It is that state of the case, which, after the entire comparison and consideration of all the evidence, leaves the minds of jurors in that condition that they cannot say they feel an abiding conviction, to a moral certainty, of the truth of the charge. The burden of proof is upon the prosecutor. All the presumptions of law independent of evidence are in favor of innocence; and every person is presumed to be innocent until he is proved guilty. If upon such proof there is reasonable doubt remaining, the accused is entitled to the benefit of it by an acquittal. For it is not sufficient to establish a probability, though a strong one arising from the doctrine of chances, that the fact charged is more likely to be true than the contrary; but the evidence must establish the truth of the fact to a reasonable and moral certainty; a certainty that convinces and directs the understanding, and satisfies the reason and judgment, of those who are bound to act conscientiously upon it. This we take to be proof beyond reasonable doubt. ${ }^{125}$

In this brief moment, Shaw coalesced various strains of thought into what would become the dogma of the standard for the next century. Recognizing the difficulty of the task of definition, he required

that Webster was innocent and wrongly convicted by the jurors, whom Shaw swayed. See Sullivan, supra note 122, at 143-50.

125 Commonwealth v. Webster, 59 Mass. (5 Cush.) 295, 320 (1850). The instructions recorded may not, in fact, have been those Shaw read to the jury. Shaw seems to have edited them heavily. See Dershowitz, supra note 122. The official report is the basis for most all of the later citations to Shaw's opinion, and for this reason its discussion of reasonable doubt appears supra. More likely, Shaw's actual instruction was more terse, although it made essentially the same points. Stone's transcript of the trial records the instruction:

Now, then, Gentlemen, what is reasonable doubt? It is not possible doubt only, because everything is doubtful. It is that doubt which, after the entire consideration of all the evidence has been taken, leaves the Jury uncertain. It is not a mere probability, arising from the doctrine of chances, that it is more likely to be so than otherwise; but a reasonable, moral certainty; that is, a certainty that weighs upon the mind, weighs upon the understanding, satisfies the reason and judgment, that, without leaving any other hypothesis, the facts are such as to implicate the defendant, and do not implicate anybody else. This we take to be proof beyond reasonable doubt; because, if it went beyond that, it if required absolute certainty, as it is of a moral character, this species of evidence would always be insufficient. It is, therefore, that evidence which excludes every other hypothetical, beyond reasonable doubt. Sul.tivan, supra note 122, at 287. Justice Sullivan believed that the Stone transcript was the least revised after the fact among the reports of the trial. Id. at 182. 
doubt to have importance, but its role would remain to preclude the jurors from being morally certain. A reasonable doubt would preclude a guilty verdict, and a failure of the prosecution to "establish the truth of the fact to a reasonable and moral certainty" is proof that a reasonable doubt exists. ${ }^{126}$ A specific reasonable doubt, for Chief Justice Shaw, therefore did not require articulation; reasonable doubt could be had by the failure to convince to a level of certainty as it "directs the understanding." 127

The epistemological significance of this rendering is considerable. The juror's private understanding and conviction was based on evidence that arose to a reasonable and a moral certainty. In this, Shaw might have been equating the moral with the reasonable, and yet such a redundant interpretation is unnecessary. A more plausible rendering is that Shaw was dividing the ethical from the historical senses of Bishop Wilkins's view, that reasonable certainty was the basis for historical understanding and that moral certainty was the basis of the practical foundation ethically to decide to act by finding guilt or innocence.

Reasonable doubt was, in its adolescence, the converse of the sum of both reasonable certainty and moral certainty. There was no particular notion of the scope of the reasonableness which must attend a doubt. Reasonable doubt was the function of the mind that interfered with both historical and ethical certainty, the sum of which was the sentiment of conviction necessary to find guilt. It was no more than a doubt-any doubt-that would be held by a reasonable person.

What distinguished reasonable doubt from all other doubts was precisely that a reasonable person would form the doubt based not on general preoccupations relating to human affairs but upon a consideration limited to the evidence presented in the case at hand. As Justice Shaw put it, the doubt was to be formed, if it was formed, from the context of the case as a whole, a rich matrix of "the entire comparison and consideration of all the evidence." 128 There is no sense in which the juror was required to articulate the nature or premises of the doubt in order to demonstrate its reasonableness.

The juror's task at the time of the Webster case, however cloaked in the luxurious theories of truth from the seventeenth and eighteenth centuries, could be said to be little changed from the task given

126 Webster, 59 Mass. (5 Cush.) at 320.

127 Id.

128 Id. 
the jurors in Dotuman's Case ${ }^{129}$ two centuries earlier, to decide the facts in issue in the case and no others and then to render a decision on guilt or its lack. This similitude is particularly clear when seen in the light of Greenleaf's inclusion of even animal instincts as the basis of belief.

Even so, there are sharp edges to this view, and a close reading of Starkie, or a careful review of the prosecution's use of the terms in the Boston Massacre cases ${ }^{130}$ or Irish Treason trials ${ }^{131}$ suggests a harsher perspective: the juror was being turned from the task of testing the prosecutor's case for sufficient proof of guilt toward the new task of testing the defendant's argument for sufficient proof of doubts.

Moral certainty would remain an important element in defining the burden of proof, the analog of proof beyond a reasonable doubt, throughout the century. It would be used on federal ${ }^{132}$ and state ${ }^{133}$

129 See supra notes 12 \& 21 and accompanying text.

130 See supra note 80 and accompanying text.

131 See supra note 100 and accompanying text.

132 See, for example, Miles \%. Uniled States, 103 U.S. 304, 309 (1881), where the Court upheld the instruction and stated,

Proof beyond a reasonable doubt is such as will produce an abiding conviction in the mind to a moral certainty that the fact exists that is claimed to exist, so that you feel certain that it exists. A balance of proof is not sufficient. A juror in a criminal case ought not to condemn unless the evidence excludes from his mind all reasonable doubt; unless he be so convinced by the evidence, no matter what the class of the evidence, of the defendant's guilt, that a prudent man would feel safe to act upon that conviction in matters of the highest concern and importance to his own dearest personal interests.

Id.; see also Wilson v. United States, 232 U.S. 563 (1914) (approving reasonable-doubt instruction as moral certainty); Perovich v. United States, 205 U.S. 86, 91-92 (1907) (approving circumstantial evidence as a basis for finding no reasonable doubt); Fidelity Mut. Life Ass'n v. Mettler, 185 U.S. 308, 666 (1902) (finding proof to a moral certainty to be equivalent to the concept of reasonable doubt).

133 See Ex parte Taylor, 666 So. 2d 73, 85 (Ala. 1995) (holding that the instruction was not plain error); People v. Stanley, 897 P.2d 481, 500 (Cal. 1995) (holding that "the reasonable-doubt instruction does not constitute error"); Rivers v. State, 484 S.E.2d 519, 514 (Ga. App. 1997) (holding the instruction was not erroneous in context); State v. Hoffman, 851 P.2d 934, 939 (Idaho 1993) (holding instruction did not violate due process); Tobias v. State, 666 N.E.2d 68, 72-73 (Ind. 1996) (holding that council was not deficient for failing to object to instruction); State v. Acree, 916 P.2d 61, 66-67 (Kan. App. 1996) (holding instruction did not violate due process); Evans v. State, 499 A.2d 1261, 1287-88 (Md. 1985) (holding that moral certainty language was comparable to reasonable-doubt standard); Commonwealth v. Hart, 703 N.E.2d 1180, 1181 (Mass. 1999) (holding that the instruction was not erroneous); State v. Moorman, 505 N.W.2d 593, 604-05 (Minn. 1993) (holding instruction sets a higher standard of proof); State v. Kittrell, 678 A.2d 209, 220 (N.J. 1996) (holding that the charge was not unconstitutional); People v. Williams, 675 N.Y.S.2d 445, 446 (App. Div. 
benches for instructing juries, and it would survive appellate and collateral review in the federal courts, ${ }^{134}$ long after the idea of moral certainty had fallen into disuse among both philosophers and general speakers of English.

Of course, to suggest that moral certainty has fallen into disfavor is not to suggest that certainty has done so. In 1982, a committee of the Federal Judicial Conference proposed an instruction, ${ }^{135}$ adopted in $1987,{ }^{136}$ that defined proof beyond a reasonable doubt as being

1998) (holding that moral certainty actually sets a stricter standard than reasonable doubt); State v. Taylor, 455 S.E.2d 859, 862-63 (N.C. 1995) (holding moral certainty instruction was permissible when one of several alternate definitions); State v. Williams, 828 P.2d 1006, 1021 (Ore. 1992) (holding instruction was not reversible error); State v. Desrosiers, 559 A.2d 641, 644 (R.I. 1989) (holding that reasonable doubt could be "properly equated" with proof of guilt beyond a moral certainty); State v. Hallock, 875 S.W.2d 285, 294 (Tenn. Crim. App. 1993) (holding instruction was not erroneous); State v. Cervantes, 942 P.2d 382, 385 (Wash. Ct. App. 1997) (holding that it was "not reasonably likely" that instruction caused jury to apply a lower standard). Compare State v. Bryant, 432 S.E.2d 291, 297 (N.C. 1993) (rejecting instruction of moral certainty as not protecting defendant), with People v. Young, 653 N.Y.S.2d 471, 472 (App. Div. 1997) (rejecting moral and reasonable certainty as not protecting defendant). But see Allman v. State, 571 So. 2d 244, 252 (Miss. 1990) (holding moral certainty instruction misleading).

134 See Austin v. Bell, 126 F.3d 843, 846 (6th Cir. 1997) (holding that the instruction was not unconstitutional); Schneider v. Day, 73 F.3d 610, 611 (5th Cir. 1996) (permitting instruction, as it was "not unconstitutional"); Harvell v. Nagle, 58 F.3d 1541, 1541 (11th Cir. 1995) (holding that any reversible error was "eviscerated by the rest of the jury charge"); United States v. Jacobs, 44 F.3d 1219, 1224 (3d Cir. 1995) (holding it was inadvisable, but not erroneous); Morley v. Stenberg, 25 F.3d 687, 688-89 (8th Cir. 1994) (holding that the instruction was not unconstitutional); United States v. Love, 767 F.2d 1052, 1060 (4th Cir. 1985) (allowing "reasonable moral certainty"); United States v. Drake, 673 F.2d 15, 21 (1st Cir. 1982) ("Standing alone, this language does not constitute plain error."); Odle v. Calderon, $884 \mathrm{~F}$. Supp. 1404, 1417 (N.D. Cal. 1995) (holding that the instruction does not deny due process). But see Victor v. Nebraska, 511 U.S. 1, 10-14 (1994) (holding the instruction was potentially ambiguous); Cage v. Louisiana, 498 U.S. 39, 41 (1990) (holding that moral certainty language is erroneous if used in the wrong context); Gilday v. Callahan, 59 F.3d 257, 263 (1st Cir. 1995) (stating that moral certainty instruction alone may be reversible error); Adams v. Aiken, 965 F.2d 1306, 1311 (4th Cir. 1992) (holding that moral certainty dilutes instruction below due process); Perez v. Irwin, 963 F.2d 499, 502 (2d Cir. 1992) (holding moral certainty instruction was ill-advised, as it may lead to emotional doubt); Morley v. Stenberg, 828 F. Supp. 1413, 1420 (D. Neb. 1993) (instructing jurors "that they may find guilt based upon something other than the factual evidence").

135 Comm. To Study Criminal Jury Instructions, Fed. Judicial Ctr., Pattern Criminal Jury Instructions (1982) [hereinafter FJC Instructions].

136 Subcomm. on Pattern Jury instructions, Judicial Conference of the United States, Pattern Criminal Jury Instructions (1987). 
equivalent to proof that leaves you firmly convinced. ${ }^{137}$ This simple alteration of the then-California-style "moral certainty" into "firm conviction" was both explanatory and in keeping with the original notion of moral certainty. It was also a move that, perhaps inadvertently, again moved American standards of proof more closely into line with twentieth-century English standards ${ }^{138}$ as well as the standards of the civilian world. ${ }^{139}$

\section{The Nineteenth and Twentieth Centuries: Reasonable Doubt Becomes Articulabi.e DoubT}

As the nineteenth century progressed, American culture changed dramatically, and the effects of its change were felt both at the bar and in the jury room. The jury was more democratic. With the opening of

137 FJC InstRUCrions, supra note 135, at 17-18 (1988) (instruction 21), quoted with approval, Victor, 511 U.S. at 27 (Ginsburg, J., dissenting). The instruction is set out in whole in the appendix to this Article.

138 English courts had followed the standard of proof beyond a reasonable doubt since the latter half of the nineteenth century. In 1949, Lord Goddard noted that the principal requirements of a criminal jury are that the jurors "are made to understand that they have to be satisfied and must not return a verdict against a defendant unless they feel sure, and that the onus is all the time on the prosecution and not on the defence, then whether the judge uses one form of language or another is neither here nor there." R. v. Kritz, [1950] 1 K.B. 82, 90 (Ct. Crim. App. 1949) (Lord Goddard, C.J.); see R. v. Summers [1952] 1 All E.R. 1059; R. v. Hepworth, [1955] 2 Q.B. 600 (Lord Goddard, C.J.) This formulation persists, despite criticism. See, e.g., R. v. Kellett [1976] Q.B. 372 CA (Crim. Div.) (Lord Widgery, C.J.) (containing jury instruction of "Are you satisfied beyond any reasonable doubt and so that you are sure?"); $R$. v. Bentley, [2001] 1 Cr. App. R. 21 ("reasonable doubt" or "you are sure" required in instruction). Compare Andrews and Hirst on Criminal Evidence 106-07 (3d ed. 1997) (arguing that instruction to be sure was unhelpful to judges); and A.S. Zuckerman, The Principles of Criminal. Evidence 131(1989) (arguing that "reasonable doubt" is not self-explanatory and that the jurors will not have a common sense of what is required), with JoHn SMITH, CRImINAL Evidence 36 (1995) (arguing that "be sure" instruction upheld in Summers was too lenient).

It should be noted that, notwithstanding Professor Solan's assertions to the contrary, England has not abandoned reasonable doubt altogether but has allowed both instructions to be used. Compare Solan, supra note 5, at 106 (citing Walters v. Queen, 2 App. Cas. 26, 30 (P.C. 1969)), with sources cited supra.

139 French and other continental systems have long applied the rule of in dubio pro reo-"when in doubt acquit." See George P. Fletcher, Two Kinds of Legal Rules: A Comparative Study of Burden-of-Persuasion Practices in Criminal Cases, 77 YALE L.J. 880 (1968). This difference may reflect a greater difference in the Anglo-American reliance on casuistry and reason, which is not as widely shared as we might believe. See George P. Fletcher, Two Modes of Legal Thought, 90 YaLE L.J. 970 (1981); Louis Recaséns-Siches, The Logic of the Reasonable as Differentiated from the Logic of the Rational (Human Reason in the Making and the Interpretation of the Latw), in EsSAYS IN JURISPRUDENCE IN HONOR OF Roscoe Pound 192 (Ralph A. Newman ed., 1962). 
voter lists following the Reconstruction Amendments, the venire now included the poor, Catholics, immigrants, the illiterate, non-whites, and-eventually-even women. ${ }^{140}$

The bar was also changing, in a manner that was at the same time more democratic and more elite. With the advent of a new notion of "legal science," the dominant metaphor of nineteenth-century American law, the law was seen to be both more transparent and predictable, or at least discoverable, and yet the legal savant was just as elite from the laity as ever. ${ }^{141}$ The new lawyer was no longer an oracle but a scientist, and the law could be just as inaccessible to the layman lacking legal scientific knowledge as it had been to the laymen unlearned in the ways of the golden metwand of the common law. Moreover, the lawyers could hardly be expected to presume the new classes of lay jurors properly could acquit themselves in their newfound roles without guidance. The guidance took, then, the forms of legal science, which gave new tools of both explanation and limitation of the juror's function in the criminal trial.

The importation of method from the social sciences, accelerated by the work of Englishmen Jeremy Bentham, John Austin, and, later, Herbert Spencer, led to American criticism of law as a science, and critics in this vein sought to introduce greater predictability and scientific rationalism to the methods of American adjudication. ${ }^{142}$ In the law of evidence, this growing worship of rationalism pervaded the legal treatises, classrooms, and courtrooms of America. ${ }^{143}$ So it is unsurprising that lawyers and judges would attempt to become more specific, more calculable in delineating the role of reasonableness in doubt.

From early on, various lines of cases attempted to locate the doubt that is a reasonable doubt among a variety of linguistic alterna-

140 I am grateful to Albert Alschuler and Tracey Meares for emphasizing for me the importance of growing diversity of the venire, and the potential for a resulting mistrust of the bar of the jury on the growth jury instructions. The rise of the democratic jury is described in Jefreey Abramson, We, The Jury: The Jury System and the IDEAL OF DemOCRACY (1994).

141 See generally M.H. Hoeflich, Law and Geometry: Legal Science from Leibniz to Langdell, in 2 SHEPPARD, supra note 113, at 589; Howard Schweber, Before Langdell: The Roots of American Legal Science, in 2 SHEPPARD, supra note 113, at 606.

142 See, e.g, David Dudley Field, The Magnitude and Importance of Legal Science, in 2 ShEPPARD, supra note 113, at 658; Christopher C. Langdell, Teaching Law As a Science, in 1 SHEPPARD, supra note 113, at 514 .

143 William Twining has suggested that a continuum may be described between the evidentiary theories of the early and later nineteenth century, throughout which an aspiration for reason persisted independent of the degrees to which reason was the basis for decision. See Twining, supra note 54, at 12-18. 
tives. Some of these were designed to define further the idea of reasonable doubt, some to limit or expand the notion. ${ }^{144}$

\section{A. Reasonable Doubts Become Specific and Articulable Doubts}

One strain of development was to emphasize as reasonable the long-standing limits imposed by evidence on the range of inferences that a juror could draw from the evidence. So, for instance, a successful treatise on facts explained that a doubt that is a rational doubt must "spring from and be justified by the evidence alone, to the entire exclusion of all surmises which the jury might entertain of circumstances not contained in the evidence."145 An application of this approach would limit the jury from surmising that someone in possession of stolen goods might have them legally unless there is proof that they had been purchased or been given as a gift. ${ }^{146}$ This was little more than a continuing enforcement of the juror's role as arbiter and not as witness.

A more frequent explanation of reasonableness, and a far greater alteration of its earlier meaning, was the practice of describing reasonable doubts as articulable doubts. Although it may be that every reasonable doubt instruction implies a requirement like articulability, the idea that a juror must be able to state the doubt on which to acquit the defendant goes very far afield from our view of the prosecution having to prove its case to the juror's judgment of certainty. ${ }^{147}$

While the origins of this trial practice are hard to locate precisely, the instruction on articulable doubt appears to have become an accepted legal practice thanks to its deployment by an editor of one of the many posthumous editions of Simon Greenleaf's Evidence. ${ }^{148}$ In

144 Wigmore collects many of these variations. See generally 5 Wigmore, supra note $80 ;$ see also infra note 261.

145 James Ram, A Treatise on Facts As Subject of Inquiry by a Jury 307 (John Townshend ed., 1873).

146 Id. This example is at once both as essential and more simplistic than the similar, if more cautious result posited by Greenleaf. See supra text accompanying note 113 .

147 See supra Part II.C.

148 The author has located one earlier use of the instruction, beginning a long seesaw in Alabama. See, e.g., Cohen v. State, 50 Ala. 108, 111 (1873) (reasonable doubt is "a doubt for which a reason could be given: a probability of the defendant's innocence"), rev'd, Ray v. State, 50 Ala. 104 (1874), reinstated Hodge v. State, 12 S. 164 (Ala. 1893), rev'd, Bodine v. State, 29 So. 926 (Ala. 1901). But see Whitfield v. State, 17 So. 761 (Ala. Ct. App. 1928) (including instruction that reasonable doubt requires a reason not improper). Cohen's instruction, made at the request of the defense, is tantalizingly ambiguous in stating merely "reasonable doubt has been defined." $\mathrm{Co}$ hen, 50 Ala. at 111 . It is not clear whether this is a reference to another source or to 
the fourteenth edition the editors slipped in a footnote to Greenleaf's discussion of reasonable doubt:

Jurists have not been very successful in defining what is a reasonable doubt and are disinclined to be held to any form of words. . . A All the authorities agree that such a doubt must be actual and substantial, as contradistinguished from a mere vague apprehension. An undefinable doubt, which cannot be stated with the reason upon which it rests, so that it may be examined and discussed, can hardly be considered a reasonable doubt, as such a one would render the administration of justice impracticable. ${ }^{149}$

Setting aside the subtle departures from the intent of Greenleaf's original text, this note is a classic of misleading treatise writing. The reader is drawn to believe that the authorities all agree that a doubt that might lead a juror to convict cannot be an "undefinable doubt, which cannot be stated with the reason upon which it rests, so that it may be examined and discussed." Further, there are three nice cases for the proposition, at least, that an "undefinable doubt ... can hardly be considered a reasonable doubt, as such a one would render the administration of justice impracticable." No other authorities had supported this proposition, and the cited three cases had little to do with it.

The three cases cited, Harmon, ${ }^{150}$ Earll, ${ }^{151}$ and Foulke, ${ }^{152}$ all repeat the proposition that a reasonable doubt must be an important doubt. ${ }^{153}$ The opinion closest to the idea that reasonableness requires definition is that of the Philadelphia trial judge in Harmon, who re-

the court's own definition for the jury, but it might suggest an earlier reference, even though none has yet been unearthed by the author.

1493 Simon Greenleaf, A Treatise on the Law of Evidence 33-34 n.a. (Simon Greenleaf Croswell ed., 14th ed. 1883); $c f .3$ Simon Greenleaf, A Treatise on the LAW of Evidence 34-35 (John Henry Wigmore \& Edward Avery Harriman eds., 16th ed. 1899) (cited lines appear only in the fourteenth and fifteenth editions) [hereinafter Greenleaf, Treatise on the Law of Evidence (16TH Ed.)].

150 Commonwealth v. Harmon, 4 Pa. 269 (1846).

151 Earll v. People, 73 Ill. 329 (1874).

152 United States v. Foulke, 6 McLean 349 (Ohio Unrep. Cas. Apr. Term 1855).

153 See Harmon, $4 \mathrm{~Pa}$. at 274 (affirming the conviction of a mother for infanticide on circumstantial evidence when the jury charged that "a doubt, to work an acquittal, must be serious and substantial-not the mere possibility of a doubt"); Earll, 73 Ill. at 333-34. The Earll court affirmed the jury's conviction for abortion when the jury was charged that a

[r]easonable doubt means, in law, a serious, substantial and well-founded doubt, and not the mere possibility of a doubt, and the jury have no right to go outside of the evidence to search for or hunt up doubts (in order to acquit the defendant,) not arising from the evidence or want of evidence.

Earl, 73 Ill. at 333-34; see also infra note 156. 
quired the jury to acquit if the jury "can reconcile [the evidence] to any reasonable hypothesis of innocence. . . . if not, you are bound to say so." ${ }^{154}$ But to require a reasonable hypothesis of innocence in a case based on circumstantial evidence is not the same as to say that all doubts must be definable. ${ }^{155}$ The most outrageous failure of the authority to support this opinion was the cite to Foulke, ${ }^{156}$ in which a jury acquitted a postmaster of stealing money from a letter. The jury was instructed, apparently by U.S. District Judge H.H. Leavit, in wonderful language that had nothing to do with whether the doubts of a juror need be stated:

You, gentlemen, are to judge of the weight of the evidence, and the credibility of the witnesses. There is no tribunal but that before which we must all appear, which can rightly judge of the motives of human action. We have no such standard; and at best, we can only determine matters of controversy, civil and criminal, on the highest probability of facts, from the evidence. But, in every criminal case, where a conviction is utterly ruinous to the accused, a jury will acquit, if they have reasonable doubts of his guilt; but, these doubts must not arise from our sympathies but from a deliberate consideration of the evidence. ${ }^{157}$

The best that might be said of this citation is that the editors of Evidence construed Judge Leavit's use of "deliberate consideration" to mean deliberation among the jurors in their consideration prior to the verdict, rather than a careful consideration of the evidence. There is no reason in Leavit's opinion to accept such a strained reading here, and the idea that the juror must carefully consider the evidence, as we have seen, was much more firmly established in the law.

154 Harmon, $4 \mathrm{~Pa}$. at 274.

155 The problem is a collapse in Harmon of the instruction regarding the isolation of presumptions in cases of circumstantial evidence with the instruction on what can constitute a reasonable doubt. See, for example, Hopt v. Utah, 120 U.S. 430 (1887), in which the trial judge applied both forms of instruction, the circumstantial evidence instruction in language like Harnon's, after which the court began to define reasonable doubt. In Hopt, the jury was charged,

The court charges you that the law presumes the defendant innocent until proven guilty beyond a reasonable doubt. That if you can reconcile the evidence before you upon any reasonable hypothesis consistent with the defendant's innocence, you should do so, and in that case find him not guilty. You are further instructed that you cannot find the defendant guilty unless from all the evidence you believe him guilty beyond a reasonable doubt.

Id. at 439 .

156 Foulke, 6 McLean at 349.

157 I d. at 355 . 
Despite this awkward origin, the note had considerable influence, appearing as it did in the leading American evidence text. It would remain in subsequent editions until Greenleaf's editor became the great Wigmore, who purged it in the place of his own notes, tinted with his hostility to reasonable doubt in general. ${ }^{158}$

The first reported judicial use of an instruction based on the requirement of articulability appears to have been in a widely publicized jury trial, presided over by the Chief Justice of the United States. ${ }^{159}$ In United States v. Butler, ${ }^{160}$ a Ku Klux Klan Act criminal enforcement trial in Reconstruction South Carolina, U.S. Chief Justice Morrison Waite, presiding at the trial, charged the jury that

a reasonable doubt is something more than a captious doubt, a mere vague notion that the accused may be innocent. It must be a doubt for which a reason may be assigned. It need not be a reason sufficient to convince another, but it must be such as may properly influence the mind of one who is honestly endeavoring to perform his solemn duty as juror. ${ }^{161}$

It is rather difficult at this distance to assess Chief Justice Waite's motives in presenting the instruction as requiring that a doubt be a reason that can be stated. Although he did not have a background in the criminal law, we must hesitate to conclude his choice was unintentional. ${ }^{162}$ We cannot ascertain from the record so far even whether he

1583 Greenleaf, Treatise on the Law of Evidence (16TH ed.), supra note 148, at 34-35.

159 There may be earlier examples, although Waite's instruction in Butler appears to have sparked the modern trend. Many cites to the idea begin with either Butler or the later New York case, People v. Guidici. See U.S. v. Searcey, 26 F. 435, 442 (W.D.N.C. 1885) (citing People v. Guidici, 3 N.E. 493 (N.Y. 1885)). But see Cohen v. State, 50 Ala. 108 (1873).

16025 F. Cas. 213 (C.C.D.S.C. 1877). Butler was one of several Klan trials, the sum of which were to eviscerate civil rights enforcement in the United States for the next eighty years. See Lou Falkner Williams, The Great South Carolina Ku Kluux Kian Trials, 1871-1872 (1996).

161 Butler, $25 \mathrm{~F}$. Cas. at 226 . Of the twelve men charged with conspiracy to deprive another of the vote, the jury found one not guilty and failed to agree on the rest, resulting in a mistrial. $I d$.

162 Chief Justice Waite, an Ohioan and graduate of Yale, had represented wealthy corporate and railroad clients before dabbling in politics and being raised to the bench. He was generally unsympathetic to enforcement of the Klan act, as well as to other Reconstruction amendments and statutes, authoring some of the more famous cases limiting the enforcement of the Fourteenth Amendment. See C. Peter Magrath \& Morris R. Waite, The Triumph of Character (1963); Bruce R. Trimble, Chief Justice Waite: Defender of the Public Interest 172 (1938); Richard Claude, Constitutional Voting Rights and Early U.S. Supreme Court Doctrine, 51 J. Necro Hist. 114, 119-24 (1966). 
believed this instruction was helpful to the prosecution or the defense. In any event, Waite was clear in requiring that the reason need not be persuasive to others, merely the person who employs it.

Waite's instruction was echoed verbatim in the same year from the federal district court in Maine, in a criminal action for obstruction of the mail brought against striking union railroadmen. ${ }^{163}$ The instruction was given by the district judge, who emphasized its use by the Chief Justice, ${ }^{164}$ and the instruction was upheld by the circuit court. ${ }^{165}$ Use of the instruction grew slowly but steadily, first in the federal courts, ${ }^{166}$ and then in the states. ${ }^{167}$ By the turn of the century, the states appear to have been almost evenly divided, with roughly half of the states whose appellate courts had considered an instruction requiring a juror to be able to state the doubt rejecting the instruction as misleading. ${ }^{168}$

Of those states that allowed a requirement of articulable doubt, a typical instruction read,

A reasonable doubt, gentlemen, is not a mere possible doubt; it should be an actual or substantial doubt. It is such a doubt as a reasonable man would seriously entertain. It is a serious, sensible doubt, such as you could give a good reason for. It is not sufficient you should believe his guilt only probable. In fact, no degree of probability merely will authorize a conviction, but the evidence must be of such a character and tendency as to produce a moral certainty of the prisoner's guilt to the exclusion of reasonable

163 United States v. Stevens, 27 F. Cas. 1312 (C.C.D. Me. 1877) (No. 16,392).

164 Id. at 1313-14.

165 Id. at 1312.

166 See, e.g., U.S. v. Graham, McKay, 102 F.2d 436 (2d Cir. 1939), cert. denied, 307 U.S. 643, charge quoled in U.S. v. Sussman, 37 F. Supp. 294, 296 (E.D. Pa. 1941); United States v. Jackson, 29 F. 503 (C.C.S.D. Ga. 1886); United States v. Johnson, 26 F. 682, 685 (C.C.D. Ga. 1885) (reasonable doubt "is a doubt that you may entertain, as reasonable men, after a thorough review and consideration of the evidence,-a doubt for which a good reason, arising from the evidence, can be given").

167 See, e.g., Hodge v. State, 12 So. 164 (Ala. 1893); Wallace v. State, 26 So. 713 (Fla. 1899); Vann v. State, 9 S.E. 945 (Ga. 1889); People v. Steubenvoll, 28 N.W. 883 (Mich. 1886); State v. Newman, 101 N.W. 499 (Minn. 1904); People v. Guidici, 3 N.E. 493 (N.Y. 1885); State v. Jefferson, 10 So. 199 (La. 1891); State v. Grant, 105 N.W. 97 (S.D. 1905); Butler v. State, 78 N.W. 590 (Wis. 1899).

168 See, e.g., Roberts v. State, 25 So. 238 (Ala. 1899); Darden v. State, 84 S.W. 507 (Ark. 1905); Siberry v. State, 33 N.E. 681 (Ind. 1893); State v. Cohen, 78 N.W. 857 (lowa 1899); Klyce v. State, 28 So. 827 (Miss. 1900); Cowan v. State, 35 N.W. 405 (Neb. 1887); Morgan v. State, 27 N.E. 710 (Ohio 1891); State v. Morey, 36 P. 573 (Or. 1894). Several of these initial rejections have been reduced by later cases. See, e.g., Stewart v. State, 730 So. 2d 1203 (Ala. Crim. App. 1997); Sulie v. State, 379 N.E.2d 455 (Ind. 1978). 
doubt. The evidence should be such as to satisfy your minds to a certainty, beyond a reasonable doubt, that the accused is guilty of the crime charged, otherwise you should acquit. ${ }^{169}$

The defense in that case had requested an instruction that defined reasonable doubt as grave doubt: "[a] reasonable doubt is not a mere possible doubt; it should be an actual and substantial doubt, not mere possibility or speculation." The Louisiana Supreme Court rejected this instruction, preferring the instruction given, which it said was in keeping with the existing law. ${ }^{170}$ Similar results, while not uniform, were common in state appellate review of similar instructions ${ }^{171}$ and posed no difficulty for federal review. ${ }^{172}$ Occasionally, the articulability standard was even enacted into state statutes, as it was in Oklahoma from 1910 to 1915 , when Oklahoma jurors were told that a reasonable doubt is

a doubt for which there exists a reason in the minds of the jurors, founded upon the facts and circumstances in proof in the case, and is a state of mind of which an ordinarily intelligent man could readily give an explanation, consistent with the facts disclosed by the evidence, and the law, as given to the jury by the court. ${ }^{173}$

There is little question that the nature of these reasonable doubts was, by then, synonymous with the doubts of old, the doubts that would thwart certainty by reasonable people. Indeed, confronted by this precise question, the New Jersey Supreme Court held in somewhat obtuse language that

[the doctrine contends it] is inaccurate to say that a reasonable doubt can exist only when the mind remains unconvinced. This we cannot concede. To us it seems that to be convinced of the exis-

169 State v. Jefferson, 10 So. 199, 200 (La. 1891), quoted and applied in State v. Gould, 395 So. 2d 647, 656 (La. 1980).

170 Id.

171 For cases upholding reasonable doubt as doubt for which a reason can be given, see People v. Grove, 120 N.E. 277, 281 (Ill. 1918) (holding that the instruction requiring "that a doubt must be one that the jury can give a reason for and not a conjured-up doubt" is not wrong); State v. Bailey, 127 A. 589 (N.J. 1925) (reversing earlier cases); State v. Butler, 146 S.E. 418, 419 (S.C. 1929) (holding that the judge's jury instruction defining reasonable doubt as "a doubt for which you can give a sound and substantial reason for" is accurate); State v. Sonnenschein, 159 N.W. 101 (S.D. 1916) (holding that the instruction did not actually require defendant to give reason to each juror); and State v. Overson, 185 P. 364 (Utah 1919). But see Commonwealth v. Weiner, $101 \mathrm{~Pa}$. Super. 295 (1930) (instruction of reason that can be given is error). 172 See, e.g., United States v. Woods, 66 F.2d 262 (2d Cir. 1933); Murphy v. United States, 33 F.2d 896 (3d Cir. 1929), cert. denied, 280 U.S. 584 (1929).

173 OKLahoma Revised Laws $\$ 5876$ (1910), repealed Okla. Sess. Laws 269, quoted in 5 WIGMORE, supra note 80 , at 464 n.1 
tence of a thing and to be satisfied beyond a reasonable doubt of its existence are one and the same condition of mind. ${ }^{174}$

Similar instructions, however, persist to this day in pattern instructions and statutes in some states. Although it is still resisted in some states, ${ }^{175}$ there is, at the close of the century, widespread federal and state acceptance of the idea that reasonableness includes a requirement of articulability. ${ }^{176}$ Of particular interest are cases in South Carolina, which have distinguished instructions for reasonable doubt

174 State v. Leo, 77 A. 523, 525 (N.J. 1910).

175 See, e.g., State v. Banks, 927 P.2d 456 (Kan. 1996) (holding that articulable doubt standard was wrong, but not grounds for a mistrial); Commonwealth v. Thurber, 418 N.E.2d 1253 (Mass. 1981) (holding that articulable doubt standard was not reversible error); State v. Medina, 685 A.2d 1242 (N.J. 1996) (holding that articulable doubt standard was rejected but not reversible error in instruction); State v. Boswell, 294 S.E.2d 287 (W. Va. 1982) (holding that the jury instructions determining reasonable doubt were erroneous because jurors need not articulate reasons for their doubts).

176 See, e.g., Beverly v. Walker, 118 F.3d 900, 904 (2d Cir. 1997) (noting that "good, sound substantial doubt" language should not be used); Chalmers v. Mitchell, 73 F.3d 1262, 1268 (2d Cir. 1996), cert. denied, 519 U.S. 834 (holding that reasonable-doubt instruction was unwise but "not reasonably likely to be misunderstood" by jurors); United States v. Dale, 991 F. 2d 819 (D.C. Cir. 1993), cert. denied, 510 U.S. 906 (finding reasonable-doubt instruction was "sufficient in the context of instructions as a whole"); United States v. Davis, 328 F.2d 864, 867-68 (2d Cir. 1964) (holding that the reasonable-doubt instruction is "not approved" and "perhaps unwise," but "not erroneous"); Barber v. Scully, 557 F. Supp. 1292, 1296 (S.D.N.Y. 1983) (holding that the instruction on reasonable doubt was not constitutionally defective); Robinson v. Callahan, 694 F.2d 6, 7 (1st Cir. 1982) (holding that the instruction on reasonable doubt was not a constitutional error); Jenkins v. State, 627 So. 2d 1034, 1048 (Ala. Crim. App. 1992) (holding that the instruction defining reasonable doubt as "a doubt for which reason can be assigned" is not erroneous); State v. Lewis, 717 A.2d 1140, 1160 (Conn. 1998) (holding that the definition of reasonable doubt as "a doubt for which a valid reason may be assigned" is not erroneous); Lawson v. State, 402 S.E.2d 344, 345 (Ga. 1991) (holding that the reasonable-doubt instruction is not favored but not reversible error); Robbins v. State, 532 S.E.2d 127, 131 (Ga. App. 2000) (holding that instruction of a "doubt that can be given" upheld); Sulie v. State, 522 N.E.2d 380, 384 (Ind. 1988) (holding that the instruction of "a doubt for which a reason may be given" was upheld); State v. Whipple, 476 S.E.2d 683, 687 (S.C. 1996) (stating that the juror must be able to give reason); People v. Maldonado, 631 N.Y.S.2d 850, 852 (App. Div. 1995), app. denied, 663 N.E.2d 1264 (N.Y. 1995) (holding that instruction that a reasonable doubt is "a doubt based upon reason, and it is a doubt for which a juror can give a reason if he or she is called upon to do so in the jury room" is appropriate); State v. Ferola, 534 A.2d 173, 176 (R.I. 1987) (holding that reasonable-doubt instruction of "a doubt founded in reason, a doubt to which you can assign a logical and sound reason and not a doubt arising out of whimsy or caprice" was upheld); State v. Bembenek, 331 N.W.2d 616, 628 (Wis. 1983) (holding that the reasonable-doubt instruction was free from error). 
as acceptable from forbidden instructions requiring a juror to rely on a "real reason." 177

The requirement that a doubt be articulable, that a juror be able to explain a doubt in order to hold a reasonable doubt, has created a distinct dynamic of what type of reason can be assigned successfully. The need to assign a doubt implies that a generic doubt would be insufficient, such as "I doubt the prosecutor's case." Such a doubt would strike many hearers of the instruction as too broad or diffuse to be anything more than a mere doubt or a speculative doubt, and not one that "you can give a good reason for." Thus, a doubt must be focused upon either a specific insufficiency in a prosecutor's case, or upon a specific proposition in the defense's case.

An inherent difficulty with an articulability requirement of doubt is that it lends itself to reduction without end. If the juror is expected to explain the basis for a doubt, that explanation gives rise to its own need for justification. If a juror's doubt is merely, "I didn't think the state's witness was credible," the juror might be expected to then say why the witness was not credible. The requirement for reasons can all to easily become a requirement for reasons for reasons, ad infinitum. ${ }^{178}$

One can also see a potential for creating a barrier to acquit for less-educated or skillful jurors. A juror who lacks the rhetorical skill to communicate reasons for a doubt is then, as a matter of law, barred from acting on that doubt. This bar is more than a basis for other jurors to reject the first juror's doubt. It is a basis for them to attempt to convince that juror that the doubt is not a legal basis to vote for acquittal. ${ }^{179}$

A troubling conclusion that arises from the difficulties of the requirement of articulability is that it hinders the juror who has a doubt based on the belief that the totality of the evidence is insufficient. Such a doubt lacks the specificity implied in an obligation to "give a reason," an obligation that appears focused on the details of the arguments. Yet this is precisely the circumstance in which the rhetoric of

177 See State v. Clute, 480 S.E.2d 85, 90 (S.C. Ct. App. 1996) (upholding a reasonable-doubt instruction as "a doubt for which a reason can be given"), cert. denied, 522 U.S. 982 (1997); State v. Kirkpatrick, 462 S.E.2d 884, 889-90 (S.C. Ct. App. 1995) (same), distinguishing State v. Manning, 409 S.E.2d 372 (S.C. 1991) (barring instruction that defined reasonable doubt in terms of "moral or grave certainty" or a "real reason"). Older cases on this point may be found in H.D. Warren, Annotation, Use of the Term "Actual Doubt" in Instruction on Reasonable Doubt, 147 A.L.R. 1046 (1943).

178 I am grateful to Jeremy Waldron for this illustration.

179 For this point, I am thankful to Ed Imwinkelreid. 
the law, particularly the presumption of innocence and the state burden of proof, require acquittal. ${ }^{180}$

\section{B. Articulability Encouraged by the Pressure of the Advocates and by Confusion with Other Rules}

It is unsurprising that the requirement that a reasonable doubt be an articulable doubt is popular not only with prosecutors but also with the federal bench. Two distinct pressures keep alive this approach in the nation's juries.

The first is the very simple desire of prosecutors to diminish the burden of proof. The prosecutor, who is confronted by a requirement of proving beyond a reasonable doubt, is very likely to emphasize to each juror that there are doubts about doubts. Not all doubts are strong enough to be "reasonable." An easy demarcation for the prosecutor to deploy is, at a minimum, a reasonable doubt must be one the juror can describe aloud. This demarcation is deployed, sometimes at voir dire ${ }^{181}$ and often in closing arguments. ${ }^{182}$

There is another, unrelated phenomenon supporting the idea that a reasonable doubt should be subject to the assignment of reasons. The test, reasonable doubt-and for that matter its near-corollaries, reasonable belief and reasonable suspicion-are in constant use by the bench in other considerations. In all of the many ways in which a judge employs such terms to assess judicial determinations, reasons must be assigned. Thus, judges must assign reasons for concluding that an error in a trial, if it had not occurred, would not have interfered in a jury's finding guilt beyond a reasonable doubt. Moreover, the standard is often applied in the review of a criminal trial, in

180 Even though I thought this one up myself, I still think it is correct. I grew bolstered in this view when I encountered the observations of Justice Marshall in Adams v. South Carolina, 464 U.S. 1023, 1026 (1983) (Marshall, J., dissenting), and Butler v. South Carolina, 459 U.S. 932 (1982) (Marshall, J., dissenting). See also infra note 239 and accompanying text.

181 See, e.g, State v. Robertson, 712 So. 2 d 8 (La. 1998); McGregor v. State, 885 P.2d 1366 (Okla. Crim. App. 1994).

182 See, e.g., Hall v. State, 820 So. 2d 113 (Ala. Crim. App. 1999), affd, Ex parte Hall, No. 1990373, 2001 WL 586952 (Ala. June 1, 2001); Brown v. State, 663 A.2d 583 (Md. Ct. App. 1995); Lord v. State, 806 P.2d 548 (Nev. 1991); State v. Gonzales, 817 P.2d 1186 (N.M. 1991). While many reported appellate opinions contain similar comments, these arguments are rarely grounds for appeal or reversal because in most states they reflect the law. Therefore such closing comments are much more often made than are grounds for appeal. It is the opinion of the author that the closing argument of what is not a reasonable doubt is a prosecutor's stock in trade in most jurisdictions. 
which the judge must assess beyond a reasonable doubt that there is error.

The reasons assigned in this manner to judicial findings are the basis for appellate and collateral review of the relationship between the premises found and conclusions reached below. On the other hand, this enterprise should be of little effect on jurors' rationales, because their findings, particularly in a general verdict, are not subject to a similarly detailed appeal.

There is also the confusing relationship between reasonable doubt and reasonable belief. Reasonable belief is, of course, used in countless areas of the law. A police officer making a warrantless search must have a reasonable suspicion that the search will yield evidence of a particular crime. ${ }^{183}$ A police officer or other person must have a reasonable belief that a life is in danger in order to use deadly force. ${ }^{184}$ A reasonable belief of consent remains a defense to a charge of rape. ${ }^{185}$ Reasonable belief has a significant role in private law ${ }^{186}$ and civil procedure. ${ }^{187}$

In all of these roles, "reasonable" connotes a very different modification of its other nouns than it does to "doubt," at least as doubt began its journey through criminal jury instructions. Reasonableness in American law generally connotes an objective standard that can be the basis for a similar understanding by any rational person, as one sees in both standards of care in tort and their reliable predecessor, the "reasonable man." 188 Reasonableness in this sense answers the question of whether good judgment is exercised, according to a host of variables and not according to whether a reason can be assessed for the result. In this sense, reasonableness still resonates with the form of "reasonable" as a description of doubts that undermines moral certainty. Such reasonable doubts were doubts of reasonable people; prudent concerns that had gravity but not necessarily a distinct and

183 United States v. Arvizu, 534 U.S. 266 (2002); Terry v. Ohio, 392 U.S. 1, 30 (1968).

184 See, e.g., People v. Barnett, 954 P.2d 384 (Cal. 1998).

185 See Dana Berliner, Note, Rethinking the Reasonable Belief Defense to Rape, 100 YaLE L.J. 2687 (1991).

186 Restatement (SECOND) OF TORTS $\$ 388$ (1965) (making one subject to liability for supplying a chattel for another to use if the supplier "knows or has reason to know that the chattel is or is likely to be dangerous for the use for which it is supplied").

187 Kobzoff v. L.A. County Harbor, 968 P.2d 514 (Cal. 1998) (construing CAL. Crv. Proc. $\$ 1038$ ).

188 See, e.g., Restatement (Second) of Torts $\$ 11$; Randy T. Austin, Comment, Better Off with the Reasonable Man Dead or the Reasonable Man Did the Damdest Things, 1992 B.Y.U. L. Rev. 479. 
articulable form. Neither form of reasonableness, however, has otherwise been reduced to being equated with having reasons.

Granted, one method by which reasonableness is often ascertained is to consider the variables, the circumstances, indeed the reasons for the judgment. But this method is never sufficient, and the inquiry in other areas of the law remains that reasonableness is to be determined by the totality of the circumstances. ${ }^{189}$

It is possible, of course, that lawyers and judges are so thoughtful and well educated as to keep apart the sense of reasonableness from a judgment based upon reasons. Even so, in the rush of a busy docket, it is also possible that the idea of reasonableness as an objective and articulable basis of decision may sometimes be confused with the idea of reasonableness as a matter of prudent concern.

If such confusion does arise, it is then not unsurprising that judges in its grip will find no difficulty in asserting that a reasonable doubt held by a juror should be analogous to a reasonable belief by a policeman, a defendant in tort, or a judge: it should be articulable. A juror with a reasonable doubt should be able to describe it as a judge could; otherwise, the juror simply has a doubt and not a reasonable one.

\section{The Twentieth Century: Reasonable Doubt Enshrined- Or Petrified}

The morass of state instructions on reasonable doubt acquired even greater complexity when the U.S. Supreme Court announced that criminal defendants have a constitutional guaranty not to be convicted by any lesser standard. The interesting effect of the federal interposition into the already messy arena of the state instructions has been, perhaps, contrary to the Court's expectations. Rather than giving greater protection to defendants, the Court has hastened the demise of many of the remaining protections that had persisted despite the diminished standards of reasonable doubt. ${ }^{190}$

189 See, e.g., United States v. Arvizu, 534 U.S. 266 (2002) (examining totality of the circumstances to determine reasonable suspicion for police stop); Overnite Transp. Co. v. NLRB, 280 F.3d 417 (4th Cir. 2002) (examining totality of the circumstances to determine unfair labor practices). The concept of totality of the circumstances is itself an outgrowth of the now somewhat obsolete notion of the reasonable man.

190 For the general conclusion that instructions seeking proof beyond a reasonable doubt lessened the burden on the state from the older standards of juror certainty, see Morano, supra note 7 , at 527-28. 


\section{A. Reasonable Doubt Becomes Constitutionally Enshrined, and Moral Certainty Takes a Beating}

In 1970, a majority of the U.S. Supreme Court accepted Justice Brennan's position that the Due Process Clause of the Fourteenth Amendment protects the accused in a criminal action from conviction unless guilt is found beyond a reasonable doubt. ${ }^{191}$ In that case, In re Winship, New York had set a standard for juvenile criminal proceedings for adjudications of guilt by "a preponderance of the evidence."192 Although recognizing special limitations in cases regarding children, Justice Brennan considered the wider range of state obligations of fairness in criminal trials. In that light, he asserted that the requirement of proof beyond a reasonable doubt gives a citizen "confidence that his government cannot adjudge him guilty of a criminal offense without convincing a proper factfinder of his guilt with utmost certainty." 193 Thus he found "constitutional stature" for a right of "the accused against conviction except upon proof beyond a reasonable doubt of every fact necessary to constitute the crime with which he is charged." 194

In reaching this conclusion, there is no evidence that the Court considered other, higher standards; particularly, there is no indication that the Court considered the idea of reasonable doubt as a lesser standard than the standard of certainty that was once offered to the defendants in American courts. Indeed, Justice Brennan not only equated "utmost certainty" with "proof beyond a reasonable doubt," but he also quoted an article for the proposition that "the reasonabledoubt standard is indispensable, for it impresses on the trier of fact the necessity of reaching a subjective state of certitude of the facts in issue." 195 That this equivalence might not, even then, be fully the case seems not to have occurred to him.

Thus, the reasonable-doubt standard entered the constitutional pantheon with little consideration either of the operation of the stan-

191 In re Winship, 397 U.S. 358 (1970). Justice Black, in a formidable dissent, relied largely on historical grounds to assert that nothing in the Due Process Clause suggests that state legislatures lack the authority to set the burden of proof in their proceedings. Of course, this approach does not necessarily imply a lesser authority of the state courts to set such a standard. Interestingly, Justice Black believed that the reasonable-doubt standard had "long been required" in federal criminal trials; it had then been required for about a century. See id. at 385 (Black, J., dissenting).

192 Id. at 360.

193 Id. at 364 .

$194 \mathrm{Id}$.

195 Id. (quoting Norman Dorsen \& Daniel A. Rezneck, In re Gault and the Future of Juvenile Law, 1 FAM. L.Q. 4, 26 (1967)). 
dard itself or of alternative standards that might give similar or greater protection to defendants, and with no consideration of the effect of the instruction on jurors and officials. It is, indeed, possible to consider the eighteenth-century American innovation of jury trial to suggest that a high burden of proof is essential to our constitutional principle of ordered liberty. Still, the Court did not consider that such a burden of proof not only would have differed from the standard of "reasonable doubt" but also would likely have been more protective of a defendant than reasonable doubt. ${ }^{196}$

At least in part, a failure to grasp fully the many forms of conflict among the ideas reflected in "reasonable doubt" and its alter egosparticularly "moral certainty" and "certainty"-has led the Court in two recent opinions to strike even more deeply against the requirement of juror certainty. In Cage $v$. Louisiana ${ }^{197}$ and Victor $v$. Nebraska, ${ }^{198}$ the Supreme Court finally entered the tournament lists of reasonable doubt, not only joining the perennial game of attempting to define reasonable doubt but also attempting to refine its own standards to which it will hold other courts in the same tourney. ${ }^{199}$ In

196 The author does not assert that principles of ordered liberty are the sole basis for the identification or recognition of federal constitutional rights. It does seem odd, though, for the Court to adopt standards that would give less protection to the citizen. The idea of ordered liberty as a basis for interpreting due process is, of course, strongly associated with the second Justice Harlan. See Duncan v. Louisiana, 391 U.S. 145, 176-77 (1968) (Harlan, J., dissenting); Memoirs v. Massachusetts, 383 U.S. 413, 458 (1966) (Harlan, J., dissenting); Griffin v. California, 380 U.S. 609, 616-17 (1965) (Harlan, J., concurring); Malloy v. Hogan, 378 U.S. 1, 28 (1964) (Harlan, J., dissenting); see also Palko v. Connecticut, 302 U.S. 319, 325-26 (1937) (Cardozo, J.) (holding that the Fourteenth Amendment protects rights "implicit in the concept of ordered liberty").

197498 U.S. 39 (1990) (per curiam).

198511 U.S. 1 (1994).

199 There had been, of course, earlier criticisms of instructions, on which the opinion of the Court had not turned, mainly notices of criticism of similar instructions by other federal courts. See, e.g., Jackson v. Virginia, 443 U.S. 307, 317, 321-22 (1979) (noting that "reasonable doubt, at a minimum, is one based upon reason. Yet a properly instructed jury may occasionally convict when it can be said that no rational trier of fact could find guilt beyond a reasonable doubt"); Addington v. Texas, 441 U.S. 418,428 (1979) (noting that the reasonable doubt standard is a "unique standard of proof not prescribed or defined in the constitution"); Taylor v. Kentucky, 436 U.S. 478,488 (1978) (criticizing the trial court real doubt instruction as a "a substantial doubt, or real doubt" as being "hardly a model of clarity"). In an echo of two different judicial senses of reasonableness, the Court has specified that its review of an ambiguous instruction is based on "whether there is a reasonable likelihood that the jury has applied the challenged instruction in a way" that violates the Constitution. Boyde v. California, 494 U.S. 370, 380 (1990); see also Estelle v. McGuire, 502 U.S. 62, 72 n.4 (1991). 
Cage, the Court struck down a Louisiana instruction that defined reasonable doubt as

one that is founded upon a real tangible substantial basis and not upon mere caprice and conjecture. It must be such doubt as would give rise to a grave uncertainty, raised in your mind by reasons of the unsatisfactory character of the evidence or lack thereof. A reasonable doubt is not a mere possible doubt. It is an actual substantial doubt. It is a doubt that a reasonable man can seriously entertain. What is required is not an absolute or mathematical certainty, but a moral certainty. ${ }^{200}$

The Court reversed the Louisiana Supreme Court's allowance of the instruction, singling out the elements of the definition equating reasonable doubt with "grave uncertainty" and "actual substantial doubt," and requiring jurors to have "moral certainty" of guilt. ${ }^{201}$ The per curiam opinion noted, "It is plain to us that the words 'substantial' and 'grave,' as they are commonly understood, suggest a higher degree of doubt than is required for acquittal under the reasonabledoubt standard." ${ }^{202}$ These concerns were compounded by the traditional reference to moral certainty. In a twist that suggests more than it clarifies, the Court compared the traditional level of certainty based on evidence of the senses to something new, "evidentiary certainty": " $[w]$ hen those statements are then considered with the reference to 'moral certainty,' rather than evidentiary certainty, it becomes clear that a reasonable juror could have interpreted the instruction to allow a finding of guilt based on a degree of proof below that required by the Due Process Clause." 203 As a result of the finding of constitutional infirmity in the instruction, Cage's execution was stayed, although the state supreme court found that the discredited instruction was harmless error, ${ }^{204}$ after which the U.S. Supreme Court announced that infirm reasonable-doubt instructions are always harmful error, ${ }^{205}$ and a new trial was ordered. 206

In 1994, the Court revisited the problems of reasonable doubt in Victor $v$. Nebraska, ${ }^{207}$ a consolidated case considering jury instructions from California and Nebraska. Arthur Sandoval had been convicted

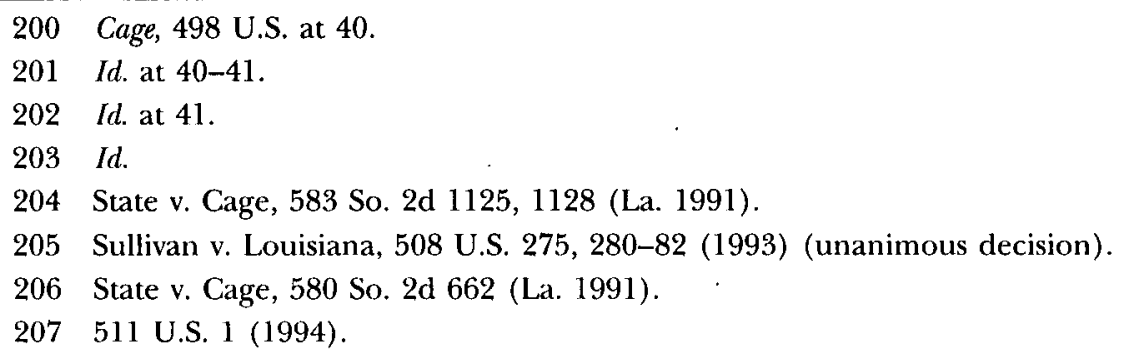


of a gang-related double homicide. ${ }^{208}$ His jury was instructed using California's standard instruction, following Chief Justice Shaw's use of moral certainty:

Reasonable doubt is defined as follows: It is not a mere possible doubt, because everything relating to human affairs, and depending on moral evidence, is open to some possible or imaginary doubt. It is that state of the case which, after the entire comparison and consideration of all the evidence, leaves the minds of the jurors in that condition that they cannot say they feel an abiding conviction, to a moral certainty, of the truth of the charge. ${ }^{209}$

A Nebraska jury acted on similar instructions to convict Clarence Victor, a gardener accused of beating and then cutting the throat of his 82-year-old, part-time employer:

"Reasonable doubt" is such a doubt as would cause a reasonable and prudent person, in one of the graver and more important transactions of life, to pause and hesitate before taking the represented facts as true and relying and acting thereon. It is such a doubt as will not permit you, after full, fair, and impartial consideration of all the evidence, to have an abiding conviction, to a moral certainty, of the guilt of the accused. At the same time, absolute or mathematical certainty is not required. You may be convinced of the truth of a fact beyond a reasonable doubt and yet be fully aware that possibly you may be mistaken. You may find an accused guilty upon the strong probabilities of the case, provided such probabilities are strong enough to exclude any doubt of his guilt that is reasonable. A reasonable doubt is an actual and substantial doubt reasonably arising from the evidence, from the facts or circumstances shown by the evidence, or from the lack of evidence on the part of the State, as distinguished from a doubt arising from mere possibility, from bare imagination, or from fanciful conjecture. ${ }^{210}$

Both Sandoval and Victor complained that these instructions violated the standards of Winship ${ }^{211}$ and Cage, ${ }^{212}$ essentially because the jury could find that guilt on a standard lower than the level required by due process, which by then obligated the jury to find the state has proven its case beyond a reasonable doubt. They argued that the jury could find moral certainty at a lower threshold, that the jury might rely on ideas other than evidence in the case to form moral certainty, that jurors might exclude "mere possible doubts" that should be avail-

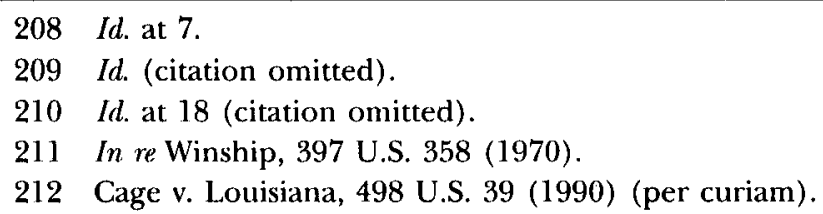


able to them, and particularly in Victor's case, that the requirement of "substantial doubt" lowered the state's standard. 213

Justice O'Connor, for the majority, cursorily reviewed the history of jury instructions, beginning with the Webster opinion, and concluded that Sandoval's and Victor's claims were groundless either because there was no reasonable likelihood of the jury's mistaking its task, or because there were alternative definitions of reasonableness to cure any mistaken notions in the instructions. Particularly as to the linkage of moral certainty with reasonable doubt, she said, "there is no reasonable likelihood that the jury would have understood moral certainty to be disassociated from the evidence in the case." ${ }^{14}$ Further, and rejecting arguments both on its nineteenth-century meaning and its current usage, she stated, "We do not think it reasonably likely that the jury understood the words 'moral certainty' either as suggesting a standard of proof lower than due process requires or as allowing conviction on factors other than the government's proof."215 Thus, moral certainty is not constitutionally forbidden from use as an understanding of the state's burden of proof to the jury. Justice O'Connor continued,

At the same time, however, we do not condone the use of the phrase. As modern dictionary definitions of moral certainty attest, the common meaning of the phrase has changed since it was used in the Webster instruction, and it may continue to do so to the point that it conflicts with the Winship standard. ${ }^{216}$

This consideration of the dictionary usage as a basis for determining the meaning of the standard of proof, is, in some regard, problematic. Although she considered the etymological transitions of the meaning of "moral certainty," it is interesting to note that she did not consider a similar examination of a parallel evolution of the meaning of "reasonable." Moreover, the very fact of resort to a dictionary suggests the intersection of the lay vocabulary with legal arcana. ${ }^{217}$

In short, the majority of the Court considered the instructions to be questionable. ${ }^{218}$ Even so, the convictions were not overturned. ${ }^{219}$

\footnotetext{
213 Victor, 511 U.S. at 14-22.

214 Id. at 16.

215 Id.

216 Id.

217 For these points, I am grateful to the insights of Philip Hamburger and Dick Helmholz.

218 Justices Kennedy and Ginsburg each concurred, emphasizing their concerns over the language of the instructions:

Though the reference to "moral certainty" is not much better, California's use of "moral evidence" is the most troubling, and to me seems quite in-
} 
Justice Blackmun, joined by Justice Souter, dissented, arguing that the instruction was too similar to that struck in Cage to be distinguished. ${ }^{220}$ Further, he argued that the use in the instruction of "grave" and "substantial" doubt and of "strong probabilities," as well as language about moral certainty and the hesitation to act, not only were likely to confuse jurors but also were likely to overstate the degree of doubt required to acquit.221

Despite disagreement on similarities between the allowed Victor and disallowed Cage instructions, the one point on which all of the opinions were agreed was that "moral certainty" was confusing and ought to be removed. Indeed, lower courts considering similar instructions have begun reaching exactly this conclusion. ${ }^{222}$ Thus, it is perhaps unsurprising to find that California has modified its pattern

defensible. The derivation of the phrase is explained in the Court's opinion, but even with this help the term is a puzzle. And for jurors who have not had the benefit of the Court's research, the words will do nothing but baffle.

Id. at 23 (Kennedy, J., concurring). Justice Ginsburg stated, "I agree, further, with the Court's suggestion that the term 'moral certainty,' while not in itself so misleading as to render the instructions unconstitutional, should be avoided as an unhelpful way of explaining what reasonable doubt means." Id. at 24 (Ginsburg, J., concurring in part and concurring in the judgment).

219 This was not the first time the Court had reached this result. Justice Stephen J. Field, in Hopl v. Ulah, 120 U.S. 430 (1887), had concluded that there was no real difference between moral certainty and reasonable doubt in the instruction, but the Court did not strike it down. His argument of the idea he believed to which each was proxy is instructive:

The instruction in the case before us is as just a guide to practical men as can well be given; and if it were open to criticism it could not have misled the jury, when considered in connection with the further charge, that if they could reconcile the evidence with any reasonable hypothesis consistent with the defendant's innocence they should do so, and in that case find him not guilty. The evidence must satisfy the judgment of the jurors as to the guilt of the defendant, so as to exclude any other reasonable conclusion.

Id. at 441 .

220 Victor, 511 U.S. at 28, 31-33 (Blackmun, J., concurring in part and dissenting in part).

221 Id. at 33-34 (Blackmun, J., concurring in part and dissenting in part).

222 See, for example, Morris v. Cain, 186 F.3d 581, 586 (5th Cir. 1999), in which the court granted habeas, applying Cage and Victor to overturn this instruction:

However, this doubt must be a reasonable one, that is, one that is founded upon a real, tangible, and substantial basis and not upon mere caprice, fancy or conjecture. It must be such a doubt as would give rise to a grave uncertainty raised in your mind by reason of the unsatisfactory character of the evidence or the lack thereof. A reasonable doubt is not a mere possible doubt. It is an actual or substantial doubt. It is a doubt that a reasonable man would seriously entertain. What is required is not an absolute or mathematical certainty but a moral certainty. 
instructions in Victor's wake, removing moral certainty from the charge. ${ }^{223}$ It is likewise unsurprising that the lower courts have continued to disagree on the constitutional sufficiency of various formulæ of reasonable doubt, particularly those dealing with moral certainty. ${ }^{224}$ The confusion is, if anything, even greater in considering the role of articulability.

\section{B. The Difficulties of Articulability Continue}

If the differences between Cage and Victor illustrate nothing else, they are stark reminders of the small variants in definitions of reasonable doubt that alter the result for a majority on the Court. But the Court is not the only source of our understandings of "reasonable," and the term enjoys a wide play in the culture.

In this century's culture, as much as in the Court, there has been drift in the language. When someone says "that is reasonable," it is now less likely that this person means "that is a good judgment" or "that is based on the faculty of reason." "That is reasonable" often now means "I see you have your reasons."

In the realms of both law and popular usage, a strong linkage continues between reason and identification, such that a reasonable doubt must be identifiable, quantifiable, and at the least articulable. A contrary approach continues to find adherents to a view that asserts reasonableness is incapable of further definition, resisting the tug to relate the reasonable as the articulable. Thus, while articulability as a requirement of reasonable doubt has generally succeeded in American evidentiary, criminal, and constitutional law, there is a split in the circuits on this issue.

In Vargas $v$. Keane, ${ }^{225}$ the Second Circuit upheld an instruction that described reasonable doubt as "doubt for which you can give a

Id., discussed in Marty Solomon, Note, Morris v. Cain: The Fifth Circuit Sidesteps the AEDPA and Strikes Doun a Reasonable Doubt Jury Instruction, 74 TUL. L. REv. 1153 (2000).

223 See 2 Comm. on Standard Jury Instructions, Criminal, of the Superior Court of Los Angeles County, Cal., Part 17, Concluding Instructions G., Concluding Instructions (i) Restitution and Verdict, Appendix B Reasonable Doubt-The California Experience (1996), in California Jury Instructions-Criminal. (6th ed. 1996).

224 Compare Schneider v. Day, 73 F.3d 610 (5th Cir. 1996) (holding moral certainty instruction not unconstitutional), and Harvell v. Nagle, 58 F.3d 1541 (11 th Cir. 1995) (same), with Simpson v. Matesanz, 29 F. Supp. 2d 11 (D. Mass. 1998) (holding moral certainty instruction unconstitutional), and Austin v. Bell, 938 F. Supp. 1308 (M.D. Tenn., 1996) (same).

22586 F.3d 1273 (2d Cir. 1996). 
reason if called upon to do so by a fellow juror in the jury room."226 The court, however, came to the interesting conclusion that, when viewed in context, the language of the instruction "simply does not suggest that a doubt formulated within one's own mind-reasonable, but not articulable-is insufficient for acquittal."227

Despite its efforts to construe away a conflict in the circuits, the Fifth Circuit en banc split with the Second Circuit. In Humphrey $v$. Cain, ${ }^{228}$ the circuit doing the most business in death cases rejected an instruction that required jurors to think of reasonable doubt as

one founded upon a real, tangible, substantial basis, and not upon mere caprice, fancy or conjecture. It must be such a doubt as would give rise to a grave uncertainty, raised in your minds by reason of the unsatisfactory character of the evidence; one that would make you feel that you had not an abiding conviction to a moral certainty of the defendant's guilt. If, after giving a fair and impartial consideration to all of the facts in the case, you find the evidence unsatisfactory upon any single point indispensably necessary to constitute the defendant's guilt, this would give rise to such a reasonable doubt as would justify you in rendering a verdict of not guilty. . . . A reasonable doubt is not a mere possible doubt. It should be an actual or substantial doubt. It is such a doubt as a reasonable man would seriously entertain. It is a serious doubt, for which you could give good reason. ${ }^{229}$

The three-judge panel found that the instruction "lightens the state's burden and removes a substantial protection assured defendants," ${ }^{330}$ and the panel's reasoning was adopted by a majority of the court en banc. ${ }^{231}$ A dissent from the en banc ruling, filed by Judge Edith Jones and three of her colleagues, including the redoubtable Judge E. Grady Jolly, Jr., argued that this instruction held neither of the two vices that render a reasonable-doubt instruction unconstitu-

226 Id. at $1277-79$.

227 Id at 1278 . The Second Circuit had previously upheld an instruction demanding articulability: "a doubt for which some good reason can be given." Chalmers v. Mitchell, 73 F.3d 1262, 1266 (2d Cir. 1996). But see Chief Judge Newman's dissent, id. at 1274-76 (Newman, C.J., dissenting) (criticizing the instruction).

228120 F.3d 526 (5th Cir. 1997), vacated, 138 F.3d 552 (5th Cir. 1998) (en banc), cert. denied, 525 U.S. 935, 943 (1998) (supporting the reasoning of the three-judge panel, but adopting a different reasoning and overruling precedent).

229 Humphrey, 120 F.3d at 528.

$230 I$ Id. at 530.

231 Humphrey ข. Cain, 138 F.3d 552 (1997) (en banc). For a later application, see Tyler v. Cain, No. 97-G1549, 1998 U.S. Dist. LEXIS 14591, at *5-6 (E.D. La. Sept. 8, 1998) (giving the same jury instruction as in Humplrey, but the application was filed too late to apply Humphrey precedent). 
tional: it neither urged the jury to convict on a standard of proof lower than "beyond a reasonable doubt," nor permitted the jury to go outside the record of evidence to convict. ${ }^{232}$

The struggle of the courts of appeals in Vargas and Humphrey to determine the role of articulability in the reasonable-doubt instruction illustrates well the problems of the federal courts in examining the instructions, both on direct appeal and collateral review. Strictly in the light of the Supreme Court's elements of a forbidden instruction in Cage but the allowed instruction in Victor, it would seem that the Second Circuit and the dissenters of the Fifth Circuit are quite right to say that these instructions are within the limits of due process. On the other hand, the majority of the Fifth Circuit's Humphrey panel has a much clearer understanding of the problem of reasonable doubt than has been shown by the Supreme Court thus far.

The New Jersey Supreme Court, addressing the issue at about the same time as the Second and Fifth Circuits, although not considering the question as one of due process, upheld that state's long-standing rejection of the articulable doubt instruction. ${ }^{233}$ The court noted that "[j]urors may harbor a valid reasonable doubt even if they cannot explain the reason for the doubt."234

This observation by the New Jersey Supreme Court, and similar understandings by the Fifth Circuit, recognize the nature of a controversy seemingly unknown to the legion of scholars to consider the instruction as a whole. The articulable doubt instruction is widespread, accepted in at least a dozen jurisdictions. ${ }^{235}$ Even so, few scholars con-

232 Humphrey, 138 F.3d at 554 (Jones, J., dissenting).

233 State v. Medina, 685 A.2d 1242, 1246 (N.J. 1996) (citing State v. Vaszorich, 98 A.2d 299 (N.J. 1953)).

234 Id.

235 See, e.g., Johnson v. Alabama, 256 F.3d 1156 (11th Cir. 2001); United States v. Robbio, 186 F.3d 37 (1st Cir. 1999) (involving habeas appeal for federal conviction in Rhode Island); Simpson v. Matesanz, 175 F.3d 200 (1st Cir. 1999) (reviewing Massachusetts state instruction on habeas); United States v. Chester, No. 95-5446, No. 955510, 1997 U.S. App. LEXIS 23558 (4th Cir. Sept. 8, 1997) (unpublished) (involving direct appeal of federal conviction in South Carolina); United States v. Taylor, 997 F.2d 1551 (D.C. Cir. 1993); Harmon v. People, No. 97-CV-2539, 2001 U.S. Dist. LEXIS 20735 (E.D.N.Y. Dec. 11, 2001) (applying Keane to New York state instruction on habeas) (unpublished); United States v. Terlingo, No. 99-525-06, 99-525-07, 99-525-08, 2001 U.S. Dist. LEXIS 5709 (E.D. Pa. Apr. 30, 2001) (unpublished); Drayton v. Evatt, No. 2: 94-1608-23, 1998 U.S. Dist. LEXIS 22174 (D.S.C. Mar. 5, 1998) (involving habeas review of state conviction and order of death); People v. Sherman, No. 98CA2254, 2001 Colo. App. LEXIS 1674 (Oct. 11, 2001) (unpublished); State v. O’Neil, 789 A.2d 531 (Conn. App. Ct. 2001); People v. Scott, No. 216500, 2001 Mich. App. LEXIS 933 (May 29, 200ī) (unpublished); Washington v: Jones, No. 19778-6-III, 2002 Wạsh. App. LEXIS 28 (Jan. 8, 2002) (unpublished). 
sider it when examining the difficulties posed by reasonable doubt, being still distracted more by the largely moot questions posed by the moral certainty instruction. ${ }^{236}$

\section{Articulable Doubt and the Presumption of Innocence}

The deepest question is whether the articulable doubt instruction lowers the burden of proof the state must meet, or even reverses the burden of persuasion, to convict below the constitutional limits set in Winship. The Court, only five years after Winship, appeared to make explicit the long understood link between the burden of proof and the burden of persuasion, holding that the state must prove all of the elements of an indictment by a proof beyond a reasonable doubt. ${ }^{237}$ This case, however, did not concern itself with an articulable doubt instruction.

The First Circuit struck down an articulable doubt instruction in 1978, however, finding that the instruction reversed the burden of persuasion. ${ }^{238}$ Also, for this reason, Justices Marshall and Brennan dissented from two death case denials of habeas, in which Justice Marshall noted the conflict between this view by the First Circuit and other state courts and the view by South Carolina and other articulable-doubt states warranted certiorari to consider whether the articulable doubt standard would reverse the burden of persuasion. ${ }^{239}$ This

236 See, e.g., Corwin, supra note 5. Corwin inventories instructions based on moral certainty, the double inference, substantial doubt, and hesitation to act, but does not consider the doubt for which a reason can be given. Id. at 840-43. As noted above, Mulrine offers a rare consideration of the articulable doubt instruction, presenting it, however, solely as a matter of Canadian law. See Mulrine, supra note 5, at 216-17.

237 Mullaney v. Wilbur, 421 U.S. 684, 703-04 (1975). For an analysis of the relationship of reasonable doubt to the presumption of innocence in Mullaney, see Sundby, supra note 3 at 466-69.

238 Dunn v. Perrin, 570 F.2d 21 (1st Cir. 1978), cert. denied, 437 U.S. 910 (1978). The court's "definition of reasonable doubt was the exact inverse of what it should have been. Instead of requiring the government to prove guilt, it called upon petitioners to establish doubt in the jurors' minds. That is an inescapable violation of $I n$ re Winship)." Id. at 24 (citations omitted).

239 See Adams v. South Carolina, 464 U.S. 1023, 1026, nn.3-4 (1983) (Marshall, J., dissenting from denial of certiorari, with Brennan, J., joining) (citing Taylor v. Kentucky, 436 U.S. 478, 488 (1978); Pettine v. Territory of New Mexico, 201 F. 489, 495-97 (8th Gir. 1912); Laird v. State, 476 S.W.2d 811, 813 (Ark. 1972); State v. Derrico, 434 A.2d 356, 367-68 (Conn. 1980); Stirparo v. State, 287 A.2d 394 (Del. 1972); State v. Osbey, 517 P.2d 14I, 148 (Kan. 1973); State v. Davis, 482 S.W.2d 486, 489 (Mo. 1972); Frazier v. State, 100 S.W. 94, 102-03 (Tenn. 1907); Owens v. Commonwealth, 43 S.E.2d 895, 902 (Va. 1947); State v. McDonald, 571 P.2d 930, 940 (Wash. 1977)); see also Butler v. South Carolina, 459 U.S. 932, 932 (1982) (Marshall, J., dissenting from denial of certioriari). 
argument has been raised at least three times in recent years in the appellate courts, which have rejected it without analysis. ${ }^{240}$ It has yet to be addressed by the U.S. Supreme Court.

The Court's failing should not be surprising, given its continuing, historically incomplete consideration of the meaning of "reason," "doubt," and the role of certainty of guilt by the jury. The Court has yet to recognize that it has allowed a "reasonable" doubt to become synonymous with an articulable doubt, that a "reasonable doubt" is no longer a doubt held by a reasonable person, and that it is very far from a private judgment. As a result, the Court has left a sufficiently ambiguous direction to the lower courts that a requirement on jurors to articulate a doubt does not necessarily reduce the standard the Court has theoretically protected. The Vargas and the Humphrey dissenters are correctly following the lead of the current Court, even if the Humphrey majority is still correct in asserting the lowering of the standard from the early protections of reasonable doubt. By allowing the burden of proof to drift with changes in the meaning of reason, the Court tacitly has accepted lower burdens of proof.

\section{Twentieth and Twenty-First Centuries: Doubts About Reasonable Doubt}

By the end of the nineteenth century, "proof beyond a reasonable doubt" had become the ubiquitous standard for criminal trials in America. While there had been a considerable wrangle of cases attempting to refine this definition, there was still little concern that it

\footnotetext{
240 See State v. Medina, 685 A.2d 1242, 1246 (N.J. 1996), in which the charge that the instruction reverses the burden of persuasion was rejected but in the midst of a holding that the charge diminished the burden of proof; see also the tantalizing case People v. Jackson, 564 N.E.2d 652 (N.Y. 1990), in which the New York Court of Appeals refused to hear an argument that the articulable doubt instruction lowered the burden of persuasion, finding that the objection at trial in which, "[c]ounsel argued that such an instruction punished less articulate people on the jury, who might vote guilty 'because of the charge $* * *$ which says they should be able to articulate their reason'" did not preserve the issue for appeal of whether "the court's definition and illustration diluted the People's burden of proof by conveying a requirement that the doubting juror must give reasons and mus/ support those reasons with evidence." Id. at 653 .

The refusal to consider whether articulable doubt lowers the state's burden of persuasion concerned Judge Titone when the New York Court of Appeals again refused to address the issue in 1995. Writing in dissent, he argued that although the trial court correctly charged the jury with the state's burden of persuasion, an improper reasonable doubt charge containing an articulability standard, which they heard after it, diluted the effect of the persuasion charge. People v. Fields, 660 N.E.2d 1134, 1136-37 (N.Y. 1995) (Titone, J., dissenting).
} 
was not appropriate to the task of protecting innocent defendants from conviction. That complacency did not last as a universal matter.

In retrospect, we may discern five bases for increased criticism of the idea of reasonable doubt. The first is that, for all of its acceptance in the culture, it was unnecessary to the function of the juror: jurors did not need to be told how to exercise judgment. The second is its ambiguous nature: there are too many potential types of juror unreasonableness and too many types of unreasonable or reasonable doubt. The third is its culturally contingent limit: the idea of a common form of reason as an essential basis of judgment has become increasingly contested. The fourth is inherent in the idea of reasonableness as it has passed into the culture of language usage: the fine distinction between reason as a form of judgment and reason as a datum has largely disappeared.

The fifth reason is one that flows from the above four. One of the effects of the reasonable-doubt instruction, in the light of these four changes of perception, is to alter the presumption of innocence.

\section{A. Wigmoreans and the Instruction}

At the beginning of the twentieth century, even before the general adoption of articulability into the standard of proof beyond a reasonable doubt, concerns arose about the fitness of the formula as a basis for the jury's obligation. Although these concerns took numerous forms, they were, in sum, a recognition that the instruction was unnecessary, that a juror could employ more direct means of judging between sufficient certainty and sufficient doubt.

After all, in the late $1800 \mathrm{~s}$, the jury's obligation to find whether the state had proved "guilt beyond a reasonable doubt" was then still a relatively new invention and was not yet thought of as a monolith or as the false antique it has become. Rather, it was still in competition with the older obligation that the jury be convinced of the guilt of the defendant. For legal writers who were conversant with the theory of moral evidence and moral proof, "reasonable doubt" was still a particularly questionable modification of the fundamental obligation that the jury be morally certain of the guilt of the defendant. Moreover, as jurisdictions were increasingly beginning to use reasonable doubt, unmoored from its converse relationship to moral certainty, it became the sole point of definition in the juror's evaluation of the case. Such reliance was bound to cause concern, and it did.

John Henry Wigmore spilled notes across page after page of his vaunted treatise, detailing criticisms and concerns about reasonable 
doubt. ${ }^{241}$ His complaint about this "elusive and undefinable state of mind" was essentially that, despite the barrels of "ill-advised" precedent parsing carefully among the types of reasonableness that are acceptable and those that are not, the instructions were failures: "when anything more than a simple caution and a brief definition is given, the matter tends to become one of mere words, and the actual effect upon the jury, instead of being enlightenment, is rather confusion, or, at the least, a continued incomprehension." 242 The function of promoting a truth-finding function never entered into it. ${ }^{243}$

The primary effects of reasonable-doubt instructions, as Wigmore saw them, were to allow for legalistic quibbling and arguments on appeal. Moreover, the continuous attempts to resolve the meaning of reasonableness just made matters worse: "The effort to perpetuate and develop these elaborate unserviceable definitions is a useless one, and serves to-day chiefly to aid the purposes of the tactician. It should be abandoned."244

An ally of Wigmore's in his quest to overturn reasonable doubt proved to be William Trickett, a law professor at Dickinson, who in 1906 mounted a comprehensive attack on the idea of reasonable doubt, ${ }^{245}$ an attack wholly endorsed by Wigmore. ${ }^{246}$ Trickett noted that the juror's burden of ascertaining a reasonable doubt required the juror to perform two distinct functions. The juror "must have the doubt and be the critic of it." 247 To Trickett, this dual role was absurd:

What man ever entertained a doubt, which at the time. [sic] he believed to be unreasonable? To be convinced that a doubt of a fact is unreasonable, is to believe the fact. To tell a man that if he believes beyond a reasonable doubt, he must do so and so, is to tell him that if he believes beyond reasonably not believing, he is to do so and so, a valuable instruction surely! ${ }^{248}$

\footnotetext{
2415 WIGMORE, supra note $80, \S 2497$.

2425 id.

243 This very realist appraisal was certainly fitting for its time.

2445 id.

245 See William Trickett, Preponderance of Evidence and Reasonable Doubt, 10 Forum 75 (1906).

246 See John Henry Wigmore, Letter from Prof. Wigmore, 10 Forum 170 (1906). Wigmore exulted in Trickett's analysis and reprinted long excerpts from the article in later editions of his treatise. See 5 Wicmore, supra note 80, § 2497, at 468-69, 471-72. 247 Trickett, supra note 244 , at 81.

248 Id. at 81-82. Trickett continued in the same vein to criticize instructions that doubts should arise from the evidence, that they must not be fancied, nor conjured up, nor raised to escape rendering an unpleasant verdict, but must be honest, as would cloud a judgment, and dealt with as an important matter. Id. at 82-84.
} 
This criticism at first might appear to be based on Trickett's acceptance of a view that doubt is the opposite of certainty, yet this approach was rejected in criticizing Shaw's formulation in Webster, whose view seemingly required that all levels of belief below certainty be the same as doubt. ${ }^{249}$ Trickett deployed a different potential meaning of reasonable doubt as well, suggesting that one meaning of such instructions might be that the doubt might arise on reflection, disturbing an earlier conviction. ${ }^{250}$

In the end, Trickett found no comfort in any attempt to clarify "proof beyond a reasonable doubt." Rather, he reduced all of the accretions to Chief Justice Shaw's opinion, paring it down to a statement of remarkable clarity, which had an antiquity of which even the careful Professor Trickett seems to have been glibly unaware: "before convicting [someone] of a crime a juror should be morally certain that he committed it, and this conviction should be the result of a serious consideration of all the evidence." 251

Some of the problems Trickett identified are inevitable. A juror who must reach a judgment if it is beyond a reasonable doubt must be able to assess, somehow, what this means. A sincere effort to assess this meaning, whether or not it uses all of the additional terms thrown in from the bench, must require determining which doubts are and which are not reasonable. Whether the court falls back on tricks of articulation, as is often done, or just emphatically and enigmatically restates the standard, the juror is left to assess the sufficiency not of the doubt but of the reasonableness of the doubt.

One problem with the articulability instruction would become more obvious as it grew in frequency of use-its effect on the presumption of innocence. Wigmore's attack on the reasonable-doubt instruction as a confusion may also be seen in his concern for clarifying the state's burden of persuasion. Wigmore's powerful argument to solidify the presumption of innocence was borne of the same instinct. ${ }^{252}$ This argument bore fruit in the U.S. Supreme Court in

$249 I d$. at 85 . Despite Trickett's seeming unfamiliarity with the neo-Lockean idea of moral certainty, his result is, in fact, correct.

$250 \quad I d$. at 84.

251 Id. at 86.

252 See John H. Wigmore, The Presumption of Innocence in Criminal Cases, reprinted in James Bradley Thayer, a Preliminary Treatise on Evidence at the Common law 551,559 (Boston, Little, Brown, \& Co. 1898). Wigmore is carrying a banner held aloft by Greenleaf in his treatise. See Simon Greenileaf, A Treatise on the Law of EviDENCE 42-43 (Boston, Little, Brown \& Co. 1850). Wigmore's and Greenleaf's success is evident in Coffin v. Uniled States, 156 U.S. 432, 454 (1895) (citing 5 GreENLEAF, supra note 113). 
1895, when a right to a presumption of innocence in federal criminal cases was based on foundations in civil law, canon law, and the common law. ${ }^{253}$ In that opinion, Justice Douglass Edward White made clear that, despite the commentators who had implied the reasonabledoubt standard and presumption of innocence were synonymous, the two standards were quite different and independently pursued the same goal of ensuring the justice of the proceeding. ${ }^{254}$

\section{B. The Multiplicity of Meanings for Reasonable Doubt I: As Judgment of a Reasonable Juror}

Reasonable doubt, even when seen solely as doubt by reasonable jurors, suffers from an inevitable ambiguity. According to one view, such ambiguity has a benefit to the legal system, by allowing jurors to be flexible in determining the requisite degree of proof that the state must produce. ${ }^{255}$ Even so, the jurors are instructed that they do not have this license, by giving them an instruction on both the presumption of innocence and on the burden of proof itself. Further, when compared to the goal of accuracy, such a view fails to take into account the increased likelihood of a false conviction that accompanies trials for serious crimes. ${ }^{256}$

From the discussion in Parts II through IV above, it appears that there has been a broad evolution of the idea of reasonable doubt. This evolving notion of reasonable jurors is, at least at first blush, one in keeping with cultural expectations of justice. On closer inspection,

253 Coffin, 156 U.S. at 446-60. In 1877, the Court had implied that the government must always have the burden of persuasion, although it stopped short of announcing a defendant's right to an instruction on presumption of innocence. Lilienthal's Tobacco v. United States, 97 U.S. 237, 266 (1877) (citing, inter alia, Commonwealth v. Webster, 59 Mass. (5 Cush.) 305 (1850)).

The historical origins of the presumption itself are inventoried in the opinion. For a more comprehensive discussion, see Joseph C. Cascarelli, Presumption of Innocence and Natural Law: Machiavelli and Aquinas, 41 Aм. J. Juris. 229 (1996); and Fletcher, supra note 139, at 892 (providing a comparative and historical study). For discussion of the procedural developments of canon law that included not only the development of the presumption of innocence but also the closely related right against self-incrimination, see Kinneth Pennington, The Prince and the Law, 1200-1600: Sovereignty and Rights in the Western Legal Tradition 157-60 (1993); and R.H. Helmholz, Origins of the Privilege Against Self-Incrimination: The Role of the European Ius Commune, 65 N.Y.U. L. Rev. 962 (1990).

254 See Coffin, 156 U.S. at 460-61. White was then an Associate Justice; he was appointed Chief Justice in 1910.

255 See Erik Lillquist, Recasting Reasonable Doubt: Decision Theory and the Virtues of Variability, 36 U.C. Davis L. Rev. 85 (2002).

256 See Samuel R. Gross, The Risks of Death: Why Erroneous Convictions Are Common in Capital Cases, 44 Bufr. L. Rev. 469 (1996). 
however, differing conceptions of reason remain in play, which vary according to what exactly one is being reasonable about or who is being reasonable. Reasonable jurors, reasonable rules, and reasonable doubts each call to mind a different sense of the form of reason in play. Given that the earliest conceptions of reason in the juror's role was simply that a judgment must be reached by a reasonable decisionmaker, ${ }^{257}$ a brief inventory of this evolution of ideas of a reasonable juror might be in order.

Anachronistically, the reasonable juror was initially one steeped in local knowledge. For centuries, juries were drawn from small communities in which occurred the criminal act or lived the criminal defendant. Jurors were expected to know enough of the backgrounds of the participants to act as sources of evidence themselves. ${ }^{258}$ As jurors began to be drawn from a wider geography and as new rules of evidence excluded those with prior knowledge of the case from the jury, the jury's role became one only of judgment and not of witness. Thus, one of the earliest ways of speaking of juror reasonableness, the sense of fitness by local knowledge, became obsolete. Of course, this obsolescence is limited to the juror's role as an adjudicator of fact at arm's length. There is a continuing sense that a reasonable juror would be sufficiently familiar with the culture of the jurisdiction to comprehend and assess culturally contingent meanings of evidence in the case. More in keeping with the predicates to the understanding of reason in the seventeenth century, the "reasonable" juror possesses the tools of reason, being capable of the memory, imagination, understanding, and communication necessary for adult participation in the culture. More specifically to the reasonable person in the neo-Lockean sense of the eighteenth century, the reasonable juror is practical, capable of being satisfied by evidence to "moral certainty." Within the broader confines of the jury instructions of the early twentieth century, the reasonable juror is capable of deciding the facts on the basis of the evidence introduced into the case and is a sober person, who takes as important the cause before the court and the potential burden on the defendant and to society.

These shifts in the meaning of the reasonable juror correspond with the shifts in the manner of selection at the commencement of the trial, the process of voir dire. This process, as is well known, does not in fact concentrate on proving these elements of juror responsibility or fitness to the court. It is rather designed to assess venire mem-

257 See supra note 61 and accompanying text.

258 See BAKER, supra note 8 , at 88. 
bers through challenges to their fitness. This is especially the case in more serious criminal trials. ${ }^{259}$

An unreasonable juror can be depicted on a variety of grounds, which are largely the converse of the bases of reasonableness. Anachronistically, a "reasonable" juror would have no basis for judging the defendant or evidence from local knowledge. The unreasonable in the seventeenth-century view would be one who judges the defendant according to metaphysical or religious, or other non-practical bases. Correspondingly, the unreasonable juror of the eighteenth century might well have been a radical skeptic, an unadulterated Humean, who acted in the belief that there was no such thing as certainty. The current incarnation of unreasonable juror, in the broadest sense of the current instructions, is one who weighs the evidence with prejudice, giving significance or insignificance to evidence based on origins of the evidence related to class, race, gender, and other distinctions that are not related to the fit of the evidence with the issues of the case. In a narrower sense, the reasonable juror persists as an ideal, the "rational trier of fact" employed by appellate and habeas courts to measure the effect of an error in criminal cases. ${ }^{260}$

These general notions of reasonableness stand in some contrast to the more specific questions of reasonableness that have dogged the instruction of reason as a basis for doubt. The essential idea of the reasonable juror, as opposed to the reasonable doubt, has evolved to reflect altered social conventions. Yet, the degree to which one notion or another of what is reason is both indefinable and, potentially, in conflict.

\section{The Multiplicity of Meanings for Reasonable Doubt II: As a Modifier of Doubts}

A closely related basis for the ambiguity of reasonable doubt is the sheer number of ways in which it came to be, probably inevitably, understood at the bar. By 1897, the editors of the Decennial Digest were comfortable identifying not less than eighteen different formulæ for reasonable-doubt instructions, of which eleven were generic to all forms of proof and distinct in their definitions of the operation of

259 There are special limits on the beliefs of jurors qualified through voir dire to serve in capital crimes. It might not be unfair to say that jurors who hold such beliefs are unreasonable in the context of the capital jury, particularly as disqualification on these grounds are often for religious, moral, or sentimental beliefs that may not be analytically rational by all definitions of reason. That said, this sense of fitness for a jury seems rather distant from the notion of reasonableness.

260 For a paradigmatic approach of this test, see Judge William Barbour, Jr.'s opinion in Lockett v. Puckett, 980 F. Supp. 201, 227 (S.D. Miss. 1997). 
reason. ${ }^{261}$ Besides general admonitions and a continuing series of cases holding that reasonable doubt ought not or cannot be defined, these definitions amounted to the following:

1. Reasonable doubt is strong, real, substantial, or well-founded doubt.

2. Reasonable doubt is the opposite of moral certainty.

3. Reasonable doubt is the opposite of an abiding conviction in the defendant's guilt.

4. Reasonable doubt must be a conscientious belief.

5. Reasonable doubt must be a doubt or belief that can be held as men.

6. Reasonable doubt must be strong enough as a doubt that would influence an action in private affairs.

7. Reasonable doubt must be a doubt for which a reason can be given.

8. Proof beyond a reasonable doubt requires more than a suspicion or probability of guilt.

9. Reasonable doubt requires more than a probability or supposition of innocence.

10. Reasonable doubt requires more than a possibility of innocence.

11. Reasonable doubt can be based on any fact.

It is important in looking over these captions to recall that they are rarely exclusive of one another and that there has been throughout the century considerable disagreement among the states, and at different times in the same state, over the validity of any one definition. Furthermore, this eighteen-point schematic holding eleven forms of doubt was not meant even by West to suggest a talismanic meaning. Indeed, West's own mid-century "Words and Phrases" provided no less than thirty-one divisions to inventory different usages. ${ }^{262}$

\section{As a Contingent View of Judgment, Reasonableness Is Controversial}

Courts and their advisers continue to struggle both to define reasonable doubt and to define the contours of its place in jurors' in-

2616 West's American Digest 1897-1908, Decennial Edition 1111-28 (1908) (Criminal Law, Key Number 789). There were, of course, a wide range of specific instructions digested relating to the evidence of particular types of offense, as well as many cases, occupying several categories of the digest entry, determining the necessary or discretionary nature of the instruction. The West Company has maintained its eighteen-point division of this entry unto the present day. See, e.g., 6 WEST's AMERICAN Digest, Part 2, 1991-1996, Dechnnial EDition 1400-31 (1997).

262 See West's Words and Phrases 483-544 (1962). 
struction. The Florida and California instructions, which are reproduced in an appendix to this Article, are typical of the genre.

One response to this imprecision mounted by legal scholars under the influences of game theory and of law and economics in the 1970 s and 1980 s was to reduce the degree to which the juror was expected to rule on the case as a whole, by providing mathematical approaches to all of the subsidiary evidentiary questions. ${ }^{263}$ The result would be to reduce the questions of a case to components, none of which was prone to a holistic conception of reasonable certainty or reasonable doubt. While this new school of evidence attracted considerable initial controversy before moderating itself into less controversial statements, it has continued, ${ }^{264}$ despite powerful attacks against it by the likes of Larry Tribe, who have defended juror judgment as a holistic exercise, based in part on a juror's ability to determine guilt beyond a reasonable doubt. ${ }^{265}$

The recurrent attempts by the lawyers to employ definitions of reason as a basis for the laymen's doubt have two clear connotations, both of which are the basis for considerable suspicion for those who follow critical scholarship. First, in the words of Pierre Schlag, they are "language games about language games."266 The need to define limit $_{1}$ (doubt) by limit (reasonable) by limit $_{3}$ (grave) or limit (com-

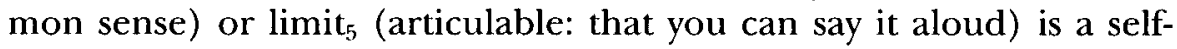
referential game. Once we move beyond one limit, the justifications for each limit are the other justifications. The very fact, however, that these justifications of limit 2 are so alluring to the lawyers in talking to the jury does not just illustrate the uselessness of limit through limit $_{5}$. They are also illustrative of the justificatory enterprise as a whole. In other words, the law is drawn to use reason to justify and control its delegation of power in the juror. But this justification must itself be justified, hence giving rise to the smoke and mirrors about what "reasonable" must mean here. These further justifications have no essential basis, and eventually the screen fades to black, with the law having

263 See, e.g., Gary S. Becker, Crime and Punishment: An Economic Approach, $76 \mathrm{~J}$. PoL. ECon. 169 (1968); Robert L. Birmingham, A Model of Criminal Process: Game Theory and Law, 56 Cornell L. Rev. 57 (1970); Kenneth S. Broun \& Douglas G. Kelly, Playing the Percentages and the Law of Evidence, 1970 ILL. L.F. 23 (1970); Michael O. Finkelstein \& William B. Fairley, A Bayesian Approach to Identification Evidence, 83 HARv. L. REv. 489 (1970); John Kaplan, Decision Theory and the Factfinding Process, 20 StaN. L. Rev. 1065 (1968). This approach was not truly novel in this age. See Note, Evidential Use of Mathematically Determined Probability, 28 HARv. L. Rev. 693, 695-96 (1915).

264 William Twining, The New Evidence Scholarship, 13 CARdozo L. Rev. 295 (1991).

265 Laurence H. Tribe, Trial By Mathematics: Precision and Ritual in the Legal Process, 84 Harv. L. REv. 1329, 1375 (1971).

266 Pierre Schlag, The Enchantment of Reason 86 (1998). 
made no better claim either for the juror to make decisions of guilt or for limits of reason on that power than the simple assertion that jurors have that power.

The second connotation is one of anachronism. The idea of reason, as a qualification for judgment or as a basis for knowledge, is not what it was three hundred years ago. If reason means anything in today's common culture, it is closest to the strain of cases demanding that what is reasonable is articulable. To be reasonable is to have a reason, and to have a reason is to be able to state a reason. ${ }^{267}$

Beyond the views of critical and economic scholars, the idea of articulability as a necessary condition for knowledge or judgment is inevitably beyond the limits of language and knowledge. ${ }^{268}$ Modern philosophy has presented many arguments against the seventeenthcentury view of knowledge and the idea that there is a common or even real sense of usage in which "reason" has a fixed meaning. ${ }^{269}$

267 This relationship between reasonableness and articulability echoes the arguments that one's view of reason is contingent on language made by Johann Georg Hamann and, especially, Johann Gottfried von Herder. Their arguments did not, however, require the utter reduction of reason to expression. See Isaiali Berlin, Vico and Herder: Two Studies in the History of Ideas 153-56 (1976) (noting Herder's rejection, under Hamann's influence, of disconnected theoretical frameworks).

268 The need for articulability in the exercise of judgment on the bench has already been mentioned. See supra text accompanying note 227 . The need for an appearance of concreteness, for the legitimacy that comes of an appearance of sturdy institutions is a strong lure in legal authors' descriptions of their task. See SCHLAc, supra note 266, at 120-40. There are more extreme views of the dangers of law's "irrational worship of rationality," particularly in the judicial assignment of reasons. See Paul F. Campos, Jurismania: The Madness of American Law (1998). This desire for articulability and concreteness is part of the price that must be paid for the law's rejection of Hume's skeptical view at the dawn of reasonable doubt. Other fields have moved on:

"In the study of ideas, it is necessary to remember that insistence on hardheaded clarity issues from sentimental feeling, as it were a mist, cloaking the perplexities of fact. Insistence on clarity at all costs is based on sheer superstition as to the mode in which human intelligence functions. Our reasonings grasp at straws for premises and float on gossamers for deductions."

Oswald Spengler, Meaning of Numbers, in 4 J.R. Newman, The World of Mathematics 2315 (1956) (quoting Alfred North Whitehead).

269 Perhaps the most powerful arguments remain the Romantic arguments that there are multiple conceptions of reason, each contingent on culture and language. These trace their origins from von Herder to Wittgenstein. See, e.g., Isalah BerLin, THE Roots of Romanticism (Henry Hardy ed., 1999). Beyond these nationalistic and linguistic arguments against a universal conception of reason, many twentieth-century philosophers were critical of most models of reason as failing to respond to some necessary element of subjectivism. See, e.g., John Dewey, The Quest for CerTainty: A Study of the Relation of Knowledge and Action (1929); Karl R. Popper, Objec- 
Some of these arguments flow from a resurgent strength in neoHumean views, and many more have developed from an increasingly sophisticated understanding of the mind. Some are simply pragmatic recognitions of practical limitations. ${ }^{270}$

At the least, these views recognize a considerable gap between reasons and reasonableness. ${ }^{271}$ The extreme view of these views, by historian of science Paul Feyerabend, is that rationalism in general

[h] as no identifiable content and reason no recognizable agenda over and above the principles of the party that happens to have appropriated its name. All it does now is to lend class to the general drive towards monotony. It is time to disengage Reason from this drive and, as it has been thoroughly compromised by the association, to bid it farewell. ${ }^{272}$

All of these concerns lie at the heart of the modern argument over the meaning and the content of the burden of proof beyond a reasonable doubt. They are inherent in the nature of the qualification itself.

\section{E. Articulable Reasonableness and the Presumption of Innocence}

From the very beginning, the reasonable-doubt instruction was intertwined with the presumption of innocence. ${ }^{273}$ The state held the burden of persuasion, who must prove or disprove guilt, and the burden of proof established whether the state had met its obligation, by setting how sufficiently the state had proved the defendant's guilt.

tive Knowledge: An Evolutionary Approach (rev. ed. 1979); Richard Rorty, PhiLOSOPHY AND THE MirRor OF NATURE (1979). Twentieth century philosophers have argued widely against over-reliance on reason. See, e.g., Paul Feyerabend, Against METHOD (2d ed. 1988).

270 See Glanville Williams, Textbook of Criminal Law 504 (2d ed. 1983) (observing that "a feeling in one's bones that is proved correct deserves respect regardless of the grounds of the feeling").

271 This recognition results largely from two arguments, that the sentiments or emotions are sufficiently causal in reasonable decisions for reasons to be sole causes in reasonable decisions, see, e.g., Virginia Black, Good Reasons and Reasonable Acts, $52 \mathrm{~J}$. Phil. 181-82 (1955) (elaborating on Bertrand Russell, Reason and Passion 48 THE Lis. TENER 495 (1952)) and that the complex employment of reasons in reasonable decisions obscures the role of any one or set of reasons. See, e.g., Jennifer Church, Reasonable Irationality, 96 MiND 354, 354 (1987) ("That there is some gap between having reasons and being reasonable is an epistemological commonplace; it follows from the recognition that being reasonable involves co-ordinating a variety of reasons.").

272 Paul Feyerabend, Farewell to Reason 13 (1987).

273 See Adams's argument in Rex $v$. Wemms, in 3 Lecal Papers of Adams, supra note 81 , at 243 . 
These two separate obligations are merged in the claim that the government must prove the defendant's guilt beyond a reasonable doubt. Therefore, even though the two standards are usually subject to separate instructions, when the Supreme Court adopted the reasonabledoubt standard as an interpretation of due process, it also enshrined the standard of a presumption of innocence as a constitutional requirement. ${ }^{274}$

Of course, the relationship between these standards is somewhat more complex. As the whole of a case grows more complex, and as certain defenses require proffers and rebuttals or counter-rebuttals, the effect of shifting burdens of persuasion on the underlying burden of proof may grow even more strained. ${ }^{275}$ These interrelationships are especially keen in the relationship between the separate instructions on reasonable doubt and the presumption of innocence, especially in the light of verdicts that must stand on circumstantial evidence to infer conclusions for which no direct evidence is available. ${ }^{276}$ Thus, the difficulty that jurors have in applying the reasonabledoubt standard has given rise to concerns that juror confusion regarding the burden of proof may affect juror application of the presumption of innocence. ${ }^{277}$

More specifically, federal and state judges have directly attacked the articulable doubt standard on the grounds that it reverses the presumption of innocence. ${ }^{278}$ This concern is highlighted in cases in which a holdout juror is required to explain that juror's point of view, after which the holdout accepts the majority's view of the evidence. ${ }^{279}$

274 See, e.g., Sundby, supra note 3, at 457.

275 See Barbara D. Underwood, The Thumb on the Scales of.Justice: Burdens of Persuasion in Criminal Cases, 68 YALE L.J. 1299 (1977).

276 See Dale A. Nance, Evidential Completeness and the Burden of Proof, 49 Hastincs L.J. 621 (1998); Charles R. Nesson, Reasonable Doubt and Permissive Inferences: The Value of Complexity, 92 HARv. L. Rev. 1187 (1979).

277 For an argument that the fact-intensive instruction is the only cure for the possibility that jury mistakes derived from the burden of proof will alter the presumption of innocence, see William S. Laufer, The Rhetoric of Innocence, 70 WASH. L. REv. 329 (1995).

278 See supra note 239 for the dissenting opinions of Justice Marshall, joined by Justice Brennan. For the dissenting opinion of New York Court of Appeals Judge Titone, see supra note 240.

279 See, e.g., Michigan v. Wiggins, No. 219564, 2001 Mich. App. LEXIS 2036 (Oct. 2, 2001) (unpublished). 


\section{Conclusions and Further Considerations}

\section{A. The Significance of Reasonable-Doubt Instructions Has Changed}

The chronicle above is one in which careful divisions by the likes of Locke and Greenleaf were built on an idea of reason as the nature of judgment. It was a complicated affair, in which there was considerable room for the reasonable but unexpressed and inexpressable.

During the nineteenth and twentieth centuries, however, the focus of something reasonable, particularly a reasonable thought, became increasingly simple, if not increasingly simplistic. First it became necessarily important. Then it became necessarily quantifiable. The love affair with reduction of the complex to the simple and the moral to the rational led to a linguistic drift that was rarely noticeable at any given time but profound in its ultimate effects.

Over time, the loss of our understanding of moral certainty and the increasing acceptance of articulability as a basis for reasonableness underscored a great shift in thinking about judgment by a juror. The courts have moved the jurors' goal from a vote for the state if the state can convince them of a fact to a vote for the state unless the defense can convince them of a certain type of doubt. This shift highlights two fundamental concerns regarding the role of the juror, and our beliefs about that role.

\section{B. The Change May Fundamentally Alter the Presumption of Innocence 280}

The shift appears to reverse the presumption of guilt. Although empirical research is necessary to determine whether this result occurs as easily as it seems, articulability instructions may work in the following way. A juror who would vote to convict may feel quite comfortable in the jury room in saying, "I think he's guilty," or at most, "The state has proved his guilt to me beyond a reasonable doubt." There is no apparent sense that such a juror is required to relate or even understand the state's case in detail.

A juror who would vote to acquit following an articulability instruction faces a different requirement. Because a reasonable doubt is one for which a reason must be given, this juror would seem to be obliged to say precisely what the doubt with the state's case is and why it is reasonable. A mere declaration that the juror is not convinced does not seem enough; it lacks the specificity suggested.

Of course, if the juror is not convinced, then according to the presumption of innocence, the juror is supposed to feel free to vote to

280 The central argument of this Part greatly benefited from remarks by participants at the University of Chicago Law and History Workshop in 2002. 
acquit. This supposition may be false in the light of the tremendous imbalance in favor of the state suggested by an articulable doubt instruction. The defendant-in the face of the modern reasonabledoubt instruction-must convince the jury of his innocence.

This effect has profound implications for our concept of the juror. The jury usually acts, particularly in criminal causes, through unanimous decisions, or at least through the collective will of the majority. Dynamite instructions and sequestrations require jurors to continue in their deliberations until, if at all possible, they reach a verdict. This deliberation, following judicial instruction in its management, is thought generally to give every juror an equal voice, and to make clear to all jurors that their role is to determine whether the state has proved its case.

Yet the burden to justify a reasonable doubt places an added barrier to the juror who would argue against the state, and it is a barrier that is both different in kind and degree from any obligation held by a juror who would vote with the state. This burden, created at the dawn of the reasonable-doubt instruction, although little appreciated for what it was, has simply grown more visible with the dumbing down of reasonable-doubt instructions over time.

It is possible, of course, to reform the instruction, to eliminate articulability instructions, and to leave each juror to contemplate what is reasonable about reasonable doubt. Other forms of reform are possible as well. Not the least would be to consider the problem of juror discretion, considered further below, in a greater light, and to allow public independent voting for verdicts, and to require conviction only for a unanimous vote. Or, requiring that those who would vote to convict must be convinced in a manner that can persuade others. Or allowing a juror who would vote to acquit to leave sequestration. These and many other changes might balance the load for those jurors who accept the defense's case. While none of these changes are advocated here, they may at least place in relief the effect of requiring acquittal-voting jurors to explain themselves.

\section{The Instruction Intrudes on Juror Discretion}

A further consideration that arises from this examination is that it highlights the very nature of the instruction as a limitation on the discretion of the juror. The instruction represents an attempt by the experts of the legal system to impose a series of limits on how the jurors will use their discretion. They are not to act independently but only as the law would have them act in their role. This particular limit on discretion is one that might be fundamentally immoral. 
The state is morally bound to give discretion to act when it holds an official responsible for an act: a particular responsibility requires conferring a concurrent power to exercise that responsibility. ${ }^{281}$ The nature of this discretion may be quite variable, and in the case of various types of officials the discretion may be bounded by limits including, for example, the scope of office of the nature of the task then before the official. Most importantly for the difference between professional legal officials and lay jurors, legal officials such as judges are often limited in their discretion by their ability to articulate and assign reasons for a decision.

The judge holds, of course, a fundamentally different form of discretion from that of the jury. The judge is bound to act in questions of the law itself, in a manner that allows review of the basis for the decision by other officials, as well as allowing other officials to apply these bases of decision to later questions. The juror's function is much more narrow, to use its best judgment to decide whether a criminal defendant did, as a matter of historical fact, do what has been alleged. ${ }^{282}$ The discretion needed for such a task is not to be constrained by obligations to convince others of the correctness of a decision, or to allow others to review it. The discretion needed is the independence necessary to reach a judgment that allows the juror to vote without reservations, without doubts, in the certainty that the juror has done all that can be done to give a fair verdict.

The juror has been given a task that demands only one power, the discretion to reach an independent judgment. ${ }^{283}$ A limitation on the forms of judgment the juror may apply to the evidence presented

281 This form of discretion is held both in the jury as a whole unit and in the jurors individually. A central notion of discretion is autonomy, and yet when the nature of a particular grant of discretion is to be vested in a unit, the autonomy is then of that unit. For a wide ranging model of legal discretion, albeit with an English edge, see D.J. Gallican, Discretionary Powers: A Legal Study of Official Disciretion (1986).

282 This difference in the form of legal authority is fundamental, with the authority of the decision of judges based on the fit with the rational rules of other legal officials but that of jurors being largely traditional and representational. See MAx Weber, Economy and Society 212-99 (1968).

283 Ed Rubin has made a persuasive case that discretion is a term often used by lawyers to reflect acts of policy making and that the term should be abandoned. Edward L. Rubin, Discretion and Its Discontents, 72 ChI-Kenr L. Rev. 1299, 1300 (1997). His model of discretion as an obsolete term for policymaking does not, however, apply to the jury, whose actions are not policy in the sense of actions that are to have general effect over time and among different people. The jury acts in each instance with effects limited solely to the defendant or defendants then before it. The discretion of the jury may, then, be an exception to Rubin's rule. 
in the trial is a limit on discretion, on the powers necessary to perform that task. Looking at the sum of the moral notions that might apply in the state's obligations to the juror, there is no question that the limit of juror independence is an immoral burden placed by state officials on the citizen-juror.

The moral problem of limited juror independence is heightened once the lens of the burdens on the juror is widened to encompass not only the decision itself but also the legal and social responsibility for the decision. Simply put, the juror is blamed for the law's errors. ${ }^{284}$

The successes and mistakes in investigation, arrest, and prosecution are placed before the jury. The jury alone must decide the facts of the case and the guilt of the accused. Once that decision is reached, the scrutiny that is made of it is very limited. A judge, whether in trial or on appeal, must set aside a jury verdict only if the judge believes the verdict is so outrageous that no reasonable jury could reach it. ${ }^{285}$ So long as the evidence presented in the case makes a decision a close call, a judge is unlikely to disturb a jury verdict. Thus, the harder the case, the more judicial reliance on the jury's decision there will likely be.

The jury is a scapegoat for the law. The juror immunizes the police, judge, and lawyers from mistakes prior to trial. Judges will not correct mistakes made by police or the lawyers or other judges unless the jury would likely have reached another decision if the mistake had not occurred. And, jurors immunize mistakes made after the trial. Judges need not much concern themselves that the condemned defendant is innocent, as that was a job for the jury. An actual error, the wrongful conviction of an innocent, is the fault of the jury.

One further moral attribute of the instruction's limit on juror independence deserves brief mention. There is a strong argument that the cross-cultural effect of suddenly moving a juror from outside the subculture of legal discourse into the realm of legal discourse contributes to juror confusion when confronted with legal discourse. Whether there is any meaning to a term like "reasonable doubt" in

284 For a passionate exposition on the requirements for this burden, see Sherman J. Clark, The Courage of Our Convictions, 97 MicH. L. Rev. 2381 (1999).

285 The courts apply the same limit on jury judgment to other realms of comparison to the jury's decision. The idea of judgment non obstante veredicto, or judgment notwithstanding the verdict, particularly in the criminal motion for judgment of acquittal, which asks the court to find the evidence presented by the state is "insufficient to sustain a conviction of such offense," turns on whether a reasonable jury can find guilt beyond a reasonable doubt. See Fed R. CRIM. P. 29; see also Jackson v. Virginia, 443 U.S. $307,318-19$ (1979). 
the law depends on the sub-culture of law, not on the culture outside. It is thus no surprise that there is such confusion over such a term that lawyers and judges will refuse to explain to confused juries. Regardless of whether lawyers understand what "reasonable doubt" means, there is a sense of deception in which jurors are told to work with tools they cannot understand. To so limit a person's judgment, even to common sense with such a limit, is not only to limit independence of judgment but to interject doubts as to the appropriate method of judging. To the degree a juror suffers such confusion, it undermines the very responsibility that the law demands the juror accept.

Given that the law places moral blame for errors made by legal officials on the juror, any limit on the juror's careful judgment that is required by law must be viewed with deep suspicion. The contradictory obligations of a legal barrier to independent judgment at a moment when the law demands independent judgment must be seen as an immoral burden upon the juror. There is a different problem of moral agency that arises from a jury limited in its independence by the legal officials themselves.

The idea that a layman is better suited for the job of assessing guilt than is a specialist is ancient and significant in the culture. That the independence of a citizen in this role might be limited by the specialists, and that the specialists might have a discreet thumb on the balance in that limitation, does not fit well with the cultural role of the jury as the triers of criminal fact and guilt, or even with the jury's role as scapegoat. That role, assigned to the non-specialist, is well described by an English essayist of some decades past. In considering the role, a very simple basis for a moral limit on officials is suggested; let the juror get on with the job without limits set by the lawyers on how the job will be done:

Now, it is a terrible business to mark a man out for the vengeance of men. But it is a terrible thing to which a man can grow accustomed, as he can to other terrible things; he can grow accustomed to the sun. And the horrible thing about all legal officials, even the best . . . is simply that they have got used to it. . . . .

Our civilization has decided, and very justly decided, that determining the guilt or innocence of men is a thing too important to be trusted to trained men. [When i] t wishes for light upon that awful matter, it asks men who know no more law than I know, but who can feel the things that I felt in the jury box. When it wants a library catalogued, or the solar system discovered, or any trifle of that kind, it uses up its specialists. But when it wishes anything done which is really serious, it collects twelve of the ordinary men standing 
around. The same thing was done, if I remember right, by the Founder of Christianity. 286

\section{There Is a Need for Further Empirical Research}

It is clear that the current standard of proof beyond a reasonable doubt has deep normative and descriptive frailties. There remains, however, an empirical gap of whether, in any one case, a jury is more likely to reach an historically accurate and morally justified verdict by one instruction or another. ${ }^{287}$ How much influence the instructions have in jury deliberations is difficult to measure, and how much of a

286 G.K. Chesterton, Tremendous Trifles 67-68 (1910).

287 There have been, of course, studies of juror comprehension and variation in the face of differing instructions. See, e.g., Theodore Eisenberg \& Martin T. Wells, Deadly Confusion: Juror Instructions in Capilal Cases, 79 CoRNELL. L. Rev. 1, 10-13 (1993) (describing Capital Jury Project survey of South Carolina jurors which found that jurors do not understand the nuances of the reasonable-doubt instruction, and the confusion may enhance a bias toward conviction and a death sentence) (on the CJP, see also William J. Bowers, The Capital Jury Project: Rationale, Design, and Preview of Early Findings, 70 Ind. L.J. 1043 (1995)); Stephen P. Garvey, et al., Correcting Deadly Confusion: Responding to Jury Inquiries in Capital Cases, 85 CoRnel. L. Rev. 627 (2000) (illustrating that clarification of instruction significantly aided juror comprehension in mock jury study); Geoffrey P. Kramer \& Dorean M. Koenig, Do Jurors Understand Criminal Jury Instructions? Analyzing the Results of the Michigan Juror Comprehension Project, 23 U. Mich J.L. Ref. 401, 414-16 (1990) (noting that Michigan jurors who were instructed on reasonable doubt were more likely to believe, correctly, that they can use their common sense but less likely to believe, correctly, that they may draw inferences from the evidence than were control jurors who were not instructed on reasonable doubt); Bradley Saxton, How Well Do Jurors Understand Jury Instructions? A Field Test Using Real Juries and Real Trials in Wyoming, 33 LANd \& Water L. Rev. 59 (1998) (revealing that between an eighth and a third of jurors failed to comprehend reasonable-doubt instruction). Similar results were reached in earlier studies. 'See HarrY Kaliven \& Hans Zeisel, The American Jury (1966); Phoebe C. Ellsworth, Are Tiuelue Hearls Better Than One?, 52 Law \& Contemp. Probs 205 (1989); William S. Geimer \& Jonathan Amsterdam, Why Jurors Vote Life or Death: Operative Factors in Ten Florida Denth Penally Cases, 15 Aм. J. CRIM. L. 1 (1988); Alan Reifman et al., Real Jurors' Understanding of the Law in Real Cases, 16 Law \& Hum. BeHav. 539 (1992); J. Alexander Tanford, The Law and Psychology of Juror Instmections, 69 NeB. L. REv. 71 (1990); David U. Strawn \& Raymond W. Buchanan, Jury Confusion: A Threat to Justice, 59 Judicature 478 (1976). In part, the failure of jurors to understand instructions perfectly is that they are crafted with a higher priority on accurate depiction of the law than on the law's clarity or comprehensibility. Joel D. Lieberman \& Bruce D. Sales, What Social Science Teaches Us About the Jury Instruction Process, 3 Psy., Public: PoL'y \& L. 589, 591 (1997). These results have been in line with the earliest of such projects. See A.P. Sealey et al., Juries and the Rules of Evidence, 1973 CRIM. L. Rev. 208, 215-19 (illustrating that jurors in rape case tended to vary verdict with varied instruction; jurors in theft case did not). Despite this volume of study, the author is aware of none that have been conducted to test the utility of the articulable doubt instruction, particularly none in 
difference one instruction might have over another must be a tremendously fact-intensive and context-sensitive endeavor.

The empirical doubt is greatest when asking whether a jury is more likely to arrive at a verdict that is in keeping with the historical facts, given the limitations of the availability, discovery, and presentation of evidence by the state. Given a presumption of innocence in the accused and an obligation of the state to prove criminal guilt, a crime that is poorly investigated or proved might well lead to a case in which the accused has committed the crime alleged but in which the jury is obliged to find the state has not proved the defendant's guilt. This danger, however, is one that simply cannot be minimized at the expense of lax standards of conviction without two immediate consequences: the higher likelihood of conviction of defendants who are innocent and the diminished moral justification of the punishment.

The holy grail of criminal law is to set its procedures so that all criminal defendants who have, in fact, committed crimes are punished for these crimes, but all those who are innocent but arrested are acquitted. Although there are those who believe that perfection in criminal law is dangerous to pursue, ${ }^{288}$ a standard of procedure in which this level of protection and inquisition would be achieved would be by that very fact justified; a truly more accurate criminal process would have both more convictions and fewer false convictions. Furthermore, all of the agents who act in accordance with such a marvelous standard would be acting with a sound basis that the retributive and social goals of the law are satisfied by their conduct.

comparison to other forms of instruction, such as certainty or an undefined standard of reasonable doubt.

288 See, e.g., Macklin Fleming, The Price of Perfect Justice: The Adverse Consequences of Current Lecal Doctrine on the Americin Courtroom (1974). 


\section{APPENDIX: \\ SAmple Model Jury InStructions 1999}

Federal Pattern Criminal Jury Instructions:

The government has the burden of proving the defendant guilty beyond a reasonable doubt. Some of you may have served as jurors in civil cases, where you were told that it is only necessary to prove that a fact is more likely true than not true. In criminal cases, the government's proof must be more powerful than that. It must be beyond a reasonable doubt.

Proof beyond a reasonable doubt is proof that leaves you firmly convinced of the defendant's guilt. There are very few things in this world that we know with absolute certainty, and in criminal cases the law does not require proof that overcomes every possible doubt. If, based on your consideration of the evidence, you are firmly convinced that the defendant is guilty of the crime charged, you must find him guilty. If on the other hand, you think there is a real possibility that he is not guilty, you must give him the benefit of the doubt and find him not guilty.

\section{California:}

A defendant in a criminal action is presumed to be innocent until the contrary is proved, and in case of a reasonable doubt whether [his] [her] guilt is satisfactorily shown, [he] [she] is entitled to a verdict of not guilty. This presumption places upon the People the burden of proving [him] [her] guilty beyond a reasonable doubt.

Reasonable doubt is defined as follows: It is not a mere possible doubt; because everything relating to human affairs is open to some possible or imaginary doubt. It is that state of the case which, after the entire comparison and consideration of all the evidence, leaves the minds of the jurors in that condition that they cannot say they feel an abiding conviction of the truth of the charge.

If you find [the] [a] defendant in this case guilty of murder of the first degree, you must then determine if [one or more of] the following special circumstance[s]: [is] [are] true or not true:

and ]. The People have the burden of proving the truth of a special circumstance. If you have a reasonable doubt as to whether a special circumstance is true, you must find it to be not true. [If you find beyond a reasonable doubt that the defendant was [a coconspirator] [or] [an aider or abettor] [either [the actual killer] [a co- conspirator] or an aider or abettor, but you are unable to decide which], then you must also find beyond a reasonable doubt that the 
defendant with intent to kill [participated as a co-conspirator with] [or] [aided [and abetted]] an actor in commission of the murder in the first degree, in order to find the special circumstance to be true.] [On the other hand, if you find beyond a reasonable doubt that the defendant was the actual killer, you need not find that the defendant intended to kill a human being in order to find the special circumstance to be true.] [You must decide separately as to each of the defendants the existence or nonexistence of each special circumstance alleged in this case. If you cannot agree as to all the defendants, but can agree as to one or more of them, you make your finding as to the one or more upon which you do agree.] [You must decide separately each special circumstance alleged in this case [as to each of the defendants]. If you cannot agree as to all of the special circumstances, but can agree as to one [or more of them], you must make your finding as to the one [or more] upon which you do agree.] In order to find a special circumstance alleged in this case to be true or untrue, you must agree unanimously. You will state your special finding as to whether the special circumstance is or is not true on the form that will be supplied.

(b) Death Penalty Trial

CALJIC 8.87 PENALTY TRIAL-OTHER CRIMINAL ACTIVITY-PROOF BEYOND A REASONABLE DOUBT

Evidence has been introduced for the purpose of showing that the defendant [ ] (name of defendant) has committed the following criminal [act[s]] [activity]: [ ] which involved (describe criminal [act[s]] [activity]) [the express or implied use of force or violence] [or] [the threat of force or violence]. Before a juror may consider any criminal [act[s]] [activity] as an aggravating circumstance in this case, a juror must first be satisfied beyond a reasonable doubt that the defendant [ (name of ] did in fact commit the criminal [act[s]] defendant) [activity]. A juror may not consider any evidence of any other criminal [act [s]] [activity] as an aggravating circumstance. It is not necessary for all jurors to agree. If any juror is convinced beyond a reasonable doubt that the criminal activity occurred, that juror may consider that activity as a fact in aggravation. If a juror is not so convinced, that juror must not consider that evidence for any purpose.

Florida:

[2.03] PLEA OF NOT GUILTY; REASONABLE DOUBT; AND BURDEN OF PROOF

The defendant has entered a plea of not guilty. This means you must presume or believe the defendant is innocent. The presumption 
stays with the defendant as to each material allegation in the Information through each stage of the trial until it has been overcome by the evidence to the exclusion of and beyond a reasonable doubt. To overcome the defendant's presumption of innocence, the State has the burden of proving the following two elements:

1. The crime with which the defendant is charged was committed.

2. The defendant is the person who committed the crime.

The defendant is not required to prove anything.

Whenever the words "reasonable doubt" are used you must consider the following:

A reasonable doubt is not a possible doubt, a speculative, imaginary or forced doubt. Such a doubt must not influence you to return a verdict of not guilty if you have an abiding conviction of guilt. On the other hand, if, after carefully considering, comparing and weighing all the evidence, there is not an abiding conviction of guilt, or, if, having a conviction, it is one which is not stable but one which wavers and vacillates, then the charge is not proved beyond every reasonable doubt and you must find the defendant not guilty because the doubt is reasonable. It is to the evidence introduced upon this trial, and to it alone, that you are to look for that proof. A reasonable doubt as to the guilt of the defendant may arise from the evidence, conflict in the evidence or the lack of evidence. If you have a reasonable doubt, you should find the defendant not guilty. If you have no reasonable doubt, you should find the defendant guilty.

[2.04] WEIGHING THE EVIDENCE

It is up to you to decide what evidence is reliable. You should use your common sense in deciding which is the best evidence, and which evidence should not be relied upon in considering your verdict. You may find some of the evidence not reliable, or less reliable than other evidence.

1. Did the witness seem to have an opportunity to see and know the things about which the witness testified?

2. Did the witness seem to have an accurate memory?

3. Was the witness honest and straightforward in answering the attorneys' questions?

4. Did the witness have some interest in how the case should be decided?

5. Does the witness' testimony agree with the other testimony and other evidence in the case?

You may rely on your own conclusion about the witness. A juror may believe or disbelieve all or any part of the evidence or the testimony of any witness. 


\section{[2.05] RULES FOR DELIBERATION}

These are some general rules that apply to your discussion. You must follow these rules in order to return a lawful verdict:

1. You must follow the law as it is set out in these instructions. If you fail to follow the law, your verdict will be a miscarriage of justice.

There is no reason for failing to follow the law in this case. All of us are depending upon you to make a wise and legal decision in this matter.

2. This case must be decided only upon the evidence that you have heard from the answers of the witnesses and have seen in the form of the exhibits in evidence and these instructions.

3. This case must not be decided for or against anyone because you feel sorry for anyone, or are angry at anyone.

4. Remember, the lawyers are not on trial. Your feelings about them should not influence your decision in this case.

5. Your duty is to determine if the defendant is guilty or not guilty, in accord with the law. It is the judge's job to determine what a proper sentence would be if the defendant is guilty.

6 . Whatever verdict you render must be unanimous, that is, each juror must agree to the same verdict.

Give 7 if applicable

7. It is entirely proper for a lawyer to talk to a witness about what testimony the witness would give if called to the courtroom. The witness should not be discredited by talking to a lawyer about his testimony.

8. Feelings of prejudice, bias or sympathy are not legally reasonable doubts and they should not be discussed by any of you in any way. Your verdict must be based on your views of the evidence, and on the law contained in these instructions. 
